\title{
Identificação, isolamento e caracterização funcional de células fibroblásticas reticulares derivadas de linfonodos humanos
}

Dissertação apresentada à Faculdade de Medicina da Universidade de São Paulo para obtenção do título de Mestre em Ciências

Programa de Alergia e Imunopatologia

Orientadora: Dra. Luciana Cavalheiro Marti

\section{SÃO PAULO}




\section{Identificação, isolamento e caracterização funcional de células fibroblásticas reticulares derivadas de linfonodos humanos}

Dissertação apresentada à Faculdade de Medicina da Universidade de São Paulo para obtenção do título de Mestre em Ciências

Programa de Alergia e Imunopatologia

Orientadora: Dra. Luciana Cavalheiro Marti

\section{SÃO PAULO}


Dados Internacionais de Catalogação na Publicação (CIP)

Preparada pela Biblioteca da

Faculdade de Medicina da Universidade de São Paulo

Creprodução autorizada pelo autor

Palomino, Diana Carolina Torres

Identificação, isolamento e caracterização funcional de células fibroblásticas reticulares derivadas de linfonodos humanos / Diana Carolina Torres Palomino. -São Paulo, 2016.

Dissertação(mestrado)--Faculdade de Medicina da Universidade de São Paulo. Programa de Alergia e Imunopatologia.

Orientadora: Luciana Cavalheiro Marti.

Descritores: 1.Células estromais 2.Fibroblastos 3.Linfonodos 4.Quimiocinas 5.Citocinas 6.Inflamação

USP/FM/DBD-332/16 
A minha mãe, Luz Palomino, por seu apoio, força, incentivo e por me impulsionar sempre a ser uma pessoa melhor em todos os aspectos da minha vida. 


\section{AGRADECIMENTOS}

A Deus por me amparar nos momentos difíceis, mostrar os caminhos nas horas incertas, me dar força interior para superar as dificuldades.

À minha família, a qual amo muito, pelo carinho, paciência e incentivo.

À minha orientadora, Dra. Luciana Marti, por acreditar em mim, me mostrar o caminho da ciência e contribuir para o meu crescimento profissional.

Às colegas do grupo de pesquisa e amigas Dra.Fernanda Agostini, Sabrina Nascimento, Maria Fernanda Marques, Laiz Camerão, Dra Camila de Almeida, Heliene Alvarenga e Suzana Benedito pela companhia e apoio durante esta etapa.

A meus amigos Sandra Sanchez, José Manuel Cóndor, Yuvi Aguedo e William Roldan pelas risadas, incentivo e amizade incondicional.

À fundação de amparo a Pesquisa do Estado de São Paulo FAPESP e ao Instituto UNIEMP pelo apoio financeiro para a realização do projeto. À Dra. Patricia Severino pela colaboração com o projeto.

Ao Instituto Israelita de Ensino e Pesquisa Albert Einstein IIEP, pela disponibilidade das ótimas instalações do laboratório. À Faculdade de Medicina da USP, especialmente o departamento de Alergia e Imunopatologia, pelo interesse no trabalho e apoio acadêmico para a realização do mestrado. Aos professores membros das bancas de qualificação e defesa, pelas contribuições ao trabalho. 


\section{SUMÁRIO}

Lista de figuras

Lista de tabelas

Lista de abreviaturas

Lista de símbolos

Resumo

Abstract

1. INTRODUÇÃO 14

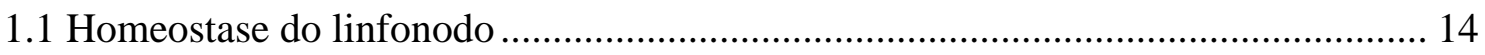

1.2 Populações de células não-hematopoéticas no linfonodo ..................................... 15

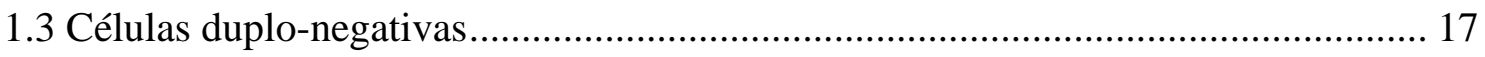

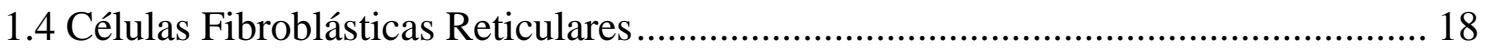

1.4.1 Produção de quimiocinas pelas células fibroblásticas reticulares...................... 22

1.4.2 Células fibroblásticas reticulares na indução de tolerância periférica ............... 26

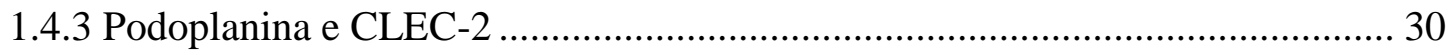

1.4.4 Interação entre as células reticulares fibroblásticas e células dendríticas........... 31

1.4.5 Remodelamento da rede de células fibroblásticas reticulares na expansão do

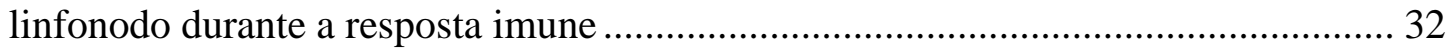

1.5 Expressão gênica das células fibroblásticas reticulares e células duplo-negativas na

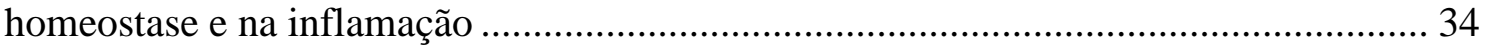

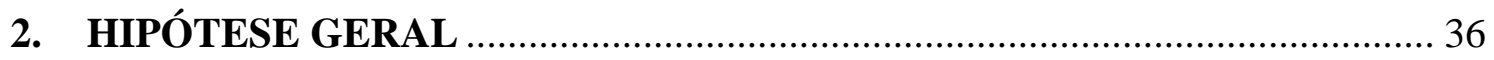

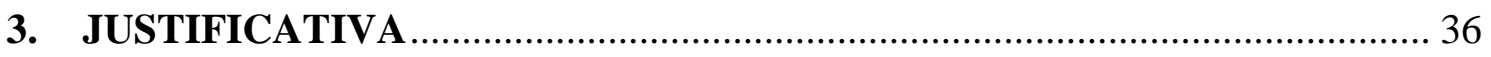

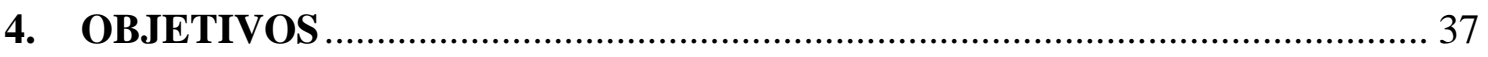

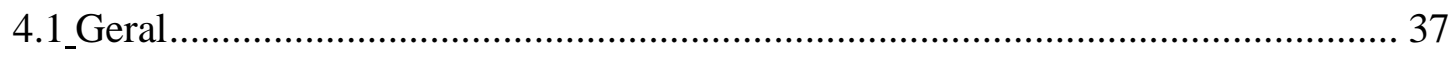

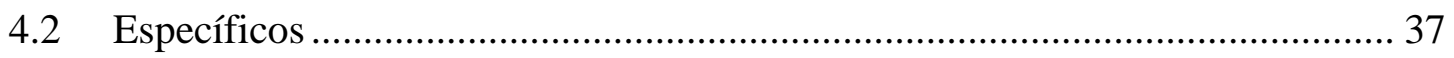




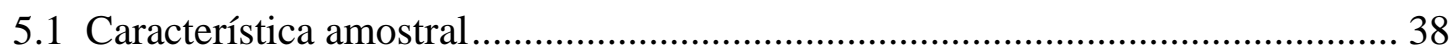

5.2 Análise anatomopatológica e imuno-histoquímica......................................... 38

5.3 Obtenção de células estromais e linfócitos a partir de linfonodos humanos ....... 39

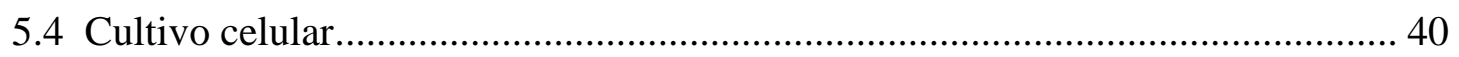

5.5 Caracterização imunofenotípica de FRCs e DNCs por citometria de fluxo ........ 40

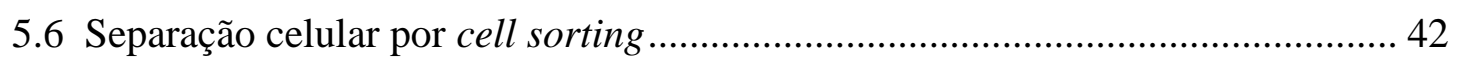

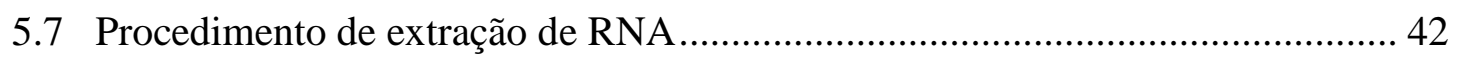

5.8 Avaliação da expressão gênica por microarranjos de DNA e validação dos

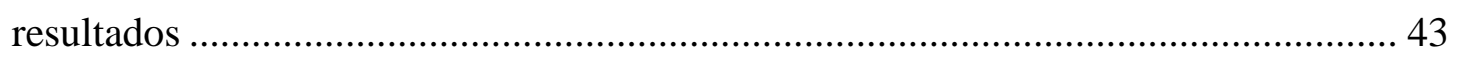

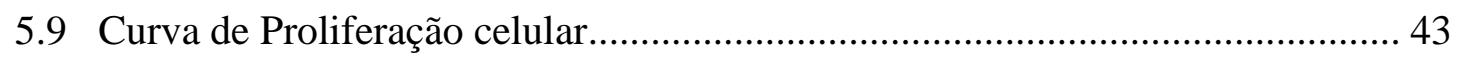

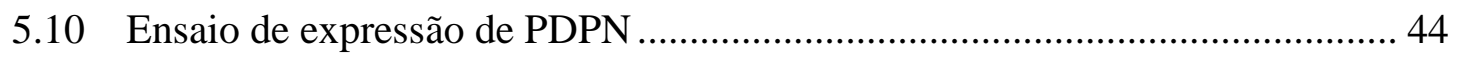

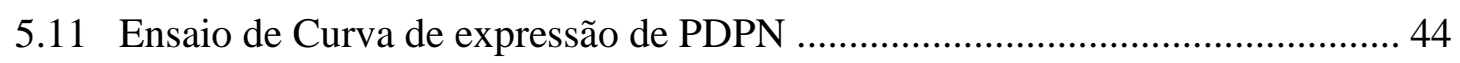

5.12 Detecção da produção de quimiocinas e citocinas por ELISA …..................... 45

5.13 Ensaio de expressão de proteínas de superfície celular por citometría de fluxo 45

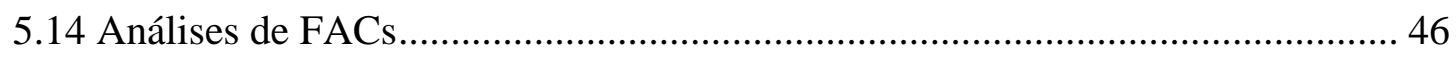

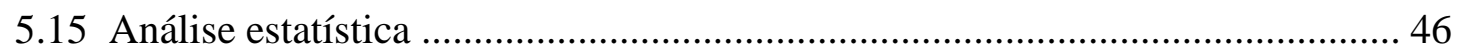

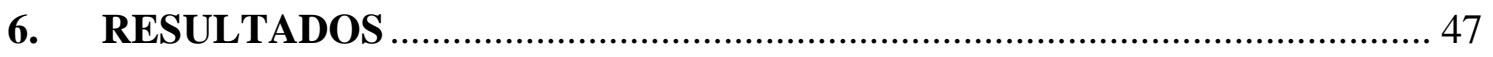

6.1 A análise anatomopatológica e imuno-histoquímica dos linfonodos evidenciou

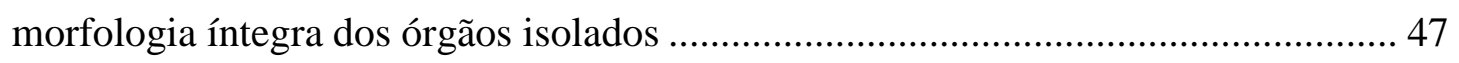

6.2 Caracterização imunofenotípica das células obtidas dos linfonodos humanos ... 49

6.3 A frequência de células estromais isoladas de linfonodos humanos varia segundo

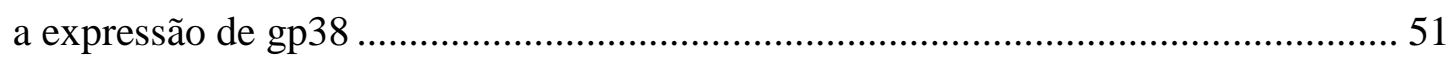

6.4 Separação das FRCs e DNCs por cell sorting ................................................. 53

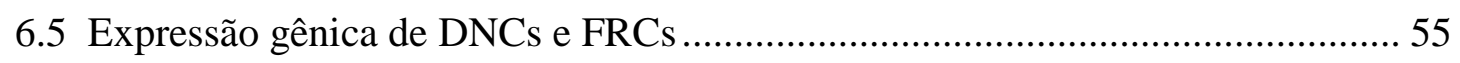

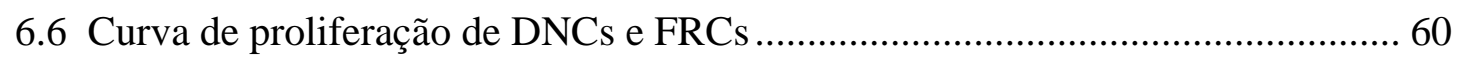


6.7 FRCs e DNCs aumentam a expressão de gp38 após tratamento com citocinas inflamatórias

6.8 Curva de expressão de gp38 nas FRCs 63

6.9 Estímulo inflamatório induz aumento na secreção de quimiocinas pelas FRCs e DNCs 64

6.10 Estímulo inflamatório contribui para secreção de citocinas pelas DNCs e FRCs 66

6.11 DNCs e FRCs alteram a expressão de moléculas de superfície envolvidas na resposta imune após estímulo inflamatório 68

7. DISCUSSÃO 73

8. CONCLUSÃO. 84

9. REFERÊNCIAS BIBLIOGRÁFICAS 85 APÊNDICES 


\section{LISTA DE FIGURAS}

Figura 1- Células não-hematopoéticas do linfonodo .25

Figura 2- Diferentes mecanismos de ação das FRCs murinas na ativação da resposta imune e indução de tolerância periférica .26

Figura 3- Analise histopatológica de linfonodos (LNs) humanos. .48

Figura 4- Dados representativos do perfil de expressão imunofenotípica das células obtidas do processamento de linfonodos humanos .50

Figura 5- Diferença na frequência de FRCs e DNCs nos linfonodos humanos. .52

Figura 6- Separação física de FRCs e DNCs (cell sorting) provenientes de LNs humanos. .54

Figura 7- Curva de proliferação de DNCs e FRCs .60

Figura 8- Expressão de gp38 após tratamento com IFN- $\gamma$ ou TNF- $\alpha+$ IL-1 $\beta$. .62

Figura 9- Curva de expressão de gp38 após estímulo inflamatório. .63

Figura 10- Secreção de quimiocinas pelas FRCs e DNCs após tratamento com IFN- $\gamma$ ou TNF- $\alpha+$ IL- $1 \beta$

Figura 11- Secreção de citocinas pelas FRCs e DNCs após tratamento com IFN- $\gamma$ ou TNF- $\alpha+$ IL-1 $\beta$.

Figura 12- Expressão de CD40 nas DNCs e FRCs após estímulo inflamatório com IFN$\gamma$ ou TNF- $\alpha+\mathrm{IL}-1 \beta$ .68

Figura 13- Expressão de CD83 nas DNCs e FRCs após estímulo inflamatório com IFN$\gamma$ ou TNF- $\alpha+$ IL- $1 \beta$

Figura 14- Expressão de HLA-ABC nas DNCs e FRCs após estímulo inflamatório com IFN- $\gamma$ ou TNF- $\alpha+$ IL- $1 \beta$ .70

Figura 15- Expressão de HLA-DR nas DNCs e FRCs após estímulo inflamatório com IFN- $\gamma$ ou TNF- $\alpha+$ IL- $1 \beta$ 
Figura 16- Expressão de CD274 nas DNCs e FRCs após estímulo inflamatório com IFN- $\gamma$

Figura 17- Perfil diferencial de superexpressão gênica e protéica de moléculas envolvidas na regulação positiva ou negativa da resposta imune após estímulo com IFN$\gamma$, nas DNCs e FRCs

Figura 18- Perfil diferencial de superexpressão gênica e protéica de moléculas envolvidas na regulação positiva ou negativa da resposta imune após estímulo com TNF- $\alpha+$ IL- $1 \beta$, nas DNCs e FRCs .84 


\section{LISTA DE TABELAS}

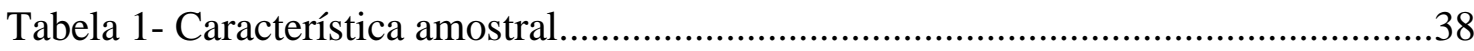

Tabela 2- Painel utilizado na identificação e caracterização das FRCs e DNCs.............41

Tabela 3- Anticorpos utilizados na imunofenotipagem das FRCs e DNCs....................41

Tabela 4- Anticorpos utilizados no ensaio de expressão de moléculas de superfície.....46

Tabela 5- Genes superexpressos em FRCs e DNCs tratadas com IFN- $\gamma$ comparadoas

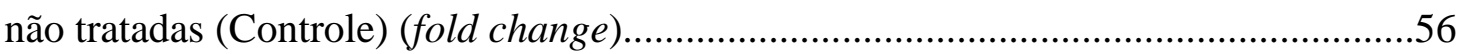

Tabela 6- Genes superexpressos em FRCs e DNCs tratadas com TNF- $\alpha+$ IL-1 $\beta$

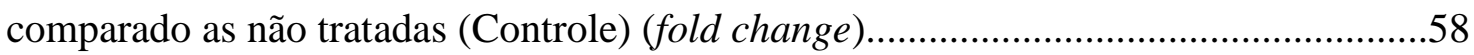

Tabela 7- Genes superexpressos relacionados à proliferação e controle da proliferação celular. .59 


\section{LISTA DE ABREVIATURAS}

AIRE: Gene regulador de autoimunidade (do inglês, Autoimmune regulator gene)

APC: Célula apresentadora de antígeno (do inglês, Antigen-presenting cell)

BEC: Célula endotelial sanguínea (do inglês, Blood endothelial cell)

CIITA: Transativador do MHC classe II

CLEC-2: Receptor de lecitina do tipo C (do inglês, C-type lectin-like receptor 2)

COX: Cicloxigenase (do inglês, Cyclooxygenase)

DC: Células dendríticas (do inglês, Dendritic cells)

DEAF1: Fator auto-regulatório epidérmico deformado (do inglês, Deformed epidermal autoregulatory fator 1)

DF1-VAR1: DF1 variante proveniente de um splicing alternativo (do inglês, Alternatively spliced variant in DF1)

DNC: Células estromais duplo negativas para gp38 e CD31 (do inglês, Double-negative cells)

ECM: Componentes da matriz extracelular (do inglês, Extracellular components matriz)

FDC: Células dendríticas foliculares (do inglês, Follicular dendritic cells)

FMO: Fluorescência menos uma(do inglês, Fluorescence minus one)

FRC: Célula reticular fibroblástica, (do inglês, Fibroblastic reticular cells)

HBSS: Solução balanceada de Hank (do inglês, Hank's balanced salt solution)

HE: Hematoxilina e eosina

HEV: Vênula do endotélio alto (do inglês, High vein endotelial)

IDO: Indolamina 2-3 desoxigenase (do inglês, Indoleamine 2, 3-dioxygenase)

IFN: Interferon

iNOS: Óxido nítrico sintase induzível (do inglês, Inducible nitric oxide synthase)

LEC: Célula endotelial linfática (do inglês, Lymphatic endothelial cell)

LN: Linfonodo ou nódulo linfático (do inglês, Lymph node)

LNSC: Células estromais de linfonodo

LTi: Células indutoras do tecido linfoide

LTo: Células organizadoras do tecido linfoide

Mc1: Meio de cultura celular 
Mc2: Meio de congelamento celular

MHC: Complexo principal de histocompatibilidade (do inglês, Major histocompatibility complex)

MIX: Solução enzimática

MRC: Células reticulares marginais (do inglês, Marginal reticular cells)

NK: Natural-killers

NO: Óxido nítrico (do inglês, Nitric oxide)

OLS: Órgãos linfóides secundários

P: Passagem celular

p75NGFR: Receptor do fator de crescimento neural p75 (do inglês, p75 Nerve growth factor receptor)

PBS: Tampão fosfato-salino (do inglês, Phosphate buffered saline)

PDGFRa: Receptor do fator de crescimento derivado de plaqueta (do inglês, Plateletderived growth factor receptor)

PD-L1: Ligante de morte programada 1

PDPN/gp38: Podoplanina (do inglês, Podoplanin)

PGE: Prostaglandina E2 (do inglês, Prostaglandin E2)

PTA: Antígenos de tecidos periféricos (do inglês, Peripheral tissues antigens)

SCS: Seio subcapsular (do inglês, Subcapsular sinus)

SP: Sangue periférico

S1P: Esfingosina 1 fosfatase

S1PR1: Receptor tipo1 de esfingosina 1 fosfatase

TCR: Receptor de célula T (do inglês, $T$ cell receptor)

TGF: Fator de crescimento transformante (do inglês, Transforming growth fator)

TH: Células T auxiliares (do inglês, T helper cells)

TLR: Receptor semelhante ao Toll (do inglês, Toll like receptor)

TNF: Fator de necrose tumoral (do inglês, Tumor Necrosis Fator)

TRCs: FRC da zona de células T

Treg: Células T reguladoras (do inglês, Regulatory $T$ cells)

TTG: Transglutaminase tecidual (do inglês, Tissue transglutaminase)

VEGF: Fator de crescimento endotelial vascular (do inglês, Vascular Endothelial Growth Factor) 


\section{LISTA DE SÍMBOLOS}

$\mu \mathrm{g}:$ Micrograma

$\boldsymbol{\mu L}:$ Microlitro

${ }^{\circ} \mathrm{C}$ : Grau Célsius

cm: Centímetro

g: Força Centrífuga Relativa

mL:Mililitros

ng: Nanograma 


\section{RESUMO}

\section{Palomino DCT. Identificação, isolamento e caracterização funcional de células}

fibroblásticas reticulares derivadas de linfonodos humanos [Dissertação]. São Paulo: Faculdade de Medicina, Universidade de São Paulo; 2016.

O linfonodo é um órgão linfoide secundário que apresenta uma arquitetura altamente organizada com diferentes compartimentos para tipos celulares específicos. Dentre as células estruturais que compõem este órgão, as células estromais como células fibroblásticas reticulares (FRCs) e células duplo negativas (DNCs) parecem ter papel importante na modulação da resposta imunológica e na tolerância periférica. As FRCs são caracterizadas pela expressão de podoplanina (gp38, PDPN) e localizam-se principalmente na zona de células $\mathrm{T}$, enquanto as DNCs (gp38) apresentam fenótipo, localização e função pouco descritos. Embora estas células tenham sido muito estudadas em modelos murinos os estudos sobre FRCs e DNCs humanas são escassos e, portanto nosso estudo deve contribuir para a compreensão da biologia e a função dessas células, podendo favorecer o conhecimento sobre a eficiência e as disfunções da resposta imune no linfonodo. Com esse intuito, isolamos e caracterizamos fenotípica e funcionalmente as FRCs e DNCs de linfonodos de pacientes com câncer, diverticulite e doadores de fígado. Nossos resultados mostraram a integridade e a distribuição celular no linfonodo. As células aderentes derivadas dos linfonodos estudados preecheram todos os critérios internacionais de caracterização de estroma, e, portanto, foram consideradas células estromais. Através da expressão de gp38 identificamos duas subpopulações de celulas estromais: FRCs $\left(\mathrm{gp} 38^{+}\right.$e $\left.\mathrm{CD} 31^{-}\right)$e $\mathrm{DNCs}\left(\mathrm{gp} 38^{-}\right.$e $\left.\mathrm{CD} 31^{-}\right)$e verificamos que as frequências destas células variam entre as amostras, sugerindo que a doença pode interferir na composição celular estromal dos linfonodos. As duas populações celulares foram estimuladas com citocinas inflamatórias como IFN- $\gamma$ ou TNF- $\alpha+$ IL-1 $1 \beta$ por 24 e 48 horas e avaliadas quanto à expressão gênica e proteica. Em condições homeostáticas, genes relacionados com a indução e controle da proliferação foram diferencialmente expressos nas FRCs e DNCs, este dado foi confirmado in vitro, uma vez que as FRCs apresentaram maior potencial proliferativo em relação às DNCs. O estímulo com IFN- $\gamma$ induziu aumento de expressão nas DNCs e FRCs para citocinas, quimiocinas, moléculas de histocompatibilidade e moléculas envolvidas na regulação da resposta imunológica. Em resposta ao estímulo com TNF- $\alpha+$ IL-1 $\beta$, observamos aumento na expressão de 
moléculas comuns ao estímulo com IFN- $\gamma$, entretanto, também observamos expressão de moléculas de citocinas, quimiocinas inflamatórias e moléculas de histocmpatibilidade especificamente relacionados a este sinal em ambas as populações. Em conjunto, nossos dados sugerem que DNCs e FRCs apresentam diferenças no perfil de resposta segundo os estímulos inflamatórios aos quais estão expostas, aumentando a expressão diferencial de moléculas envolvidas na regulação positiva e negativa da resposta imune.

Descritor: 1.Células estromais 2.Fibroblastos 3.Linfonodos 4.Quimiocinas 5. Citocinas 6. Inflamação 


\begin{abstract}
Palomino DCT. Identification, isolation and functional characterization of fibroblastic reticular cells derived from human lymph nodes [Dissertation]. São
\end{abstract} Paulo: "Faculdade de Medicina, Universidade de São Paulo"; 2016.

The lymph node is a secondary lymphoid organ that has a highly organized architecture with different compartments for specific cell types. Among the structural cells that comprise this organ, stromal fibroblastic reticular cells (FRCs) and double negative cells (DNCs) seems to play an important role in modulating the immune response and peripheral tolerance. FRCs are characterized by podoplanin (gp38, PDPN) expression and are located mainly in the T cell zone, while DNCs (gp38-) present phenotype, location and function not well described. Although these cells have been studied in murine models, studies on human FRCs and DNCs are limited and therefore our study should contribute to the understanding of biology and function of these cells and should promote knowledge of efficiency and disorders in the lymph node immune response. For this purpose, we have isolated and characterized phenotypic and functionally lymph nodes derived FRCs and DNCs from patients with cancer, diverticulitis and liver donors. Our results showed lymph node integrity and its cellular distribution. Adherent cells lymph nodes-derived fullfill the international criteria for stroma characterization, and therefore, they have been considered stromal cells. Using gp38 expression we were able to identify two stromal cells subpopulations: FRCs (gp38 ${ }^{+}$and $\left.\mathrm{CD} 31^{-}\right)$and DNCs (gp38- and $\mathrm{CD}^{-} 1^{-}$) and found that this cells frequency varies among samples, suggesting that the disease may interfere with lymph nodes stromal cell composition. These two cells populations were stimulated with inflammatory cytokines such as IFN- $\gamma$ or TNF- $\alpha$ + IL-1 $\beta$ for 24 and 48 hours and evaluated for gene and protein expression. In homeostatic conditions, genes involved in the induction and control of proliferation were differentially expressed by FRCs and DNCs, this data has been confirmed in vitro, since the FRCs showed higher proliferative potential compared to DNCs. IFN- $\gamma$ stimulation induced increase DNCs and FRCs expression for cytokines, chemokines, histocompatibility molecules and molecules involved in regulating the immune response.In response to TNF- $\alpha+$ IL- $1 \beta$ stimulation, we observed common molecules expressed by the IFN- $\gamma$ stimulation, however, we also observed expression of cytokines, chemokines and histocompatibility molecules specifically related to this signal in both 
cells populations. Together, our data suggest that DNCs and FRCs differ in the response profile according to inflammatory stimuli to which they are exposed, increasing the differential expression of molecules involved in the positive and negative regulation of immune response.

Descriptor: 1.Stromal cells 2.Fibroblasts 3.Lymph nodes 4.Chemokines 5.

Cytokines 6. Inflammation 


\section{INTRODUÇÃO}

\subsection{Homeostase do linfonodo}

A resposta imune em mamíferos é coordenada pelos órgãos linfóides secundários tais como baço, linfonodos e tecidos linfóides como as placas de Peyer e as tonsilas, os quais estão localizados estrategicamente no corpo. Nesses órgãos, as células do sistema imune adaptativo examinam com alta eficiência os antígenos drenados pela linfa (Cupedo et al, 2012).

Os linfonodos são órgãos linfóides encapsulados, com uma estrutura altamente organizada e complexa, composta por distintos compartimentos estruturais e celulares. Os linfonodos contêm todos os fatores necessários para o início da resposta imune, uma vez que estão localizados em pontos de convergência de vasos do sistema linfático, aumentando assim a possibilidade de encontro entre os antígenos e as células $\mathrm{T}$ ou $\mathrm{B}$ específicas a eles (Von Adrian e Mempel, 2003; Turley et al, 2010).

Estruturalmente o linfonodo é composto pelo córtex com localização mais periférica e uma medula interna. O córtex é composto por uma camada de células B organizadas em folículos linfoides, e áreas profundas, ou paracorticais, compostas principalmente por células $\mathrm{T}$ e células dendríticas (do inglês, dendritics cells DCs). A localização das células B e T nos linfonodos são reguladas de forma dinâmica pelo estado de ativação dessas células. Quando ativadas, as células B e T movem-se para a borda do folículo da zona de células $\mathrm{T}$, onde as células $\mathrm{T}$ podem fornecer sua função auxiliar às células B. Alguns folículos de células B incluem os centros germinativos, onde as células B sofrem intensa proliferação e diferenciação em plasmócitos. Portanto, a área de células B é a localização do desenvolvimento das respostas da imunidade humoral. Já no paracortex é o local onde os linfócitos T interagem com as DCs reconhecendo os antígenos que estas apresentam (Von Adrian e Mempel, 2003; Mueller e Germain, 2009; Cupedo et al, 2012).

Antígenos podem ser levados aos linfonodos drenantes através dos vasos linfáticos aferentes pelas células apresentadoras de antígeno (do inglês, antigenpresenting cell APC), como as DC, ou pela linfa quando solúveis. Imediatamente abaixo da cápsula do linfonodo, em uma área conhecida como seio subcapsular, estão os macrófagos que capturam antígenos solúveis e partículas que entram nos linfonodos 
drenantes de modo similar aos macrófagos da zona marginal do baço (Mueller e Germain, 2009).

Os linfócitos ingressam nos linfonodos principalmente através de vasos endoteliais especializados conhecidos como vênulas endoteliais altas (do inglês, high endothelial venules HEVs). A zona de células T contém tanto linfócitos T CD4+ como $\mathrm{CD}^{+}$, assim como DCs interagindo com uma rede de células estromais conhecidas como células fibroblásticas reticulares (do inglês, fibroblastic reticular cells FRCs). Nos folículos linfóides, as células B encontram-se junto com células dendríticas foliculares (do inglês, follicular dendritics cells FDCs). No seio subcapsular distinguese uma população de células estromais conhecidas como células reticulares marginais (do inglês, reticular marginal cells MRCs) (Katakai et al, 2008; Cupedo et al, 2012).

Após buscar antígenos cognatos durante várias horas no linfonodo, os linfócitos que não os encontram recebem sinais quimiotáticos que induzem a saída do linfonodo através dos vasos linfáticos eferentes. Os sinais de saída do linfonodo são dirigidos pela via de sinalização do receptor acoplado à proteína $\mathrm{G}, \mathrm{o}$ S1PR1, expresso nas células $\mathrm{B} \mathrm{e}$ $\mathrm{T}$, o qual se liga a S1P, expresso pelas células endoteliais do vaso linfático (Cyster e Schwab, 2012).

\subsection{Populações de células não-hematopoéticas no linfonodo}

No linfonodo são reconhecidas várias populações de células estromais e endoteliais, as quais não somente servem como suporte estrutural do órgão, como também participam da resposta imunológica e homeostase no LN. Tais células estão distribuídas em diferentes localizações dentro do órgão e podem ser identificadas por uma combinação de marcadores de superfície, principalmente pela expressão de marcadores como o CD31 e gp38 (podoplanina) (Link et al, 2007; Fletcher et al, 2010; Lukacs-Kornek et al,2011) Figura 1.

Quanto à localização, as células estromais, como as FRCs, podem ser encontradas na zona de células T, as FDCs nos folículos linfoides, as MRCs no seio subcapsular do linfonodo e dois grupos de células endoteliais, as células endoteliais sanguíneas (do inglês, blood endotelial cells BECs) e células endoteliais linfáticas (do inglês, lymphatic endotelial cells LECs) (Link et al, 2011; Alvarenga e Marti, 2014). 
Somente a expressão do gp38 (podoplanina) não é suficiente para identificar as FRCs murinas, pois este marcador também é expresso por FDCs e LECs. As LECs são diferenciadas pela expressão de CD21, CD31 e LYVE-1. As FDCs se diferem das FRCs pela sua localização e expressão de CD21, CD35, C4 (FDC-M2) e BP-3, Mfge8 (FDCM1), CD16, CD23, CD32. Porém, as FRCs e FDCs podem se assemelhar na expressão dos marcadores, CD54, CD106 e CD157 (Link et al, 2011; Luther et al, 2011; Sierget et al, 2011; Mueller e Germain, 2009).

As BECs expressam o marcador CD31 e são negativas para o gp38. Elas fazem parte dos vasos sanguíneos corticais e capilares incluindo as HEVs (Willard-Mack, 2006) por onde ingressam os linfócitos T e B para dentro do linfonodo. As HEVs apresentam moléculas de adesão, adressinas e quimiocinas, que facilitam o rolamento, adesão firme e posterior transmigração dos linfócitos (Cupedo et al, 2012).

As LECs estão presentes nos vasos linfáticos (Mueller e Germain, 2009; Luther et al, 2011) e estudos sugerem que de modo similar às FRCs, as LECs possuem capacidade de apresentar antígenos associados a tecidos periféricos (PTAs) aos linfócitos T naives (Cohen et al, 2010; Fletcher et al, 2010). Fenotipicamente expressam o CD44 homólogo ao receptor 1 de ácido hialurônico dos vasos endoteliais linfáticos (LYVEL), o marcador endotelial CD31 e se distinguem das FRCs por expressarem o CD31 (Fletcher et al, 2011). Adicionalmente, expressam várias moléculas de adesão e produzem a quimiocina CCL21, esta quimiocina está envolvida na entrada dos linfócitos nos sinusoides linfáticos. A entrada do linfócito no sinusoide linfático medular e cortical também requer o receptor tipo1 de esfigosina 1-fosfatase (S1P1) e seu ligante S1P, o qual é produzido e secretado na linfa por células não hematopoéticas, possivelmente por células endoteliais linfáticas (Mueller e Germain, 2009; Grigorova et al, 2009).

As FDCs formam uma densa rede nos folículos linfoides e participam da resposta humoral e produção de anticorpos pelas células B. FDCs podem expressar gp38, mas expressam outros marcadores como CR1/CD35, CD23 e ocasionalmente MAdCAM-1, diferenciando-se das FRCs. Além disso, produzem CXCL13, atraindo células B que expressam seu receptor CXCR5, facilitando a apresentação de antígenos opsonizados para os linfócitos B. Adicionalmente, mediante a produção de BAFF suporta a sobrevivência das células B (Cyster et al, 2010). 
As MRCs representam a terceira maior população de células estromais no linfonodo, estão localizadas no seio subcapsular e se caracterizam pelo fenótipo gp $38^{+}$ CD31-MAdCAM-1 ${ }^{+}$, produzem CXCL13 e BAFF, (Katakai et al, 2008; Katakai et al, 2012). Adicionalmente, não produzem CCL21, nem expressam CR1/CD35, o que permite distingui-las das FDCs (Katakai et al, 2008). As MRCs apresentam um importante papel no desenvolvimento do LN pela expressão de RANKL/TRANCE, uma citocina da família do TNF (Kong et al,1999). Estudos reportam que a contribuição das MRCs na produção de BAFF e CXCL13 sem presença de FRCs não é suficiente para manter a homeostase e resposta das células B (Chang e Turley, 2015). O papel das MRCs na organização e homeostase do LN ainda necessita de elucidação.

Uma população de células que não expressam o marcador gp38 nem o CD31 tem sido reconhecida no linfonodo e chamadas de células duplo negativas (DNCs) (Malhotra et al, 2012).

\subsection{Células duplo-negativas}

Estudos descrevem a existência de uma heterogênea população de células que não expressam o marcador gp38 e são negativas para o marcador endotelial CD31, e por isso são conhecidas como DNCs. São descritas como células similares aos pericitos com propriedades contráteis, os quais são encontrados próximos aos vasos medulares e corticais, constituindo 5-10\% das células estromais do linfonodo. Entretanto, embora as DNCs sejam similares aos pericitos, sua origem ainda não é totalmente conhecida, nem as regiões onde estão concentradas no linfonodo, seu fenótipo ou função (Link et al, 2007, Fletcher et al, 2010, Cohen et al, 2010)

Malhotra e colaboradores (2012) definiram as DNCs como células gp38- CD31CD45- CD44- porém Fletcher e colaboradores (2010) discordaram quanto à expressão de CD44, uma glicoproteína que liga ácido hialurônico, relatando que, assim como FRCs, DNCs também apresentam a expressão desse marcador. Outra proteína de superfície expressa em 50\% das DNCs, que poderia auxiliar na definição da localização e função desse grupo celular no LN, é uma integrina $\beta_{1} \alpha_{7}$ (ITGA7), à qual ligam as moléculas laminina-1, laminina-2 e laminina-4. Quando este marcador é expresso nas DNCs, estas células são nomeadas de pericitos integrina $\alpha_{7}$ (do inglês, integrin $\alpha_{7}$ pericytes, IAPs) (Malhotra et al, 2012). 
Adicionalmente, as DNCs expressam genes com função estrutural e de contratilidade, incluindo genes que codificam subtipos de moléculas de actina e cadeias de miosina (Malhotra et al, 2012).

Malhotra e colaboradores (2012) compararam, em camundongos, o perfil de expressão gênica global das diferentes populações de células não hematopoiéticas presentes no LN, e encontraram similaridade no perfil gênico entre as populações DNCs e FRCs comparadas às populações de células endoteliais, embora exista diferença considerável no fenótipo destas células. Tanto as FRCs como as DNCs podem expressar antígenos associados a tecidos periféricos no $\mathrm{LN}$, diferindo no repertório de antígenos expressos e no fator de transcrição que regula esta expressão. Nas FRCs o fator de transcrição regulado pelo gene DF1 (do inglês, deformed epidermal autoregulatoryfator 1 DEAF1) é responsável pela regulação, já nas DNCs o fator de transcrição regulador é o gene regulador de autoimunidade (do inglês, Autoimmune Regulator Gene, AIRE) (Malhotra et al, 2012, Fletcher et al, 2010).

Embora o conhecimento sobre as DNCs tenha evoluído, ainda são necessários mais estudos que possam esclarecer o papel funcional dessas células no LN em condições homeostáticas e durante o estabelecimento de uma resposta imune, uma vez que são encontradas em um órgão importante para o início da resposta imune e que parecem compartilhar similaridades com as FRCs, as quais parecem participar ativamente da resposta imune.

\subsection{Células Fibroblásticas Reticulares}

Recentemente, o desenvolvimento de novos métodos de microscopia eletrônica permitiu observar como as células imunes se movem dentro dos órgãos linfoides ex vivo ou in vivo. Tais métodos permitiram a observação dos movimentos dos linfócitos suportados por uma rede formada pelas FRCs e filamentos entre elas, revelando em detalhe a estrutura dessa rede (Von Adrian e Mempel, 2003; Mempel et al, 2004).

As FRCs são células de origem mesenquimal, podendo ser fusiformes, estreladas ou altamente alongadas dependendo da sua localização no linfonodo e são principalmente residentes da zona de células T no LN (Clark, 1962). As FRCs podem ser caracterizadas pela expressão de gp38 e pela secreção de proteínas da matriz 
extracelular como ERTR-7 e colágeno tipo I formando uma densa rede reticular (Bajenoff et al, 2006; Link et al, 2007; Turley et al, 2010; Malhotra et al, 2013).

Ainda não é completamente conhecida a origem das FRCs, embora evidências indiquem que, dentro do LN, as FRCs sejam derivadas das células organizadoras do tecido linfoide (do inglês, lymphoid tissue organizer cells LTo) (Fletcher et al, 2015), referindo duas populações de células: as células indutoras do tecido linfoide (do inglês, lymphoid tissue inducer cells LTi) e as células progenitoras mesenquimais. As células organizadoras do tecido linfoide (LTo) estão envolvidas no desenvolvimento do LN devido à secreção das moléculas necessárias para organogênese do LN incluindo LTbR, RANKL, CCL19, CCL21, CXCL13 e IL-7 (Chai et al, 2013).

Existe a hipótese de que durante a embriogênese, a produção de ácido retinóico por neurônios pode estimular as células mesenquimais precursoras do $\mathrm{LN}$, das quais derivam as FRCs, a sintetizarem CXCL13, cuja sinalização induz a formação da estrutura do LN pelo recrutamento das células LTi (Van de Pavert et al, 2009; Brendolan and Caamaño, 2012; Fletcher et al, 2015). Estudos recentes sugerem que préadipócitos sejam uma segunda fonte de células precursoras mesenquimais, pois podem ser recrutados do tecido adiposo adjacente até o LN de maneira dependente de LT $\beta R$ e CXCR4. No LN, os pré-adipócitos se diferenciam em células LTo CXCL13 ${ }^{+}$. Desse modo, possivelmente as duas fontes de células mesenquimais precursoras, tanto as locais quanto as derivadas do tecido adiposo, contribuem para a formação do estroma do LN (Bénézech et al, 2012; Fletcher et al, 2015).

As FRCs, em murinos, atuam no desenvolvimento dos órgãos linfoides secundários como baço e LNs, mediante a participação de várias citocinas da superfamília do TNF, como linfotoxinas $\alpha$ e $\beta$, LIGHT, TNF, junto com seus respectivos receptores (Koni et al, 1997). Estudos feitos em camundongos deficientes de linfotoxina- $\alpha$, apresentaram alteração no desenvolvimento das placas de Peyer, linfonodos, FDCs e centros germinativos (De togni et al, 2014). Adicionalmente, a ausência de linfotoxina- $\beta$ também contribuiu para um desenvolvimento desorganizado do baço (Cyster et al, 2014).

Além disso, a ausência de TNF- $\alpha$ pode afetar negativamente tanto o desenvolvimento das FRCs quanto a produção das quimiocinas CCL21 e CCL19, 
diminuindo o recrutamento das células T no baço, mas não nos linfonodos (Zhao et al, 2015).

Link e colaboradores (2007) descrevem quatro subtipos de FRCs em LNs de roedores, segundo sua localização: FRC na zona de células T (TRCs), FRCs próximas e ao redor dos canais condutores, FRCs revestindo o seio subcapsular e FRCs próximas aos vasos sanguíneos (pericitos) (Link et al, 2007). Adicionalmente, existe ainda outro subtipo de FRC localizado logo abaixo da cápsula do LN, as MRCs. Diferente das FRCs, as MRCs expressam CXCL13, MAdCAM-1 e altos níveis de RANK-L (Mueller e Germain, 2009; Luther et al, 2011; Hess et al, 2012).

Além dos subtipos de FRC classificados segundo sua localização, outros dois marcadores foram descritos em primatas capazes de subclassificar as FRCs, o receptor do fator de crescimento neural p75 (do inglês Nerve Growth Factor Receptor, p75NGFR) e a transglutaminase tecidual (do inglês Tissue transglutaminase, TTG). FRCs são positivas para p75NGFR, um membro da família do receptor de fator de necrose tumoral (do inglês Tumor necrosis fator, TNF), e todas as subpopulações de FRCs descritas segundo sua localização são positivas para TTG, uma enzima envolvida em vários processos fisiológicos e patológicos, como apoptose de linfócitos e outros tipos celulares, e a ativação de citocinas pró-inflamatórias. Embora a expressão de TTG esteja correlacionada aos subtipos de FRCs classificados segundo sua localização, a expressão de p75NGFR não foi reportada como subtipo específico (Steele et al, 2009).

Thomazy e colaboradores (2003) utilizaram a TTG, que previamente foi descrita como citocina e molécula induzível por retinóides, para evidenciar mudanças no estado da rede reticular de LNs normais em comparação aos neoplásicos. Existem algumas condições em que a rede de FRC fica aberta, permitindo a alta circulação de células e solutos ao redor do folículo, sendo este estado correlacionado com o pico de reações no centro germinativo e aumento de expressão de TTG. Outras vezes, essa rede fica fechada, limitando a migração de células do SCS, e a expressão de TTG fica restrita às células do SCS. O padrão de TTG encontrado no estroma de diferentes tipos de linfomas sugere que ocorra a alteração destes padrões dinâmicos na maioria dos tipos tumorais (Thomazy et al, 2003).

As FRCs no LN mantêm contato entre si e com outros tipos celulares como linfócitos, linfoblastos, células plasmáticas, DCs e FDCs. Quando as FRCs estão em 
contato, suas membranas citoplasmáticas apresentam um espaço de aproximadamente 20nm, formando canais intercelulares conhecidos como redes de fibras reticulares responsáveis pelo transporte de diferentes moléculas solúveis, como antígenos, desde os vasos linfáticos aferentes até a área de células T no LN. Tal organização contribui para que esses antígenos sejam capturados pelas DCs residentes no LN (Crivellato e Mallardi, 1997; Alvarenga e Marti, 2014).

Cremasco e colaboradores (2014) mostraram, em camundongos, que a depleção de FRCs resultou em alteração da homeostase e do compartimento de células $\mathrm{T}$ no linfonodo, com consequências na ativação, expansão e função dos linfócitos T efetores, embora o LN não tenha sofrido perda imediata da estrutura de seus condutos. Tais dados sugerem que as FRCs são essenciais para a resposta mediada por linfócitos T, mas não para a manutenção em curto prazo do sistema de canais no LN. A ausência de FRCs também levou a redução significativa na viabilidade de células B e alteração na organização dos folículos linfoides, afetando a resposta imune humoral dependente e independente de células T (Cremasco et al, 2014).

Entretanto, durante o desenvolvimento do LN, a IL-7 é produzida pelas células precursoras mesenquimais (Roozendaal and Mebius, 2011). A IL-7 derivada dessas células promove a sobrevivência das células LTi, as quais participam da formação do microambiente do LN, dependente do receptor de linfotoxina $\beta$ (Chappaz e Finke, 2010).

A IL-7 é uma citocina importante que controla o desenvolvimento e ativação de diferentes células imunes, assim como a homeostase das células T naives (Link et al, 2007; Kang et al, 2012). Dentro dos órgãos linfoides secundários, a IL-7 promove sinais antiapoptóticos e proliferativos para as células T, e tem função essencial na homeostase de células $\mathrm{T}$ periféricas (Mackall et al, 2011). A ausência de IL-7, por deficiência genética ou neutralização mediada por anticorpo, induz uma gradual diminuição de células T periféricas em aproximadamente 3 semanas. Em contraste, a superexpressão de IL-7 em camundongos transgênicos aumenta substancialmente a quantidade de células T naives na periferia (Surch e Sprent, 2008).

Link e colaboradores (2007) reportaram a produção de IL-7 em linfonodos de camundongos pelas FRCs na zona de células T. Essas células também foram capazes de 
produzir quimiocinas como CCL19 e CCL21 em modelos murinos, as quais podem ter papel similar à IL-7 no suporte e sobrevivência das células T naives in vitro. Embora, exista a referência de que CCL19 tenha a função de regular a homeostase das células T, tal função não pode ser compensada pela secreção de CCL21, que apresenta potencial inferior à da IL-7 na regulação da homeostase (Link et al, 2007). A síntese de IL-7 também tem sido detectada nas LECs, sugerindo que essa produção influencie a adaptação estrutural do microambiente do LN durante o remodelamento induzido, por exemplo, durante uma resposta antiviral (Onder et al, 2012).

\subsubsection{Produção de quimiocinas pelas células fibroblásticas reticulares}

As quimiocinas (citocinas quimiotáticas) são pequenas proteínas solúveis que participam no controle da migração e posicionamento das células tanto na homeostase como durante a resposta imune celular e humoral, além de contribuir na patogênese de uma variedade de doenças (Zlotnik et al, 2011; Griffith et al, 2014).

As quimiocinas constituem uma superfamília de 50 ligantes endógenos em humanos e camundongos, que se ligam aos receptores de sinalização intracelular de sete domínios transmembrana associados à proteína $\mathrm{G}$, e podem ser divididas em quatro subfamílias: C, CC, CXC e CX3C, segundo o número e espaçamento dos aminoácidos existentes nos dois primeiros resíduos de cisteína da extremidade $\mathrm{N}$-terminal. Podendo ser também classificadas, funcionalmente, em quimiocinas inflamatórias e homeostáticas (Charo et al, 2006).

As quimiocinas inflamatórias são expressas por células residentes e infiltradas, após estimulação com citocinas pró-inflamatórias ou durante o contato com agentes patogênicos, e são especializadas no recrutamento de células efetoras como monócitos, granulócitos e linfócitos $\mathrm{T}$ efetores. Quimiocinas homeostáticas são expressas constitutivamente em tecidos linfoides e não linfoides por tipos específicos de células, além de estarem envolvidas no controle do processo de organogênese, manutenção da homeostase e no direcionamento das células circulantes através dos tecidos (Moser e Loetscher, 2001; Griffith et al, 2014).

As interações entre os diferentes subtipos de células do sistema imune, nos órgãos linfoides secundários, são requeridas para o bom funcionamento da resposta 
imune. Essa dinâmica depende da capacidade dessas células de migrar ativamente através desses órgãos (Förster et al, 2008).

Após seleção e maturação no timo, os linfócitos $\mathrm{T}$ naives continuamente circulam entre a periferia e os órgãos linfoides secundários como o LN. Os linfócitos entram no LN através das HEVs, de modo dependente de sinais de quimiocinas e de interações de selectinas e integrinas, até a zona de células $\mathrm{T}$ onde examinam a presença de antígenos ligados às moléculas do MHC, apresentados pelas APCs como as DCs. Por outro lado, os antígenos solúveis e as DCs transportando antígenos são levados através da linfa e ingressam no LN pelos vasos linfáticos aferentes também guiados por sinais de quimiocinas (Miyasaka e Tanaka, 2004, Mueller e Ahmed, 2008).

Receptores de quimiocinas são essenciais para a entrada e posicionamento dos linfócitos naives e DCs, no LN e no baço. Dentre eles podemos destacar o CCR7 expresso em vários tipos celulares incluindo linfócitos T e DCs, ao qual se ligam as quimiocinas CCL19 e CCL21, (Bromley et al, 2008; Mueller et al, 2013; Griffith et al, 2014). Na ausência de sinais de retenção pelo CCR7, as células T migram através de gradientes de esfingosine-1-fostato (do inglês, Sphingosine-1-phosphate S1P), o qual induz a saída das células fora do LN, pelos dos vasos linfáticos eferentes (Masopust e Schenkel, 2013).

O receptor de quimiocinas CXCR4 e seu ligante CXCL12 também promovem a entrada dos linfócitos T naives dentro do LN (Griffith et al, 2014), porém, camundongos deficientes de CXCR4 exibem defeitos no homing de células $\mathrm{T}$ naives somente na ausência do CCR7, sugerindo que o papel do CXCR4 seja menor comparado ao CCR7 (Okada et al, 2002).

Adicionalmente a CCL19, CCL21 e CXCL12 ativam a integrina LFA-1 na superfície das HEVs, que se liga fortemente às moléculas ICAM-1 e ICAM-3 expressas em células T, auxiliando a entrada dessas células no LN (Shamri et al, 2005).

Em contrapartida, nos folículos de células B do LN, a rede de FDCs produz CXCL13 o qual promove a localização homeostática dos linfócitos B devido à ligação ao seu receptor CXCR5. (Mueller et al, 2013; Bromley et al, 2008; Mueller e Germain, 2009; Griffith et al, 2014). 
As LECs, BECs, FDCs e FRCs produzem muitas das quimiocinas presentes no LN. As FRCs, na zona de células T, no baço e LN rodeiam as HEVs formando uma densa rede junto aos linfócitos. Estas células no LN produzem fibras reticulares ricas em colágeno que formam canais pelos quais são transportadas moléculas de baixo peso molecular como antígenos solúveis, citocinas e quimiocinas até a zona de células $\mathrm{T}$ (Mueller e Germain, 2009).

Evidências sugerem que a migração dos linfócitos $\mathrm{T}$ e DCs através do LN de camundongos é suportada pelas FRCs na zona de células T (Bajenoff et al, 2006), uma vez que expressam constitutivamente os ligantes do CCR7: as quimiocinas CCL21 e CCL19 (Luther et al, 2000; Mueller e Germain, 2009). Similar às FRCs, as DNCs podem contribuir com a produção de quimiocinas. Além dessas células, as células endoteliais expressam pequenas quantidades de mRNA para CCL19, sendo as LECs as únicas que expressam transcritos para CCL20 (Malhotra et al, 2013).

As FRCs também transcrevem CXCL13, de modo considerável e similar às MRCs, que são conhecidas por expressarem o marcador MAdCAM-1. Adicionalmente, as FRCs transcrevem outros tipos de quimiocinas como CCL2 e CCL7 que podem facilitar o recrutamento de células T de memória e DCs (Malhotra et al, 2013). 
A
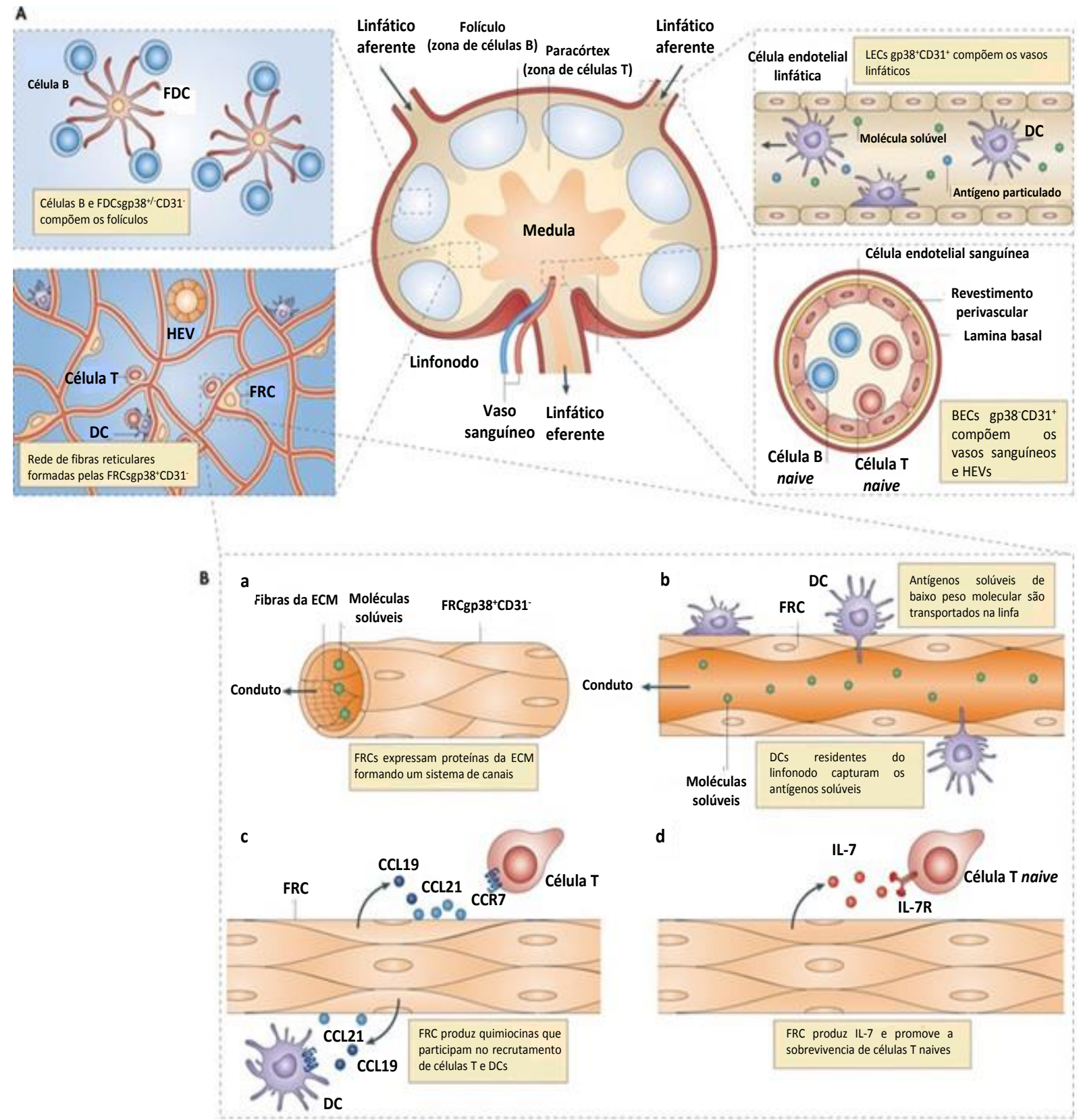

Figura 1. Células não-hematopoéticas do Linfonodo. A. Localização das células não hematopoéticas no linfonodo. FRC são encountradas principalmente na zona de células $\mathrm{T}$, auxiliando no soporte estrutural para a interação entre células T e DCs. FDCs junto às células B organizam o folículo linfoide. LECs compõem os vasos linfáticos aferentes e eferentes. BECs formam estruturas especializadas conhecidas como HEVs. B. Diversas funções das FRCs. a) FRC produz proteinas da matriz extracelular (ECM) e formam o sistema de canais dentro do linfonodo. b) DCs residentes do linfonodocapturas antígenos solúveis transportados dentro dos canais das FRCs. c) FRCs produzem quimiocinas como CCL19 e CCL21 que atraem células T e DCs, as quais expressam o receptor CCR7. d) FRCs secretam citocinas como IL-7 a qual atua como sinal de sobrevivência para as células T naives ao se ligar com o receptor IL7R. Modificado de Turley et al, 2010. 


\subsubsection{Células fibroblásticas reticulares na indução de tolerância periférica}

FRCs exercem uma regulação positiva na homeostase e migração das células do sistema imune no LN através da síntese de CCL19, CCL21 e IL-7, embora recentes estudos descrevam as FRCs como responsáveis, mediante diversos mecanismos, também pela regulação negativa da resposta imune (Figura 2). Por um lado, as FRCs podem induzir tolerância nas células $\mathrm{T}$ via apresentação de antígenos próprios, e, por outro lado, podem diminuir as respostas das células $\mathrm{T}$ aos antígenos estranhos, pela expressão de fatores supressores, inibindo diretamente a expansão dos linfócitos ou indiretamente diminuindo a imunogenicidade das DCs (Fletcher et al, 2010; Turley et al, 2010; Khan et al, 2011; Lukacs-Kornek et al, 2011; Siegert et al, 2011).

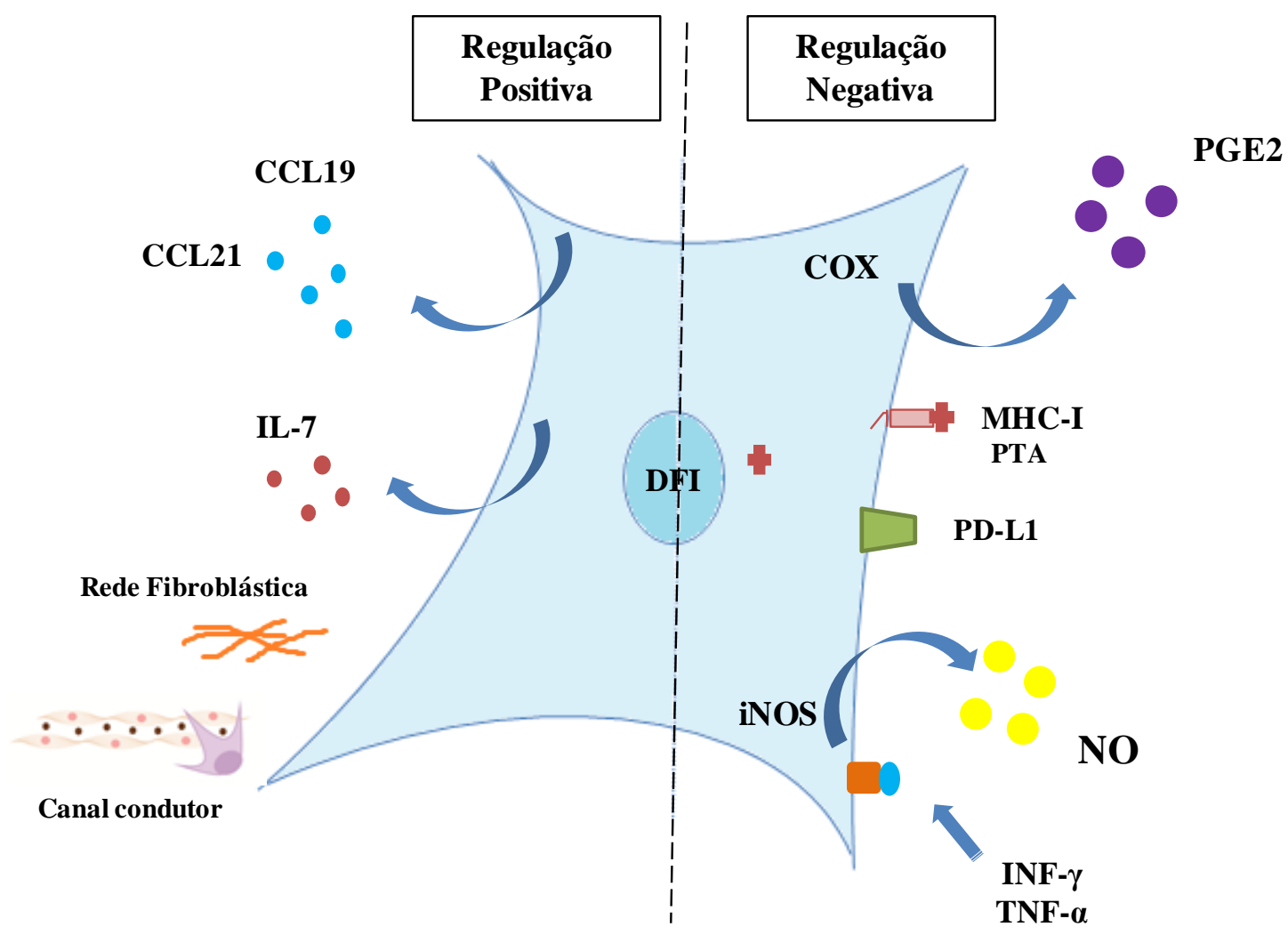

Figura 2. Diferentes mecanismos de ação das FRCs murinas na ativação da resposta imune e indução de tolerância periférica. 
Lee e colaboradores (2007) reportaram que antígenos próprios restritos ao intestino de murinos foram expressos ectopicamente por populações de células estromais em LNs não drenantes (do inglês, lymph-node estromal cells LNSCs). LNSCs apresentavam diretamente esses antígenos às células T CD8+ induzindo tolerância por mecanismos de deleção de células T autorreativas. Em condições não inflamatórias, as células não hematopoiéticas no LN expressam uma quantidade clinicamente relevante de antígenos restritos aos tecidos periféricos (do inglês, Peripheral Tissues Antigen PTA) (Lee et al, 2007; Nichols et al,2007; Magnusson et al, 2008; Gardner et al, 2008; Yip et al, 2009), contribuindo de maneira não redundante e altamente eficaz na indução de tolerância periférica (Lee et al, 2007; Nichols et al, 2007; Gardner et al, 2008; Magnusson et al, 2008).

Estudos reportam que as LNSCs induzem um estado de tolerância periférica, principalmente pela deleção de células autorreativas (Turley et al, 2010; Fletcher et al (b), 2011; Lukacs-Kornek et al, 2011; Siegert e Luther, 2012), sugerindo que as DCs não sejam as únicas células responsáveis por esse processo e que a expressão de PTAs não seja restrita ao estroma do timo. LNSCs podem apresentar PTAs como tirosina, a qual não é apresentada pelas DCs e sua expressão no timo é insuficiente para induzir tolerância (Nichols et al, 2007).

Adicionalmente, o papel na tolerância periférica é compartilhado por várias populações de células no LN, e cada população expressa um repertório diferente de PTAs (Cohen et al, 2010; Fletcher et al, 2010). Por exemplo, FRCs expressaram o antígeno tOVA em um modelo de camundongo iFABP-truncated ovalbumin (tOVA) (Fletcher et $a l, 2010)$, e foram as únicas células que expressaram o antígeno Mlana. Enquanto, LECs foram responsáveis pela expressão do antígeno da enzima tirosinase associada à melanócitos (do inglês, melanocyte-associated enzyme tyrosinase Tyr) no LN, com relevância clínica na tolerância periférica pela deleção de células T específicas para esse antígeno do repertório normal (Nichols et al, 2007; Cohen et al, 2010), pois elas escapam à seleção negativa no timo. Atualmente Mlana e Tyr constituem alvos para terapias imunológicas contra o melanoma (Trefzer et al, 2006).

A participação na indução de tolerância não tem sido demonstrada diretamente nas BECs e DNCs (Link et al, 2007; Fletcher et al, 2010), embora ambas populações de células expressem PTAs (Cohen et al, 2010; Fletcher et al, 2010). 
No timo, o Aire (do inglês, Autoimmune Regulator), mediante um mecanismo molecular complexo, é responsável por dirigir a expressão de uma variedade de PTAs expressos pelas células endoteliais nesse órgão (Anderson et al, 2002; Ramsey et al, 2002).

Embora nos LNs de camundongos fossem detectados níveis de transcritos para Aire expressos pelo estroma (Lee et al, 2007) estes foram principalmente expressos na população de DNCs (Cohen et al, 2010; Fletcher et al, 2010) observando-se somente em baixos níveis nas FRCs (Siergert et al, 2012), estudos recentes demonstraram que o Aire não regula a expressão da maioria de PTAs fisiologicamente significantes no LN (Cohen et al, 2010). Cohen e colaboradores (2010) observaram que LECs de camundongos nocaute (do inglês - knockout) para o gene Aire expressaram e apresentaram o antígeno tirosinase diretamente para as células T CD8+ naives, sugerindo a presença de outro fator regulador.

Recentemente foi descrita a presença de DEAF1 (do inglês, DEAF1, Transcription Factor), um fator de transcrição regulado pelo gene DF1 em FRCs e LECs, considerado o principal responsável da regulação da expressão de PTAs no LN (Yip et al, 2009). Em camundongos, DF1 existe em duas isoformas, o DF1 canônico e a forma variante (DF1-VAR1), proveniente de um splicing alternativo (do inglês Alternatively Spliced Variant in DF1, DF1-VAR1). O DF1 canônico tem capacidade de se translocar para o núcleo e regular a transcrição de PTAs, enquanto o DF1-VAR1 está expresso no citoplasma e pode inibir a transcrição dos PTAs ao sequestrar DF1 canônico no citoplasma. (Fletcher et al, 2011; Yip et al, 2009). Apesar da similaridade estrutural entre AIRE e DEAF1, ambos apresentam mecanismos diferentes no controle da expressão de PTAs (Turley et al, 2010).

Além do papel na indução de tolerância periférica como uma APC não convencional, evidências recentes sugerem a capacidade das FRCs de suprimir a proliferação de células $\mathrm{T} \mathrm{CD}^{+}$e $\mathrm{CD}^{+}$em inflamação aguda, independentemente da apresentação de antígenos (Khan et al, 2011; Lukacs-Kornek et al, 2011; Siegert et al, 2011).

As FRCs e as LECs podem inibir a proliferação das células T através de um mecanismo estritamente regulado, dependente da produção de oxido nítrico pela enzima 
oxido nítrico sintase induzível (do inglês, inducible nitric oxide synthase iNOS, NOS2), que é aumentada em resposta à ação sinérgica de citocinas como IFN- $\gamma$, TNF- $\alpha$ e pelo contato direto com as células $\mathrm{T}$ ativadas (Lukacs-Kornek et al, 2011). Essas citocinas são produzidas pelas células $\mathrm{T} \mathrm{CD} 8^{+}$dentro da 24 horas após ativação, e são detectadas pelas FRCs vizinhas (Siegert e Luther, 2012).

Óxido nítrico ou as espécies reativas derivadas do nitrogênio podem regular negativamente as células $\mathrm{T}$ pela nitrosilação de diversos resíduos de aminoácidos, levando à regulação negativa do complexo do receptor de células T (TCR) (Kasic et al, 2011; Siegert e Luther, 2012), ou pela depleção do substrato da enzima iNOS, a L-

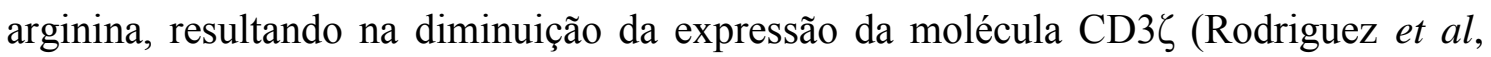
2002, Siegert e Luther, 2012). Finalmente, o efeito de supressão de células T pode ser devido ao bloqueio da fosforilação da molécula STAT5, interferindo na sinalização da via da IL-2 (Bingisser et al, 1998).

Adicionalmente, o estímulo pelo IFN- $\gamma$ induz as FRCs a produzirem outras moléculas reguladoras, como o ligante de morte celular programada-1 (do inglês, programmed cell death ligand 1 PD-L1) ou a enzima indolamine-2,3-dioxigenase (do inglês, indolamin-2,3-dioxygenase IDO (Khan et al, 2011; Lukacs-Kornek et al, 2011; Siegert et al, 2011). Tanto o PD-L1 como a IDO apresentam um papel importante no suporte da indução e manutenção de células T reguladoras, portanto, seria interessante entender a função das FRCs na geração, manutenção ou ativação dessas células $\mathrm{T}$ reguladoras (Francisco et al, 2010; Le Blanc e Mougiakakos, 2012).

A expansão das células $\mathrm{T}$, ativadas por DCs ou por mitógeno, pode ser fortemente atenuada in vitro quando colocadas na presença ou ausência de FRCs. Nesse contexto, tanto iNOS quanto as enzima cicloxigenase-1 e 2 (COX-1/2) foram as moléculas responsáveis pela inibição da proliferação e em menor medida a sua diferenciação em células efetoras.Além do mais, parte do efeito atenuante na expansão das células T pode ser devido a uma diminuição da imunogenicidade das DCs (Siegert et al, 2011; Siegert e Luther, 2012). Uma vez que DCs derivadas de medula óssea foram colocadas na presença de FRCs e posteriormente co-cultivadas com células T CD8+, apenas 50\% dos linfócitos mantiveram-se estimulados (Siegert e Luther, 2012). 
As enzimas COX-1/2, que participam da produção de $\mathrm{PGE}_{2}$, podem contribuir com o efeito inibitório da proliferação das células T (Siegert et al, 2011). A PGE2 também tem a capacidade de estimular DCs imaturas na periferia. Em contrapartida, parece induzir a supressão de DCs maduras nos órgãos linfoides secundários, diminuindo sua função como APCs (Gualde e Harizi, 2004; Siegert e Luther, 2012).

Em conjunto, a contribuição das FRCs mediante os mecanismos de regulação podem ser de grande relevância na proteção do tecido dos efeitos adversos de uma resposta imune exacerbada.

\subsubsection{Podoplanina e CLEC-2}

Podoplanina (PDPN, gp38) é uma proteína transmembrana de tipo mucina de 36-43 kD, altamente conservada entre as espécies, expressa em vários tecidos linfoides e não linfoides. Apresenta funções em diversos processos como na ontogenia de vários órgãos como coração, pulmão e sistema linfático; na motilidade celular, tumorogênese e metástase (Suzuki-Inoue et al, 2011; Astarita et al, 2012). Além disso, é requerida durante a separação dos vasos linfáticos e sanguíneos no desenvolvimento pela ativação de seu receptor o CLEC-2 expresso nas plaquetas (Bertozzi et al., 2010).

O CLEC-2 (codificado por Clec1b) é um receptor de lecitina tipo C, membro da família dos receptores de dectina-1, receptor para PDPN (Watson et al, 2010). Caracterizado pela sinalização através de um motivo de imunoreceptor baseado em tirosina (do inglês, immunoreceptor tyrosine-based activation motif ITAM) e da molécula adaptadora tirosina kinase (Syk) (Suzuki-Inoue et al, 2006). Está expresso em plaquetas e vários tipos de células mieloides incluindo neutrófilos, DCs do baço, DCs derivadas de medula óssea e macrófagos peritoniais (Kerrigan et al, 2009; Bertozzi et al, 2010).

A participação da gp38 no desenvolvimento de órgãos é variável. Nos rins, a gp38 é expressa em células epiteliais do glomérulo, conhecidas como podócitos, e parece ser essencial na função normal da filtração glomerular (Navarro-Núñez et al, 2013). No sistema nervoso central a gp38 é necessária para a formação correta do plexo coróide e é altamente expresso em tumores cerebrais (Astarita et al, 2012; NavarroNúñez et al, 2013). No coração, a gp38 é necessária para o desenvolvimento normal desse órgão, especialmente na transição epitélio-mesenquimal (do inglês, epithelial- 
mesenchymal transition, EMT). A gp38 também é necessária para o desenvolvimento pulmonar e maturação efetiva das células epiteliais alveolares do tipo I. No intestino não há ainda uma função específica determinada, apesar da gp38 estar expressa na lâmina própria. Em órgãos linfoides, é necessária para a formação e organização adequada, principalmente na arquitetura vascular linfática e indução da migração de DC nos LNs. Além disso, a gp38 está altamente expressa no estroma dos órgãos linfoides secundários e em tecidos linfoides ectópicos (Astarita et al, 2012).

Em câncer, a expressão de gp38 tem sido correlacionada com o aumento da linfangiogênese, mau prognóstico e presença de metástase. Esta molécula pode ser super-expressa em vários tipos tumorais e parece aumentar a atividade das GTPases Rho. O mecanismo exato de sua ação não está completamente elucidado (Astarita et al, 2012; Navarro-Núñez et al, 2013).

\subsubsection{Interação entre as células reticulares fibroblásticas e células dendríticas}

Níveis de mRNA e da proteína PDPN são expressos uniformemente por LECs e FRCs mas não em BECs, tanto em condições de repouso quanto inflamatórias. Expressão de mRNA para CLEC-2 foi verificada tanto em DCs isoladas de pele e LN, e sob condições inflamatórias essa expressão de superfície aumenta duas vezes, embora a molécula seja parcialmente internalizada (Acton et al, 2012).

PDPN, dependente de glicosilação, pode ligar com uma alta afinidade à quimiocina CCL21, produzida por FRCs e LECs (Kerjaschki et al, 2004). Esta interação pode ter efeitos no tráfego dos linfócitos e das DCs na zona de células T no linfonodo (Luther et al, 2000; Bajénoff et al, 2006; Turley et al, 2010).

As DCs migram através dos vasos linfáticos e entre a rede de FRCs na zona de células T. A interação entre podoplanina e CLEC-2 influencia o comportamento morfodinâmico e motilidade das DCs, uma vez que a deficiência de CLEC-2 nas DCs afetou sua entrada nos vasos linfáticos e seu tráfego até o LN, reduzindo a ativação das células T (Acton et al, 2012).

Em células mielóides, a sinalização de CLEC-2 pelo seu ligante parece aumentar a produção de IL-10, sugerindo sua participação na resolução da inflamação (Navarro-Núñez et al, 2013). Astarita e colaboradores (2014) indicaram que as DCs, 
expressando CLEC-2, constituíram uma rápida, embora reversível sinalização para as FRCs, CLEC-2 inibiu a função da PDPN o que resultou em um relaxamento das FRCs, que levou, por sua vez, ao aumento da rede reticular paracortical e expansão do LN. Quando ocorre a atenuação da sinalização CLEC-2, as FRCs retornam à sua capacidade contráctil levando à reverção do tamanho e arquitetura normal do LN.

As FRCs como BECs e LECs expressam MHC classe II sob condições inflamatórias induzidas por vírus, pelo tratamento com LPS ou IFN- $\gamma$, embora ainda seja pouco conhecido como essa expressão é regulada (Malhotra et al, 2012; Ng et al, 2012). Dubrot e colaboradores (2014) demostraram que a expressão do MHC classe II é dependente de IFN- $\gamma$ e do promotor pIV da proteína conhecida como transativador do MHC de classe II (do inglês, MHC class II transactivator CIITA), expresso nessas populações de células. Além disso, FRCs após co-cultivo com DCs maduras e imaturas, apresentaram expressão de MHC classe II, sugerindo que as DCs podem transferir complexos de MHC classe II para a superfície das FRCs.

\subsubsection{Remodelamento da rede de células fibroblásticas reticulares na expansão do linfonodo durante a resposta imune}

Durante a resposta imune ocorre o remodelamento do LN que inclui mudanças no tamanho, tráfego celular, assim como o crescimento e ativação dos vasos linfáticos e sanguíneos (Zhu e Fu, 2011). Contudo, os mecanismos exatos, as etapas, as moléculas e os sinais que levam à expansão do LN ainda não estão totalmente elucidados. Katakai e colaboradores (2004) ao avaliar alterações no tamanho de LNs poplíteos em camundongos imunizados ou não, observou que os LNs dos camundongos imunizados apresentaram maior tamanho que os LNs dos não imunizados. Além disso, observaram mudanças na distribuição dos linfócitos e localização das FRCs.

Yang e colaboradores (2014) descreveram que a zona de células T do LN de camundongos imunizados apresenta uma estrutura e organização conservada, embora sua região medular apresente maior número de células gp38 positivas após a imunização. Além disso, também ocorre aumento na celularidade total no $\mathrm{LN}$ e na proliferação dos linfócitos T antígeno-específicos, assim como a proliferação das FRCs 
tanto pela presença de um estímulo específico como inespecífico, embora, nesse último contexto, a proliferação seja menor. Ainda, foi observada maior proliferação das populações de LECs e BECs, o que sugere que a expansão das principais populações de células não hematopoéticas no LN contribui significativamente para a reorganização do LN ativado (Soderberg et al, 2005; Webster et al, 2006; Yang et al, 2013).

Deste modo, Yang e colaboradores (2014), sugerem duas fases no estado de ativação das FRCs durante uma resposta imune: uma precoce e outra tardia. A ativação mais precoce da FRCs parece ser controlada pelo recrutamento de linfócitos $\mathrm{T}$ naives induzido pelas DCs, pois os fibroblastos possuem a característica de apresentar sensibilidade mecânica, e, portanto, as FRCs podem detectar a pressão física do aumento do número de linfócitos T no paracórtex do LN (Link et al, 2007). Porém, o mesmo não é observado pela transferência de células dendríticas derivadas de medula óssea, na ausência de linfócitos. Já em uma fase de ativação tardia, caracterizada pelo aumento da expressão de moléculas como a gp38 e $\alpha$-SMA, estímulos derivados de linfócitos $\mathrm{T}$ ativados parecem resultar na diminuição do número e da proliferação das FRCs, devido à ausência das moléculas LT $\alpha \beta$ e LIGHT, ligantes do receptor LT $\beta R$ expressos em FRCs. Deficiências em outras vias de sinalização como TNF $\alpha$, LT $\alpha 3$, PDGF ou VEGF não parecem afetar a proliferação das FRCs (Yang et al, 2014).

Durante a fase tardia de inflamação no LN, a distribuição do VEGF-A na região paracortical e medular pode influenciar na remodelação dessas áreas (Tan et al, 2012). Chyou e colaboradores (2011) reportaram que as FRCs expressam mRNA para VEGF tanto em condições de repouso como após estímulo inflamatório, e sugerem que as DCs residentes CD11c+ podem estimular o aumento na produção de VEGF pelas FRCs após imunização. A via de sinalização do receptor LT $\beta$ R nas FRCs parece regular a produção de VEGF, visto que, em camundongos, o bloqueio desse receptor resultou na diminuição de $37 \%$ na produção de VEGF pelas FRCs no LN inflamado, diminuindo a proliferação das células endoteliais (Chyou et al, 2008).

Estudos sugerem que as DCs podem ser responsáveis pelo início do processo de remodelamento do LN na resposta imune. Yang e colaboradores (2013) descreveram que células endógenas do LN, DCs ou FRCs, podem responder a sinais de perigo via MyD88, levando eventualmente à proliferação das FRCs murinas. Recentemente observou-se que a interação da molécula de podoplanina (gp38), expressa nas FRCs, 
com seu receptor CLEC-2 presente nas DCs reduz a contratilidade das FRCs o que adicionalmente pode levar à expansão dessas células (Acton et al,2014; Astarita et al, 2014).

Em conjunto, esses dados sugerem um papel fundamental das FRCs durante a hiperplasia do LN ativado, essencial para a resposta imune adaptativa eficiente, tanto por contribuir para sua proliferação quanto para expansão de outros tipos celulares.

\subsection{Expressão gênica das células fibroblásticas reticulares e células duplo-negativas na homeostase e na inflamação}

As populações de FRCs, DNCs e células endoteliais como LECs e BECs, diferem no perfil de expressão gênica. As FRCs apresentam enriquecimento na expressão de genes que codificam moléculas envolvidas em interações entre a matriz extracelular e seus receptores, assim como moléculas de adesão e interação citocinasreceptores de citocinas. Já os genes expressos nas células endoteliais codificam para moléculas com função na transmigração de leucócitos, moléculas envolvidas na via de sinalização dos VEGFs e de adesão célula-célula (Malhotra et al, 2012).

Malhotra e colaboradores (2012) reportaram que no linfonodo de camundongos, em estado de repouso, tanto as FRCs, DNCs e células endoteliais expressam receptores para interferon tipo I e II, TGF- $\beta$ e TNF. FRCs e LECs, mas não BECs e DNCs, expressam transcritos de IL-7, importante na manutenção dos linfócitos naives no LN. As FRCs expressam um coestimulador de células $\mathrm{T}$ e fator de sobrevivência das células $\mathrm{B}$, o BAFF, além de produzir transcritos para moléculas de suporte às células mieloides como IL-34, Flt3L e CXCL14, assim como para quimiocinas CCL19, CCL21, CXCL13, CXCL12, CCL2 e CCL7.

FRCs e DNCs compartilharam expressão da integrina $\alpha_{11} \beta_{5}$, porém somente DNCs expressaram integrina de cadeia $\alpha_{2}, \alpha_{7}, \alpha_{8}, \alpha_{4}$. (Malhotra et al, 2012) Juntos esses dados sugerem que as FRCs estão envolvidas na regulação do recrutamento e localização de células hematopoiéticas nos órgãos linfoides secundários.

Os canais condutores formados pelas FRCs estão constituídos por um núcleo rico em colágeno, envolvido por uma zona microfibrilar que contem fibrilina e o 
antígeno reconhecido pelo anticorpo monoclonal ER-TR7. As FRCs como DNCs expressam transcritos para moléculas de colágeno tipo I, III, V, VI, IV, XIV e XVI (Sixt et al, 2005; Malhotra et al, 2012). Adicionalmente são capazes de regular a estrutura e organização dos condutos pela secreção de moléculas como pequenos proteoglicanos ricos em leucina (do inglês, small leucine-rich proteoglycans SLRPs), os quais regulam a fibrilogênese do colágeno, unem o colágeno tipo I à membrana basal e interagem com fatores de crescimento (Kalamajski e Oldberg, 2010).

FRCs e DNCs produzem metaloproteinases de matriz (do inglês, matrix metalloproteinases MMPs): MMP2, MMP3, MMP9, MMP14, importantes no remodelamento da matriz extracelular durante a expansão do LN na resposta imune (Malhotra et al, 2012).

As FRCs podem responder a estímulos inflamatórios incluindo IL-1, IFN- $\alpha \beta$, IFN- $\gamma$, and TNF- $\alpha$ (Katakai et al, 2004; Siegert et al, 2011), alterando a expressão de moléculas. Em camundongos, após estímulo com LPS, populações de FRCs, LECs e BECs mostraram uma alteração no perfil gênico. Nas FRCs houve um aumento na expressão de genes que codificam moléculas envolvidas na resposta de fase aguda e quimiocinas inflamatórias como CCL5 e CXCL9, bem como de transcritos gênicos que são induzíveis por interferons, via de sinalização do TLR4 ou moléculas adaptadoras como IRF7. Adicionalmente se observou aumento da expressão de genes que codificam para IL-7 e IL-33 (Malhotra et al, 2012), embora no estudo de Yang e colaboradores (2013), não tenham sido observadas mudanças na expressão de mRNA para IL-7, CCL19 e CCL21 após imunização.

Katakai e colaboradores (2004) verificaram que o nível de expressão das FRCs de CCL4, CCL5, CCL20 e CXCL10 em camundongos foi baixo em condições de repouso, aumentando em resposta ao estímulo com TNF- $\alpha$, além disso, nessas condições as FRCs demostraram aumento no seu potencial quimioatraente..

Adicionalmente, ao contrário das DNCs, as FRCs apresentaram maior expressão de genes que codificam diversos componentes da via de apresentação do MHC classe II após estímulo, que também induziu aumento dessa molécula na superfície das FRCs (Malhotra et al, 2012). 
Vega e colaboradores (2006) verificaram os níveis de expressão gênica de FRCs isoladas de LN humanos obtidos de pacientes com linfoma e hiperplasia benigna e os compararam com os de fibroblastos de pele em condições de repouso e após estímulo inflamatório com citocinas como TNF- $\alpha$, IL-6, IL-4 e IL-13. Observaram que, na ausência de estímulo, existe uma diferença no perfil de expressão gênica entre os fibroblastos obtidos das duas diferentes fontes, sugerindo uma especialização de acordo ao nicho celular. As FRCs isoladas de LN humanos mostraram expressão principalmente para genes que codificam quimiocinas, como CCL2 e citocinas como IL-1, IL-6, enquanto os fibroblastos de pele expressaram principalmente genes para metaloproteinases, fatores de crescimento de fibroblastos e fatores neurotrópicos. Os fibroblastos estimulados com TNF- $\alpha$ apresentaram expressão gênica semelhante, induzindo genes que codificam quimiocinas, citocinas e moléculas de adesão. Além disso, na ausência de estímulo, observaram alta expressão do gene para a quimiocina CCL2, que aumentou em 25 vezes sua expressão logo após o estímulo com TNF- $\alpha$.

Esses dados sugerem mais uma vez a ampla participação das FRCs na resposta aos estímulos inflamatórios tornando-se fundamental durante a resposta imune. Portanto, entender o funcionamento destas células pode nos ajudar a elucidar a modulação das respostas imunológicas.

\section{HIPÓTESE GERAL}

Nossa hipótese é que as FRCs e DNCs derivadas de linfonodos humanos, de forma similar às FRCs e DNCs murinas, possam influenciar a resposta imune.

\section{JUSTIFICATIVA}

O conhecimento da biologia, função e do real potencial das FRCs pode proporcionar conhecimento sobre a eficiência e as disfunções da resposta imune. Em modelos murinos, existem fortes evidências da participação destas células na tolerância periférica, entretanto estudos sobre as populações de FRC e DNCs de espécie humana são escassos. 


\section{OBJETIVOS}

\subsection{Geral}

Isolar e caracterizar fenotípica e funcionalmente as células estromais de linfonodos humanos.

\subsection{Específicos}

- Isolar e caracterizar as FRCs e DNCs de linfonodos humanos;

- Separar as subpopulações de acordo coma expressão de gp38 (FRCs e DNCs);

- Realizar ensaio de expressão gênica das subpopulações DNCs e FRCs derivadas de diferentes linfonodos em condições de repouso e após estímulo inflamatório;

- Identificar quimiocinas, citocinas e proteínas de superfície expressas nas DNCs e FRCs em condições de repouso e após estímulo inflamatório. 


\subsection{Característica amostral}

Linfonodos (LN) periféricos e mesentéricos foram obtidos de pacientes de diferentes diagnósticos e idades. Os participantes consentiram a doação dos LN por meio de assinatura do termo de consentimento livre e esclarecido. Este estudo foi aprovado pelos comitês de ética em pesquisa do Hospital Israelita Albert Einstein, da Irmandade da Santa Casa de Misericórdia de São Paulo e do Hospital das Clínicas da Faculdade de Medicina da USP-FMUSP sob CAAE número: 07768712.4.0000.0071. Os LNs foram submetidos a exame histopatológico para verificar se estavam saudáveis, sendo os comprometidos com metástase excluídos deste estudo. Informações sobre os LNs estão resumidas na Tabela 1.

Tabela 1.Característica amostral. Linfonodo (LN). Sem sucesso no estabelecimento da linhagem (-). Sucesso no estabelecimento da linhagem (+).

\begin{tabular}{|c|c|c|c|}
\hline Amostra & $\begin{array}{c}\text { Diagnóstico clínico do } \\
\text { paciente }\end{array}$ & $\begin{array}{c}\text { Resultado } \\
\text { anatomopatológico }\end{array}$ & Cultura celular \\
\hline LN 4 & Neoplasia laríngea & Negativo & + \\
\hline LN 7 & Doador de Fígado & Negativo & + \\
\hline LN 8 & Doador de Fígado & Negativo & + \\
\hline LN 11 & Diverticulite & Negativo & + \\
\hline LN 12 & Diverticulite & Negativo & + \\
\hline LN 14 & Neoplasia pancreática & Negativo & + \\
\hline LN 15 & Neoplasia mamária & Negativo & + \\
\hline LN 16 & Doador de Fígado & Negativo & + \\
\hline LN 18 & Neoplasia laríngea & Negativo & + \\
\hline LN 19 & Neoplasia laríngea & Negativo & + \\
\hline LN 23 & Doador de Fígado & Negativo & + \\
\hline LN 24 & Doador de Fígado & Negativo & + \\
\hline
\end{tabular}

\subsection{Análise anatomopatológica e imuno-histoquímica}

O exame anatomopatológico foi realizado pelo Laboratório de Patologia Clínica do Hospital Israelita Albert Einstein. Para o processamento anatomopatológico dos LNs doados para pesquisa, os órgãos foram fracionados em 2 metades, sendo que uma metade foi transferida para um tubo contendo formaldeído $10 \%$ e a outra metade foi utilizada para obtenção de células para cultivo. As metades preservadas em formaldeído foram desidratadas em soluções com concentração crescente de álcool etílico $(70 \%$, 
80\%, 90\%), passadas em álcool absoluto e em Xilol. Posteriormente realizou-se a impregnação e inclusão em parafina. As peças foram cortadas com espessura de 3 micrômetros e colocadas em lâminas de microscopia, mantidas em estufa a $37^{\circ} \mathrm{C}$ e submetidas às colorações com hematoxilina e eosina (coloração de HE), ou marcação individual com os anticorpos gp38, CD20, CD3 e CD68, segundo a técnica de imunohistoquímica.

\subsection{Obtenção de células estromais e linfócitos a partir de linfonodos humanos}

Os LNs foram coletados em cerca de $5 \mathrm{~mL}$ de meio de cultura (Mc1), contendo: Meio de Dulbecco Modificado (DMEM) (Gibco, Carlsbad, CA) suplementado com $10 \%$ de soro bovino fetal (FBS) (Gibco, Carlsbad, CA), 1\% de uma solução antibiótico-antimicótico composto por 10000 units/mL de penicilina, $10000 \mu \mathrm{g} / \mathrm{mL}$ de streptomicina e $25 \mu \mathrm{g} / \mathrm{mL}$ de Fungizone ${ }^{\circledR}$ (Gibco, Carlsbad, CA), e 1\% de Lglutamina 200mM (Gibco, Carlsbad, CA).

Após a coleta, os LNs foram colocados em placas de Petri e partidos ao meio com auxílio de bisturi e de uma pinça estéril, para a obtenção de linfócitos presentes no interior do LN. Metade deste órgão foi colocada em formaldeído $10 \%$ e encaminhada para Patologia Clínica para realização da avaliação histológica. O Mc1 contendo os linfócitos foi transferido para um tubo cônico Falcon de $15 \mathrm{~mL}$ e centrifugado por 5 minutos a $22^{\circ} \mathrm{C} / 500 \mathrm{~g}$. O sobrenadante foi descartado e o pellet submetido à contagem de células com coloração de azul de Tripan $0.4 \%$, para verificar-se a viabilidade e o cálculo do número de células obtidas. Estes linfócitos foram ressuspendidos em $1 \mathrm{~mL}$ de meio de congelamento (Mc2) /tubo, contendo: meio Mc1 com $10 \%$ de Dimetilsulfóxido (DMSO), e cada tubo com cerca de $2 \times 10^{6}$ céls $/ \mathrm{mL}$ foi mantido a $80^{\circ} \mathrm{C}$.

Após o extravasamento dos linfócitos, a metade do órgão foi fragmentada com auxílio de um bisturi e os fragmentos colocados em cerca de $10 \mathrm{~mL}$ de solução balanceada de Hank (do inglês Hank's balanced salt solution, HBSS) (Gibco, Carlsbad, CA) e submetidos à centrifugação por 10 minutos a $22^{\circ} \mathrm{C} / 500 \mathrm{~g}$, para lavagem dos tecidos. Após a lavagem, a amostra foi colocada em $10 \mathrm{~mL}$ de solução enzimática (MIX), composta por: $9 \mathrm{~mL}$ de HBSS, $1 \mathrm{~mL}$ de accutase (Innovative cell technologies, San Diego, CA), 0,6ng colagenase tipo II/mL, $1 \mu \mathrm{L}$ de turbo DNAse, $1 \mu \mathrm{L}$ de tampão da turbo DNAse (Invitrogen). O MIX contendo a amostra foi incubado em banho-maria a 
$37^{\circ} \mathrm{C}$ por 30 minutos sendo submetido à agitação mecânica em intervalos de 5 minutos, para auxiliar a digestão completa do tecido e liberação das células estromais.

Após esse período, os fragmentos de LNs foram colocados novamente em placas de Petri para desagregação final do tecido com auxílio de seringa e agulha. Em seguida, o MIX contendo a amostra foi centrifugado por 5 minutos a $22^{\circ} \mathrm{C} / 500 \mathrm{~g}$, o sobrenadante foi descartado, as células foram suspensas em Mc1 e cerca de $1 \times 10^{6} / \mathrm{mL}$ foram colocadas em frascos de cultura de $25 \mathrm{~cm}^{2}$, e incubadas em estufa de $5 \% \mathrm{CO}_{2}$ a $37^{\circ} \mathrm{C}$. Após 48 horas, foi realizada a primeira troca do Mc1, desprezando o Mc1 juntamente com as células que não aderiram à superfície plástica das garrafas de cultura e substituindo o meio descartado por novo Mc1 $5 \mathrm{~mL} /$ frasco. Posteriormente, realizou-se a troca de meio em dias alternados.

\subsection{Cultivo celular}

Todos os procedimentos foram realizados com FRCs e DNCs entre a $3^{\mathrm{a}}$ e a $10^{\mathrm{a}}$ passagem, preferencialmente na $4^{\mathrm{a}}$ passagem. Todas as células obtidas foram testadas para contaminação aeróbica, anaeróbica e para Mycoplasma sp. Quando as FRCs atingiram cerca de $90 \%$ de confluência, elas foram submetidas ao replaqueamento e/ou ao congelamento sempre na proporção de 1:3.

\subsection{Caracterização imunofenotípica de FRCs e DNCs por citometria de fluxo}

As células obtidas dos LNs humanos foram fenotipadas por citometria de fluxo, através das marcações: CD73, CD105, CD44, CD90, CD29, CD14, CD31, CD34, CD106, CD35, CD45, HLA-DR e gp38.

O conjunto de marcadores CD45, CD14, CD34 e HLA-DR auxilia na exclusão de células hematopoéticas. O marcador CD31 e CD106 permitem excluir as células endoteliais, como as linfáticas (LECs), as quais também expressam o gp38; e as sanguíneas (BECs). Já o marcador CD35 permite a exclusão das FDCs que, assim como as LECs, são gp $38^{+}$.

As análises imunofenotípicas das FRCs e DNCs foram realizadas através da citometria digital multiparâmetro FACS LSR II Fortessa (Becton Dickinson/BD, San Jose, CA) e os experimentos foram conduzidos com anticorpos de superfície disponíveis comercialmente. As técnicas de marcação foram realizadas de acordo com as indicações do fabricante. Brevemente, as células foram transferidas na concentração 
de $1 \times 10^{5}$ céls/tubo para a marcação com os anticorpos de interesse. Para a identificação e caracterização das FRCs e DNCs, foram utilizados dois tubos denominados 1 e 2 (Tabela 2). Os anticorpos marcados com seus respectivos fluorocromos que foram utilizados na identificação de FRCs e DNCs estão descritos na Tabela 3.

Como controle da especificidade das fluorescências foi realizado o controle de fluorescência menos um (do inglês Fluorescence Minus One, FMO).

Tabela 2. Painel utilizado na identificação e caracterização das FRCs e DNCs

\begin{tabular}{ccr}
\hline Canal de leitura & Tubo 1 & Tubo 2 \\
FITC & CD 106 & CD35 \\
PE & CD73 & CD34 \\
PE-CF594 & CD105 & CD105 \\
PercP-Cy55 & CD44 & CD44 \\
PE-Cy7 & CD90 & CD90 \\
APC & CD29 & gp38 \\
APC-H7 & HLA-DR & HLA-DR \\
Alexa 700 & CD14 14 \\
V450 & CD31 & CD31 \\
V500 & CD45 & CD45 \\
\hline
\end{tabular}

Tabela 3. Anticorpos utilizados na imunofenotipagem das FRCs e DNCs

\begin{tabular}{cccc}
\hline Anticorpo & Fluoróforo & Clone & Empresa comercial \\
CD 34 & PE & My10 & BD \\
CD 73 & PE & AD2 & BD \\
CD 35 & FITC & E11 & BD \\
HLA-DR & APC-Cy7 & G46-6 & BD \\
CD 90 & PE-Cy7 & SE10 & BD \\
CD 44 & PercP-Cy55 & G44-26 & BD \\
CD 29 & APC & MAR04 & BD \\
CD 45 & V500 & H130 & BD \\
CD 31 & V450 & WM59 & BD \\
CD 105 & Texas Red & 266 & BD \\
CD 14 & Alexa 700 & M5E2 & BD \\
GP38 & APC & $\bullet$ & R\&D \\
\multicolumn{4}{c}{ Anticorpo policlonal } \\
\hline
\end{tabular}




\subsection{Separação celular por cell sorting}

Após a análise imunofenotípica de FRCs e DNCs, essas populações celulares foram separadas fisicamente através da citometria digital multiparâmetro (FACS Aria Becton Dickinson/BD) com a técnica de cell sorting. Os experimentos foram conduzidos com o anticorpo gp38 de superfície previamente descrito e a técnica de marcação foi realizada de acordo com as indicações do fabricante. Os procedimentos foram realizados a fim de garantir a identificação, a separação e a esterilidade adequada. As células foram colocadas em tubo estéril, contendo cerca de $1 \times 10^{6}$ células/tubo, para a marcação com o anticorpo gp38. Em seguida as células foram separadas de acordo com a expressão do gp38, obtendo individualmente, a população de células gp $38^{+}$e gp38.

Após a separação celular, foi verificada a pureza das amostras. Posteriormente, estas células, ainda de forma estéril, foram colocadas em cultura para utilização em experimentos futuros.

\subsection{Procedimento de extração de RNA}

As células FRCs e DNCs previamente congeladas foram distribuídas em placas de 6 poços, com um total de $1,0 \times 10^{4}$ células por cada poço, em duplicata.

Ao atingirem uma confluência de $90 \%$ foram adicionados estímulos próinflamatórios com as citocinas: $50 \mathrm{ng} / \mathrm{mL}$ TNF- $\alpha$ (R\&D Systems, Minneapolis, USA) + 10ng/mL IL-1 $\beta$ (R\&D Systems, Minneapolis, USA) ou 100ng/mL IFN- $\gamma$ (R\&D Systems, Minneapolis, USA) durante 24 horas. Dois poços foram deixados sem estímulo inflamatório (controle).

Após 24 horas foi realizado o procedimento de extração de RNA total das culturas utilizando o kit de extração RNeasy Kit (QIAGEN, CA, USA), incluindo o passo de descontaminação de DNA genômico utilizando a enzima RNase-Free DNase Set (QIAGEN, CA, USA), conforme protocolo do fabricante. 
As amostras foram colocadas no gelo e a concentração, em ng/mL de RNA obtido, mensurada no aparelho NanoVue Plus Spectrophotometer (GE Healthcare, Alemanha)

\subsection{Avaliação da expressão gênica por microarranjos de DNA e validação dos resultados}

Comparamos os padrões de expressão gênica global (20 000 genes) entre os dois grupos de células quanto à resposta ao estímulo por TNF $\alpha+\mathrm{IL}-1 \beta$ e IFN- $\gamma$ : células gp $38^{+}$ e células gp38, obtidas por sorting e colocadas em cultivo. Cada um dos dois grupos possui células de um mesmo paciente submetidas aos dois tratamentos e células não tratadas, ou seja, seis diferentes condições de células por paciente. Os níveis de expressão dos genes codificadores de proteína foram avaliados utilizando DNA microarrays utilizando SurePrint G3 Human Gene Expression 8x60K v2 Microarray Kit (Agilent Technologies, USA). As amostras foram macardas com probes fluorescentes para cianina 3 (Cy3), os procedimentos de hibridização e lavagem seguiram estritamente os protocolos indicados pelo fabricante (One Color Quick Amp Labeling Kit, Agilent Technologies). Os arrays foram scaneados no equipamento SureScan Microarray Scanner (Agilent Technologies, USA) utilizando os paramentros padrões para Agilent microarrays. O processamento inicial dos dados foi realizado utilizando o software Agilent Feature Extraction (version 10.5) e o software GeneSpring (Agilent Technologies, USA) foi utilizado para a normalização e extração dos dados. Principal Component Analysis (PCA) foi utilizado para identificar os efeitos que mais influenciaram os dados e para a analise estatística subsequente utilizamos GeneSpring (Agilent Technologies, USA). A função biológica do padrão de expressão gênica foi explorada utilizando análise de enriquecimento de termos pelo Gene Ontology (GO) e o mapeamento das vias descritas no KEGG pathways utilizando DAVID Bioinformatics Resources 6.7 (http://david.abcc.ncifcrf.gov).

\subsection{Curva de Proliferação celular}

Para obter a curva de proliferação, as DNCs e FRCs foram colocadas em cultura e, quando confluentes foram plaqueadas $0,5 \times 10^{4}$ células por poço, das duas populações de células, em placas de 24 poços. Foi quantificado o número de células por citometría 
de fluxo nos dias $0,3,6,8$ e 10 de cultura. $O$ dia seguinte ao plaqueamento das células foi estabelecido como dia 0.

\subsection{Ensaio de expressão de PDPN}

As FRCs e DNCs, previamente congeladas, foram distribuídas em placas de 24 poços para cada amostra, uma concentração total de $0,5 \times 10^{4}$ células por poço. Ao atingirem uma confluência de $90 \%$ foram adicionados estímulos pró-inflamatórios com as citocinas: $50 \mathrm{ng} / \mathrm{mL}$ TNF- $\alpha$ (R\&D Systems, Minneapolis, USA) $+10 \mathrm{ng} / \mathrm{mL}$ IL-1 $\beta$ (R\&D Systems, Minneapolis, USA) ou 100ng IFN- $\gamma / \mathrm{mL}$ (R\&D Systems, Minneapolis, USA) durante 24 horas. Após esse período o meio com estímulos foi retirado e adicionou-se novo meio de cultura sem estímulo no qual as células foram mantidas por mais 24 horas. Em outro ensaio similar, as culturas foram mantidas em meio com os estímulos durante 48 horas.

Após esse período, o meio de cultura foi retirado dos poços que foram lavados com PBS. Posteriormente adicionou-se $500 \mu \mathrm{L}$ de tripsina a $37^{\circ} \mathrm{C}$ por 3 minutos. A ação da tripsina foi inativada adicionando-se $1 \mathrm{~mL}$ de meio de cultura contendo SFB. As células foram transferidas para tubos de citometria nos quais se realizou a marcação com $5 \mu \mathrm{L}$ do anticorpo gp38-APC, e a adquisição foi realizada no citômetro digital multiparâmetro FACS LSR II Fortessa (Becton Dickinson/BD, San Jose, CA).

\subsection{Ensaio de Curva de expressão de PDPN}

As FRCs, previamente congeladas, foram distribuídas em placas de 24 poços para cada amostra, em uma concentração total de $0,5 \times 10^{4}$ células por poço. Ao atingirem uma confluência de $90 \%$ foram adicionados estímulos pró-inflamatórios com as citocinas: $50 \mathrm{ng} / \mathrm{mL}$ TNF- $\alpha$ (R\&D Systems, Minneapolis, USA) + 10ng IL-1 $\beta / \mathrm{mL}$ (R\&D Systems, Minneapolis, USA) a cada poço. Deixamos seis poços como controle. O tratamento foi mantido até 48 horas, quando o meio com o estímulo foi retirado (dia $0)$.

Para avaliar a expressão de gp38, as células foram marcadas com o anticorpo gp38-APC e adquiridas no citometro FACS LSR II Fortessa (Becton Dickinson/BD, 
San Jose). As avaliações foram realizadas às 24 e 48 horas e nos dias 1, 2, 4 e 5 após a remoção do tratamento.

\subsection{Detecção da produção de quimiocinas e citocinas por ELISA}

As células FRCs e DNCs previamente congeladas foram distribuídas em placas de 6 poços, com um total de $1,0 \times 10^{4}$ células por poço, em duplicata.

Ao atingirem uma confluência de $90 \%$ foram adicionados estímulos próinflamatórios com as citocinas: 50ng/mL TNF- $\alpha$ (R\&D Systems, Minneapolis, USA) + 10ng/mL IL-1 $\beta$ (R\&D Systems, Minneapolis, USA) ou 100ng IFN- $\gamma$ (R\&D Systems, Minneapolis, USA) durante 24 horas. Dois poços foram deixados sem estímulo inflamatório (controle).

Obtivemos o sobrenadante das culturas em condições de repouso (controle) e após estímulo inflamatório. Pela técnica de ELISA, foram detectadas na cultura, produção, de quimiocinas: CCL2, CCL19, CCL20, CXCL12, CXCL8, e as citocinas: IL-6, IL-7 e IL-10.

Para detecção de CCL2, CCL20 e IL-7 foram usados os kits DuoSet ELISA Development (R\&D Systems, Minneapolis, USA). Para detectar CXCL12 o kit Quantikine® ELISA (R\&D Systems, Minneapolis, USA). Para a detecção de IL-6, CXCL8 e IL-10 foram usados kits de ELISA (Immuno tools, Friesoythe, Germany) segundo as instruções do fabricante.

\subsection{Ensaio de expressão de proteínas de superfície celular por citometría de fluxo}

As FRCs e as DNCs, previamente congeladas, foram distribuídas em placas de 24 poços para cada amostra, em uma concentração total de $0,5 \times 10^{4}$ células por poço. Ao atingirem uma confluência de 90\% foram adicionados estímulos pró-inflamatórios com as citocinas: 50ng/mL TNF- $\alpha$ (R\&D Systems, Minneapolis, USA) + 10ng/mL IL$1 \beta$ (R\&D Systems, Minneapolis, USA) ou $100 \mathrm{ng} / \mathrm{ml}$ IFN- $\gamma$ (R\&D Systems, 
Minneapolis, USA) durante 48 horas. Dois poços foram deixados sem estimulo inflamatório (controle).

Após 48 horas as células foram tripsinizadas e marcadas com os anticorpos para a determinação da expressão dos marcadores de superfície celular, no citometro FACS LSR II Fortessa (Becton Dickinson/BD, San Jose, CA). Determinou-se a expressão de CD40, CD83, CD274 (PD-L1), HLA-ABC e HLA-DR (Tabela 4).

Tabela 4. Anticorpos utilizados no ensaio de expressão de moléculas de superfície

\begin{tabular}{cccc}
\hline Anticorpo & Fluoróforo & Clone & Empresa Comercial \\
CD 274 & FITC & MIH1 & BD Pharmingen \\
CD 83 & PE & HB15a & Beckman Coulter \\
CD 40 & PE & $5 C 3$ & BD Pharmingen \\
HLA-ABC & FITC & G46-2.6 & BD Pharmingen \\
HLA-DR & PE & B8.12.2 & BD Pharmingen \\
\hline
\end{tabular}

\subsection{Análises de FACs}

Dados gerados a partir do FACs LSR II Fortessa e Aria (BD Biosciences, San Jose, CA), foram analisados pelos softwares FACSDIVA (BD Biosciences) e FlowJo (Treestar, Eugene, OR).

\subsection{Análise estatística}

As análises foram realizadas utilizando teste t-student para comparação entre 2 grupos e ANOVA para comparações entre mais de 2 grupos com correção de Bonferroni. Foi considerado significativo $\mathrm{p}<0,05$ em todos os experimentos. 


\section{RESULTADOS}

\subsection{A análise anatomopatológica e imuno-histoquímica dos linfonodos evidenciou morfologia íntegra dos órgãos isolados}

Através da análise anatomopatológica de cortes histológicos de LNs corados com HE pode-se avaliar o comprometimento patológico nos LNs e a integridade tecidual do órgão. Adicionalmente, através da técnica de imuno-histoquímica é possível verificar a distribuição das diversas células que o compõem (Meier-Ruge e Bruder, 2008).

Por isso, nós avaliamos a integridade celular do órgão pela coloração de HE, e a distribuição das células $\mathrm{T}$, células $\mathrm{B}$, macrófagos e células gp38+, por imunohistoquímica, segundo a marcação específica de CD3, CD20, CD68 e gp38, respectivamente.

Deste modo, selecionamos os LNs que representassem a heterogeneidade das amostras presentes no estudo. As análises histológicas das amostras mostram similaridade quanto à disposição celular entre os LN avaliados. Os linfócitos T foram observados no paracórtex (ou zona de células T) e, como esperado, os linfócitos B encontraram-se nos folículos linfoides (ou zona de células B). Macrófagos foram visualizados uniformemente espalhados por todo o LN. A fim de avaliar a presença de FRCs, realizamos a marcação de células gp $38^{+}$, e verificamos uma intensa e uniforme expressão de gp38 na zona de células T. Além desse local, gp $38^{+}$também foi expresso no SCS, folículos e nos vasos linfáticos, quando presentes (Figura 3).

Em conjunto, esses dados demonstram que os linfonodos avaliados apresentaram uma estrutura morfológica íntegra e com uma composição celular organizada, exceto na amostra proveniente de câncer na qual houve menor organização dos folículos linfoides comparado com as outras amostras. 
A

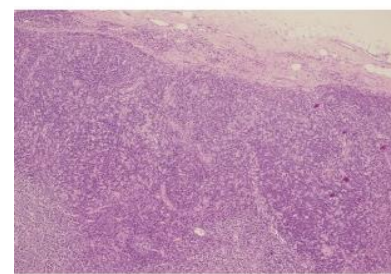

HE

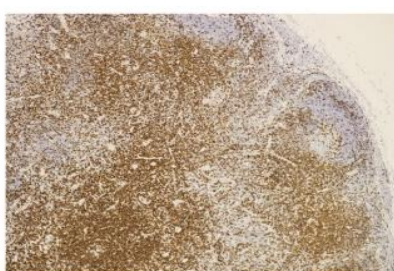

CD3

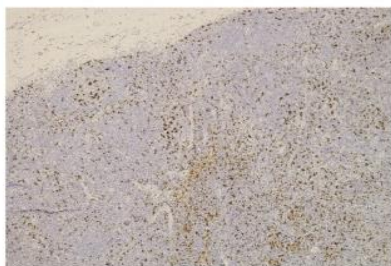

CD68

B

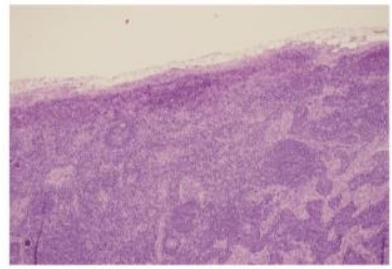

HE

CD3
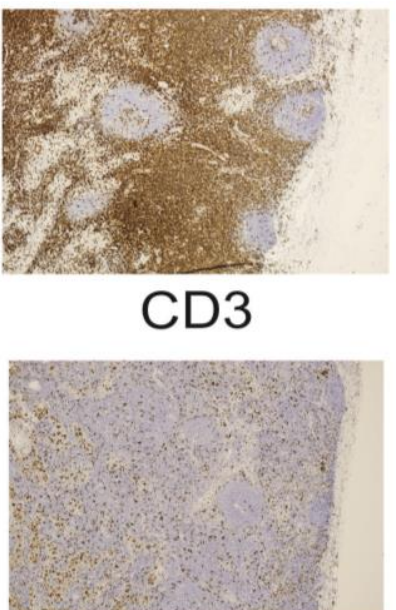

CD68

C

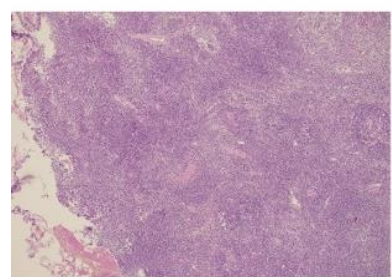

HE

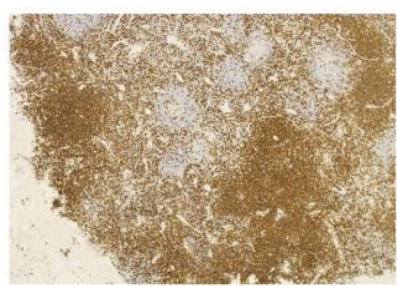

CD3

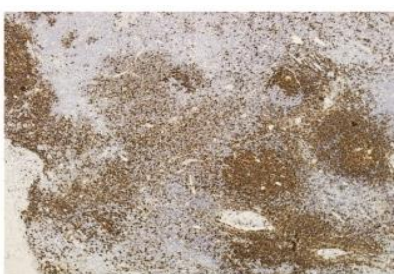

CD20

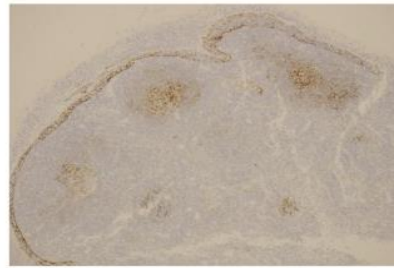

Gp38

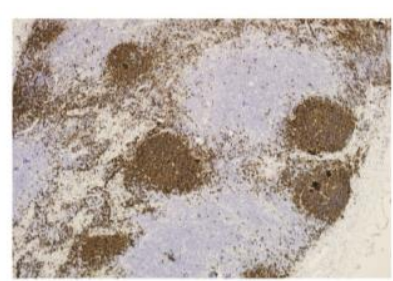

CD20

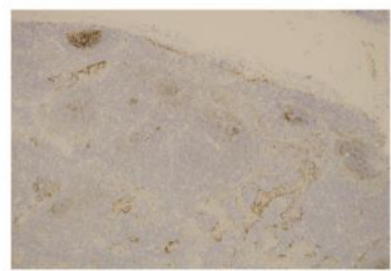

Gp38

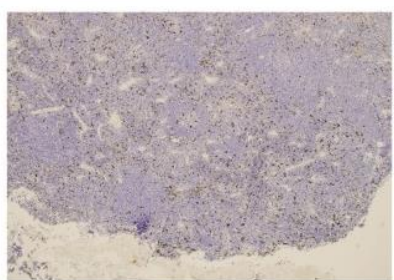

CD68

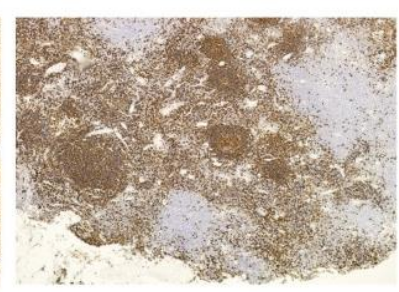

CD20

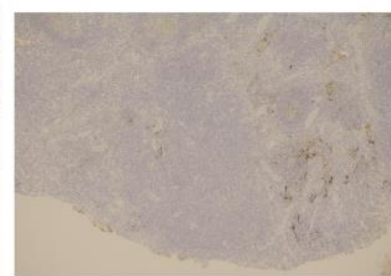

Gp38

Figura 3. Análise histopatológica de linfonodos (LNs) humanos. Foram coletados LNs de pacientes com câncer, diverticulite e doadores de fígado. A integridade e distribuição celular do órgão foram avaliadas pela coloração com hematoxilina e eosina (HE) e mediante a marcação com anticorpos para 
localização de linfócitos $\mathrm{T} \mathrm{CD}^{+}$, linfócitos $\mathrm{B} \mathrm{CD} 20^{+}$, macrófagos $\mathrm{CD}^{+} 8^{+}$e células gp38+. Imagem representativa dos cortes histológicos dos LNs derivados de (A) câncer de laringe, (B) doador de fígado e (C) diverticulite. Aumento de 10x.

\subsection{Caracterização imunofenotípica das células obtidas dos linfonodos humanos}

Em nosso estudo, as células isoladas dos LNs, não expressaram o marcador CD106, CD31 nem o CD35, excluindo a presença de células endoteliais e FDCs. Em relação à expressão de gp38, nossos dados mostraram a presença de duas populações de células, uma gp38+ e outra gp38- (Figura 4A).

Adicionalmente, observamos que mais de 90\% das células expressaram CD29, CD44, CD73, CD90 e CD105 e menos de 1\% de células expressaram CD14, CD34, CD45, CD106 e HLA-DR (Figura 4B).

Juntos, esses dados indicam que as células obtidas do processamento dos LNs humanos apresentam fenótipo de FRCs e DNCs. 
A

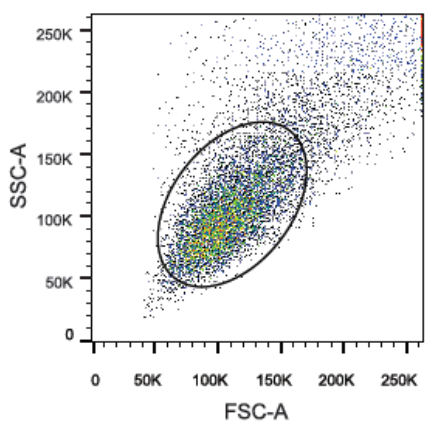

B
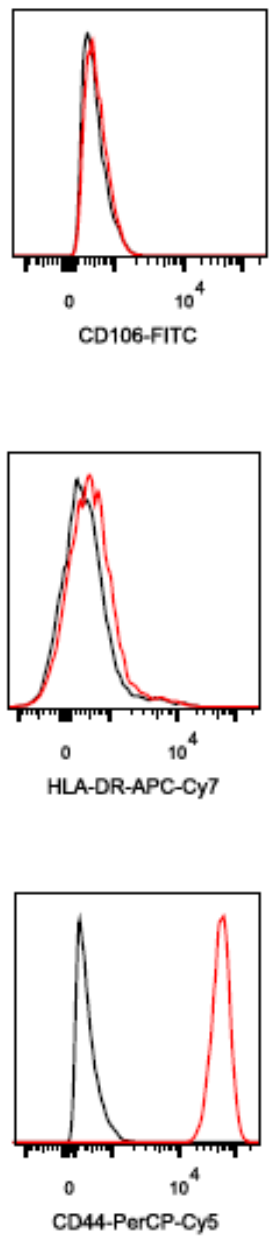

CD31-HorizonV450
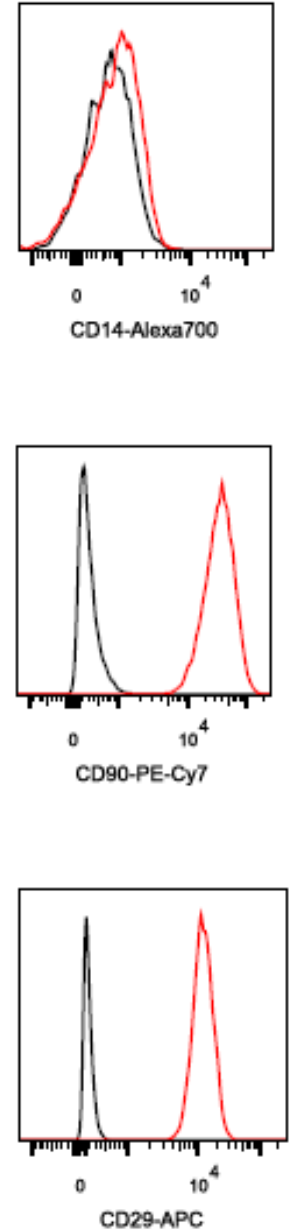
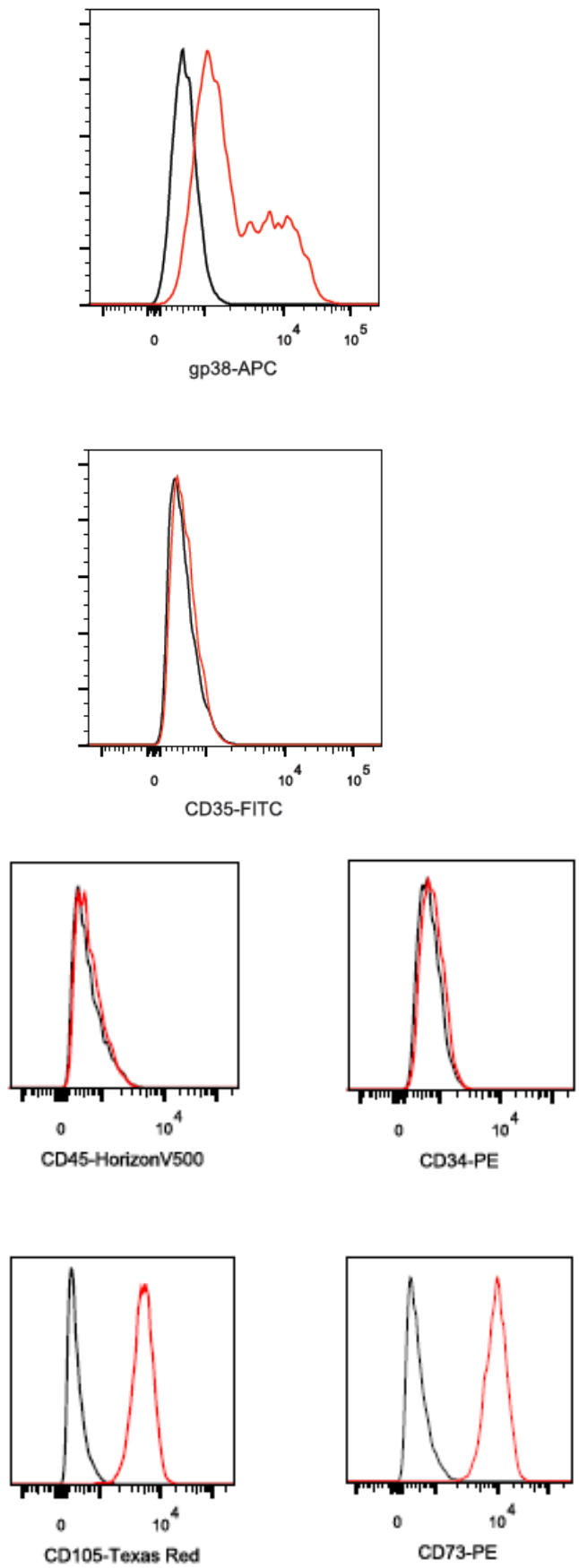

Figura 4. Dados representativos do perfil de expressão imunofenotípica das células obtidas do processamento de linfonodos humanos. Células estromais isoladas de LNs humanos foram colocadas em cultura; quando confluentes, por citometria de fluxo, avaliou-se o perfil imunofenotípico mediante a 
expressão ou não dos marcadores CD73, CD105, CD44, CD90, CD29, CD14, CD31, CD34, CD106, CD35, CD45, HLA-DR e gp38. (A) Estratégia de seleção populacional característica de células estromais (gate inicial), segundo o seu tamanho (FSC) versus granulosidade (SSC), além dos histogramas selecionados a partir do gate inicial, para os marcadores gp38, CD31 e CD35 (B) Histogramas selecionados a partir do gate inicial mostra a expressão ou não de CD106, CD14, CD45, CD34, HLA-DR, CD90, CD105, CD73, CD44 e CD29. Controle (linha preta) e as células marcadas (linha vermelha).

\subsection{A frequência de células estromais isoladas de linfonodos humanos varia segundo a expressão de gp38}

$\mathrm{Na}$ caracterização imunofenotípica das células estromais isoladas dos LNs humanos oriundos de doador de fígado e pacientes com câncer ou diverticulite, identificamos duas populações distintas de células, segundo o marcador gp38: as FRCs $\left(\mathrm{gp} 38^{+}, \mathrm{CD} 31^{-}\right)$e as DNCs $\left(\mathrm{gp} 38^{-}, \mathrm{CD}^{-} 1^{-}\right)$. Por citometria de fluxo, avaliamos a frequência das duas populações celulares.

Em conjunto, observamos a frequência média de 45,6 $\pm 13,8 \%$ de DNCs e $53,1 \pm 13,7 \%$ de FRCs, evidenciando uma grande variação nas porcentagens entre as duas populações, influenciadas pela condição do paciente do qual derivava o linfonodo (Figura 5A). Por isso, analisamos as porcentagens de FRCs e DNCs, por grupos de amostras: derivadas de câncer, diverticulite e doador de fígado.

Particularmente, nos linfonodos derivados de câncer, 59,2 $\pm 6,7 \%$ das células eram DNCs, significativamente distintas $(\mathrm{p}=0,008)$ das que exibiram o fenótipo de FRCs $(40,3 \pm 6,3 \%)$ (Figura 5B). Tal diferença na frequência também foi observada nas amostras derivadas de diverticulite, uma vez que 19,2 $\pm 6,4 \%$ das células dos LN drenantes eram DNCs, enquanto 80,2 $\pm 6,4 \%$ eram FRCs $(\mathrm{p}=0,005)$ (Figura 5D). Já nas amostras derivadas de doador de fígado, verificamos a presença de 45,3 $\pm 6,2 \%$ de DNCs e 52,3 $\pm 7,3 \%$ de FRCs (Figura 5C).

Nossos dados demonstram que os linfonodos avaliados apresentam frequências diferentes das populações celulares DNCs e FRCs, sugerindo que a doença pode interferir na composição celular estromal dos LNs. 


\section{Total de amostras}

A
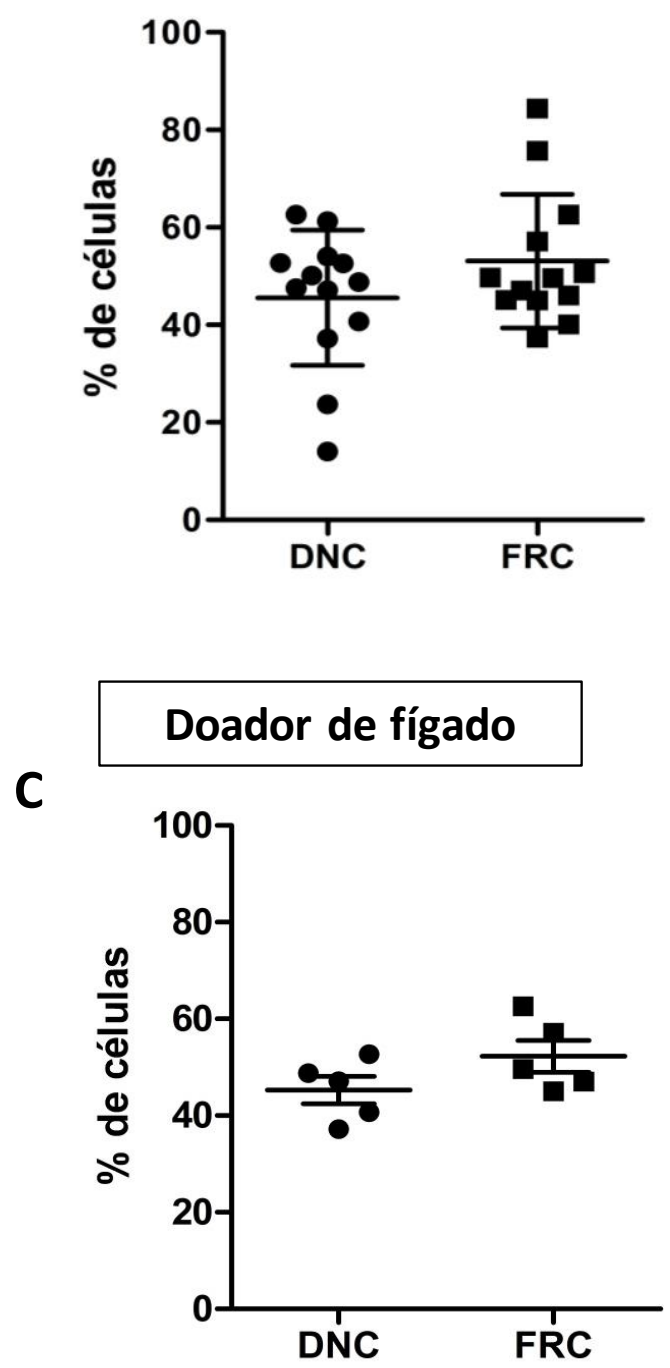

B
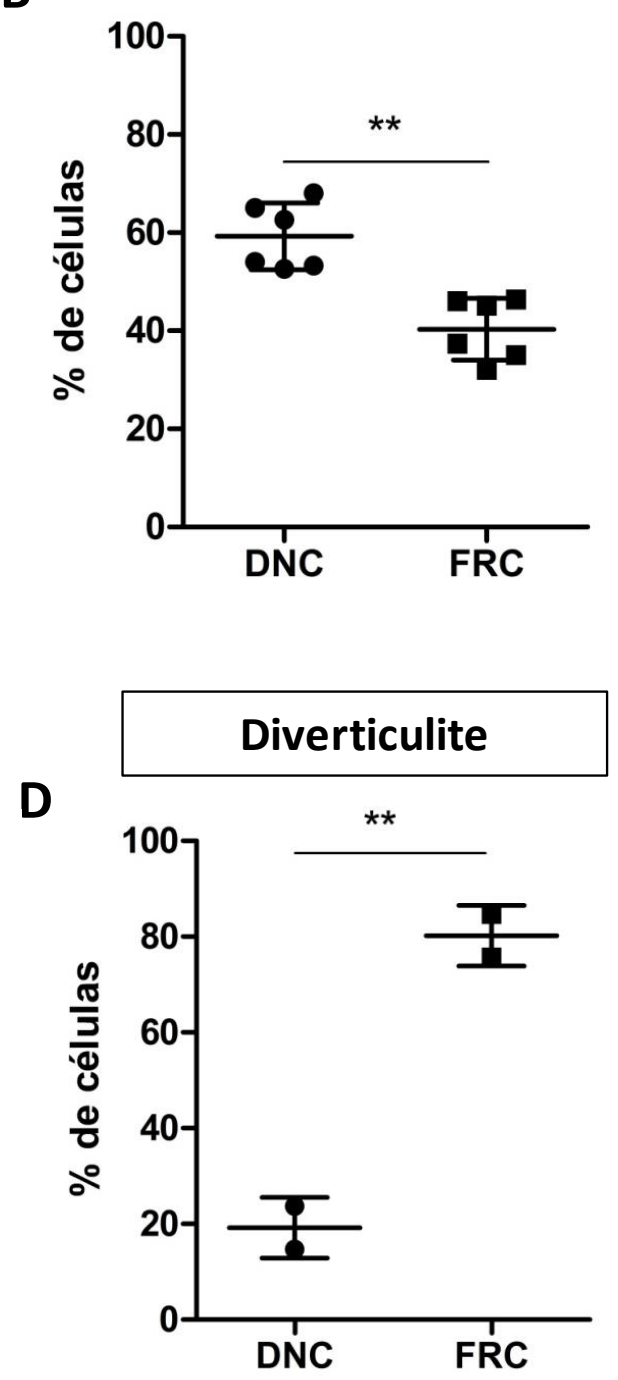

Figura 5. Diferença na frequência de FRCs e DNCs nos linfonodos humanos. DNCs e FRCs isoladas de LNs de pacientes com câncer, diverticulite e doador de fígado, foram cultivadas até atingir a confluência. Posteriormente, de acordo com a expressão de gp38 avaliou-se as porcentagens de DNCs e FRCs por citometria de fluxo. (A) Frequência de DNCs e FRCs no total de amostras (n=11), (B) nas amostras derivadas de pacientes com câncer $(n=6),(\mathbf{C})$ doadores de fígado $(n=3)$ e (D) pacientes com diverticulite. $(\mathrm{n}=2)$. $* * \mathrm{p}<0.01$ 


\subsection{Separação das FRCs e DNCs por cell sorting}

Como descrito acima, a caracterização imunofenotípica permitiu a identificação de duas populações de células: FRCs (gp38+ e CD31) e DNCs (gp38- e CD31) (Figura 4). Por citometria de fluxo, mediante a técnica do cell sorting, a qual permite a separação física e purificação celular, nós isolamos as duas populações de células, de acordo com a expressão ou não de gp38, colocamos em cultura separadamente para a realização dos ensaios posteriores.

$\mathrm{Na}$ análise, fizemos um gate para a exclusão dos doublets (duas células que se agregam ao passar pelo laser) (Figura 6A). A seguir, dentro da gate inicial, selecionamos nossa população de interesse, de acordo com as características de tamanho (FSC) e granularidade (SSC) (Figura 6B), e indicamos, segundo a expressão ou não do marcador gp38, as duas populações a serem separadas (Figura 6C).

Finalmente, depois da separação física das duas populações celulares, avaliamos a expressão do gp38 e verificamos a correta obtenção de FRCs (gp38 ${ }^{\text {hi }}$ ) e DNCs $\left(\mathrm{gp} 38^{\text {low }}\right.$ ) (Figura 6D). Deste modo, certificamos a aquisição de populações puras de FRCs e DNCs para ensaios posteriores. Após cultivo in vitro as células foram novamente fenotipadas quanto à expressão ou não de gp38 para comprovação da pureza. Quando esta não foi superior a 90\%, a separação das populações FRCs (gp38 hi) e DNCs $\left(\mathrm{gp} 38^{\text {low }}\right)$ por sorting, foi realizada novamente para garantir a pureza das populações celulares avaliadas. 

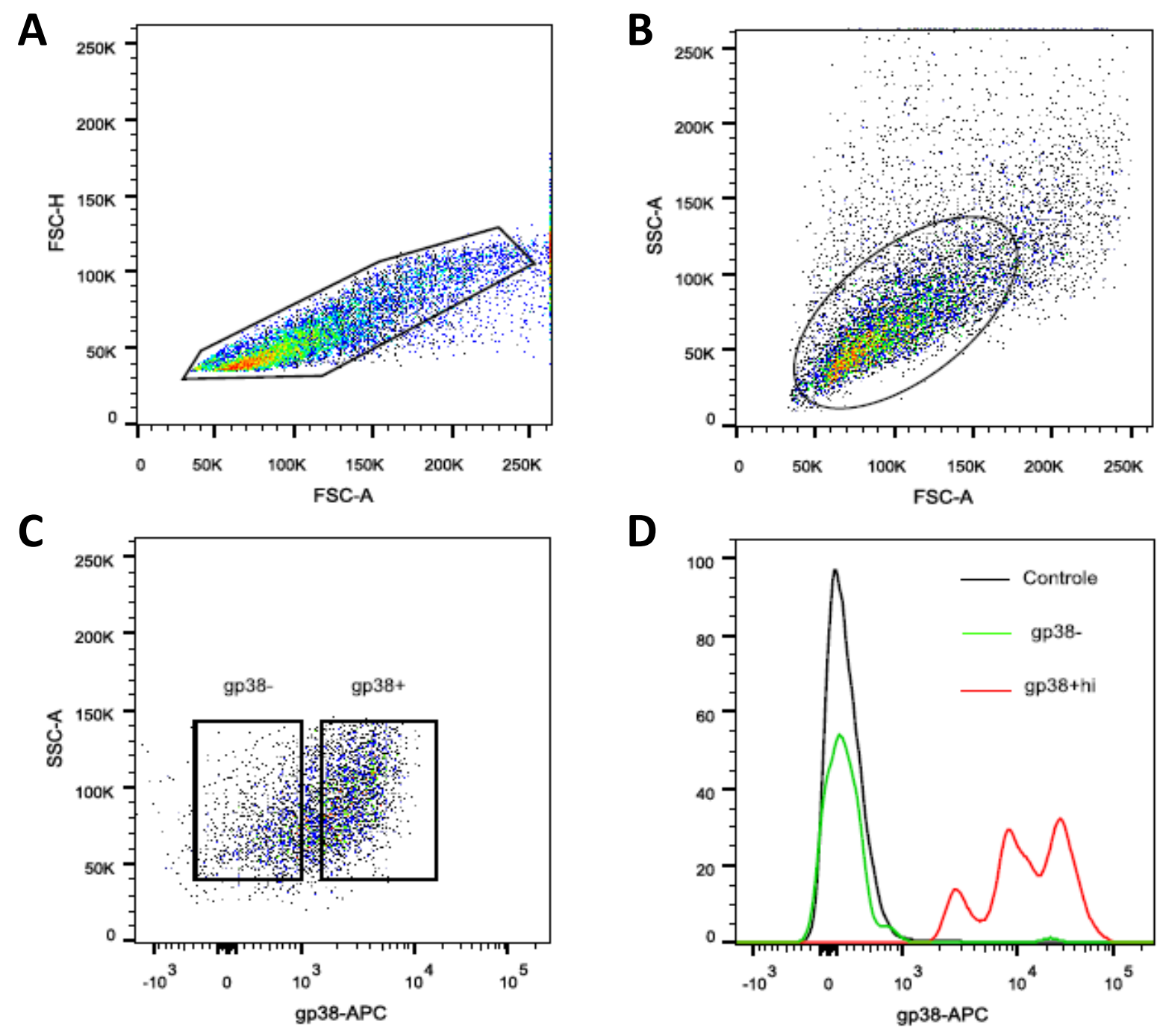

Figura 6. Separação física de FRCs e DNCs (Cell Sorting) proveniente de LNs humanos. Quando confluentes em cultura, às células estromais de LNs humanos, foram coletadas e marcadas com o anticorpo anti-gp38-APC e submetidas ao processo de sorting (A) Gate inicial para exclusão de doublets. (B) A partir do gate inicial, seleção da população de interesse segundo as características de tamanho (FSC) e granulosidade (SSC). (C) Seleção seguida de separação das células gp38+ e gp38- (D) Avaliação da pureza após a separação das células gp3 $8^{\text {low }}\left(\right.$ DNC) e células gp3 $38^{\text {hi }}$ (FRC), segundo a expressão do marcador. Mostra-se o controle não marcado (linha preta), células gp38 ${ }^{\text {low }}$ (linha verde) e células gp $38^{\text {hi }}$ (linha vermelha). 


\subsection{Expressão gênica de DNCs e FRCs}

Pela técnica de microarranjos de DNA, nós avaliamos o perfil de expressão gênica de DNCs e FRCs de quatro amostras: amostra de câncer de laringe (LND04), câncer de mama (LND15), diverticulite (LND12) e doador de fígado (LND16); em condições homeostáticas e após estímulo inflamatório com IFN- $\gamma$ ou TNF- $\alpha+$ IL- $\beta$ por 24 horas.

Agrupamos os genes que foram superexpressos nas quatro amostras de FRCs e os genes comumente expressos nas DNCs. Em seguida, para cada amostra individualmente, comparamos os genes superexpressos nas DNCs tratadas com estímulos inflamatórios versus não tratadas (Controle) e FRCs tratadas versus não tratadas. A mesma análise foi realizada para os dois tratamentos. Os dados da expressão gênica foram comparados pelo aumento de expressão em número de vezes.

Após tratamento com IFN- $\gamma$, em todas as amostras observamos superexpressão de genes que codificam quimiocinas como CCL2, CCL8, CXCL12, CXCL10, CXCL11, tanto nas FRCs quanto nas DNCs. Do mesmo modo, verficamos superexpressão gênica das citocinas IL-6, nas FRCs; IL-15, nas DNCs; IL-32 e IL-33, nas duas populações, entre outras. Similarmente, transcritos para receptores de citocinas como IL15RA, IFNAR2, nas duas populações. (Tabela 5)

Apresentaram maior expressão também, genes que codificam as moléculas do MHC-I e MHC-II, nas duas populações. Genes que transcrevem proteínas envolvidas na coestimulação CD40 e CD83 foram superexpressos somente nas FRCs; e genes de regulação da resposta imune como IDO-1, PD-L1, nas duas populações.

De modo complementar, observou-se maior expressão do gene gp38 em todas as amostras, variando na intensidade entre DNCs e FRCs, segundo o tipo de amostra (Tabela 5). 
Tabela 5. Genes superexpressos em FRCs e DNCs tratadas com IFN- $\gamma$ comparados aos controles (FRCs e DNCs não tratadas) (Fold change). A tabela mostra os genes com expressão aumentada (número de vezes) nas DNCs e FRCs em resposta ao IFN- $\gamma$ comparadas ao controle. Foram considerados somente genes envolvidos na resposta imunológica, que aumentaram 2 vezes ou mais e que foram superexpressos nas quatro amostras avaliadas.

\begin{tabular}{|c|c|c|c|c|c|}
\hline \multicolumn{6}{|c|}{ Genes de quimiocinas } \\
\hline GENE & DNC & FRC & GENE & DNC & FRC \\
\hline CCL2 & 14,25 & 5,64 & CXCL8 & --- & 31,34 \\
\hline CCL5 & 17,66 & --- & CXCL9 & --- & 1295,38 \\
\hline CCL7 & 33,99 & 35,61 & CX3CL1 & ---- & 8,45 \\
\hline CCL8 & 127,85 & 371,01 & CCRL2 & --- & 3,03 \\
\hline CCL13 & 81,09 & 172,08 & CXCL10 & 286,62 & 636,32 \\
\hline CXCL2 & 60,09 & 3,87 & CXCL11 & 205,01 & 355,31 \\
\hline CXCL3 & 8,35 & 8,35 & & & \\
\hline \multicolumn{6}{|c|}{ Gene da proteína gp38 } \\
\hline GENE & DNC & FRC & GENE & DNC & FRC \\
\hline PDPN & 7,56 & 4,93 & & & \\
\hline \multicolumn{6}{|c|}{ Interleucinas, proteína ligante de interleucina e receptores de citocinas } \\
\hline GENE & DNC & FRC & GENE & DNC & FRC \\
\hline IL4I1 & 8,66 & --- & IL15 & --- & 4,93 \\
\hline IL6 & 4,60 & --.-- & IL15RA & 22,85 & 15,17 \\
\hline IL32 & 15,90 & 11,82 & IFNAR2 & 3,16 & 4,90 \\
\hline IL33 & 6,61 & 5,27 & IL18BP & --- & 184,18 \\
\hline IL3RA & 7,59 & --- & IL31RA & --- & 4,39 \\
\hline \multicolumn{6}{|c|}{ Genes de HLA- I e HLA-II } \\
\hline GENE & DNC & FRC & GENE & DNC & FRC \\
\hline HLA-B & 6,51 & 9,22 & HLA-DMA & --- & 66,02 \\
\hline HLA-C & --- & 5,58 & HLA-DMB & $-\cdots$ & 534,90 \\
\hline HLA-E & --- & 6,15 & HLA-DOA & --.- & 218,85 \\
\hline HLA-F & 4,78 & 5,09 & HLA-DOB & $-\cdots$ & 37,19 \\
\hline HLA-G & --- & 5,23 & HLA-DPA1 & -.- & 27,10 \\
\hline HLA-J & 5,64 & 6,31 & HLA-DPB1 & $-\cdots$ & 6,90 \\
\hline HLA-DRA & 245,63 & 240,33 & HLA-DQA1 & $-\cdots$ & 19,69 \\
\hline HLA-DRB1 & --- & 79,89 & HLA-DQA2 & --. & 6,56 \\
\hline HLA-DRB4 & $-\cdots$ & 73,79 & HLA-DQB1 & $-\cdots$ & 54,34 \\
\hline HLA-DRB5 & $-\cdots$ & 380,51 & & & \\
\hline \multicolumn{6}{|c|}{ Genes de regulação da resposta imune } \\
\hline GENE & DNC & FRC & GENE & DNC & FRC \\
\hline IDO-1 & 2958,32 & 5128,07 & PD-L1 & 28,30 & 36,01 \\
\hline \multicolumn{6}{|c|}{ Genes de moléculas coestimuladoras } \\
\hline GENE & DNC & FRC & GENE & DNC & FRC \\
\hline CD40 & --- & 16,09 & CD83 & --- & 3,71 \\
\hline
\end{tabular}


Referente ao tratamento com TNF- $\alpha+$ IL- $1 \beta$, também foram superexpressos nas DNCs e FRCs genes de proteínas da via de sinalização do TNF, transcritos para quimiocinas como: CCL2, CCL3, CCL5, CCL7, CXCL8, CXCL10, etc. Individualmente as DNCs superexpressaram transcritos para CCL8 e FRCs para CCL20, CXCL5, CXCL6. Por outro lado, similar à resposta ao IFN- $\gamma$ ocorreu aumento de expressão de MHC-I, além de moléculas envolvidas no processamento antigênico desta via: TAP1 e TAP2; nas duas populações celulares. De forma interessante, foi observada superexpressão de transcritos de CTSS que codifica para a molécula catepsina S, entretanto não ocorreu expressão de classe II (Tabela 6). 


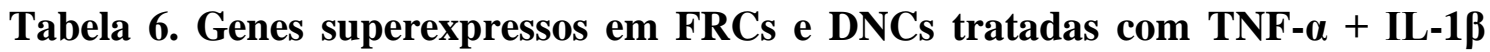
comparados aos controles (FRCs e DNCs não tratadas) (Fold change). A tabela mostra os genes com expressão aumentada (vezes) nas DNCs e FRCs em resposta ao TNF- $\alpha+$ IL-1 $\beta$ comparados aos controles. Foram considerados somente genes envolvidos na resposta imunológica, que aumentaram 2 vezes ou mais e que foram superexpressos nas quatro amostras avaliadas.

\begin{tabular}{|c|c|c|c|c|c|}
\hline \multicolumn{6}{|c|}{ Genes da via de sinalização do TNF- $\alpha+$ IL-1 } \\
\hline GENE & DNC & FRC & GENE & DNC & FRC \\
\hline IFNAR2 & --- & 7,41 & TRAF2 & --- & 3,12 \\
\hline IL1RN & --- & 292,72 & TRAF3IP2 & $\begin{array}{c}-- \\
\end{array}$ & 10,35 \\
\hline TNFRSF1B & --- & 6,93 & IRAK2 & --- & 73,40 \\
\hline TNFRSF8 & --- & 5,47 & IRAK3 & --- & 32,59 \\
\hline TNFRSF9 & --- & 9,59 & NF-кB1 & --- & 11,18 \\
\hline TNFAIP2 & 6,44 & 6,20 & NF-кB2 & --- & 4,19 \\
\hline TNFAIP3 & --- & 28,67 & NF-кBIA & --- & 10,67 \\
\hline TNFAIP6 & 19,76 & 31,81 & NF-кBID & --- & 4,99 \\
\hline TNFAIP8 & --- & 4,14 & NF-кBIZ & 5,78 & 6,79 \\
\hline \multicolumn{6}{|c|}{ Genes de HLA- I e HLA-II } \\
\hline GENE & DNC & FRC & GENE & DNC & FRC \\
\hline HLA-B & 2,65 & 3,14 & TAP2 & 4,56 & 59,84 \\
\hline HLA-C & 11,97 & 2,65 & CTSS & 13,95 & 23,27 \\
\hline TAP1 & 5,44 & 8,19 & HLA-F & --- & 2,29 \\
\hline \multicolumn{6}{|c|}{ Genes de quimiocinas } \\
\hline GENE & DNC & FRC & GENE & DNC & FRC \\
\hline CCL2 & 22,47 & 27,20 & CXCL8 & 3488,01 & 4894,07 \\
\hline CCL3 & 88,51 & 191,68 & CXCL10 & 147,77 & 13,51 \\
\hline CCL5 & 126,54 & 84,70 & CCL3L3 & --- & 8,46 \\
\hline CCL7 & 52,04 & 51,94 & CCL11 & --- & 7,63 \\
\hline CCL8 & 60,55 & --- & CCL13 & --- & 9,86 \\
\hline CXCL1 & 2207,39 & 444,12 & CXCL5 & --- & 51,53 \\
\hline CXCL2 & 471,96 & 304,46 & CXCL6 & --- & 1134,17 \\
\hline CCL20 & --- & 409,46 & & & \\
\hline
\end{tabular}


Por último, quando não tratadas, observamos que DNCs e FRCs superexpressam diferentes grupos de genes envolvidos na proliferação e controle da proliferação celular no total de amostras $(\mathrm{p}<0,05)$. As DNCs expressaram transcritos como GINS1, BLM, ID4, CDCA7, TACC2, entre outros; já as FRCs, expressaram genes como CALCA, TDGF1, VASH2, FLT4, FGFR3, IL6, IL-21, PAX6 e o gene da proteína gp38 (PDPN) (Tabela7).

Tabela 7. Expressão diferencial de genes relacionados à proliferação e controle da proliferação celular

\begin{tabular}{|l|l|}
\hline \multicolumn{2}{|l|}{ DNC } \\
\hline $\mathrm{p}<0,05$ & $\begin{array}{l}\text { HAUS, FANCA, BRCA1, ADRB2, MECON, KIF15, UHRF1, } \\
\text { CCNA2, BUB1, TRIM24, HELLS, ID1, GINS1, BLM, ID4, CDCA7, } \\
\text { TACC2, TTK, RACGAP1, ASPM, SSTR1, LRP2, TCF19 }\end{array}$ \\
\hline FRC & $\begin{array}{l}\text { CYP1A1, TP63, GATA4, EGLN3, CALCA, TDGF1, VASH2, FLT4, } \\
\text { FGFR3, IL6, PAX6, PDPN, AZGP1P1, SCG2, ENPP7, TNFRSF13B, } \\
\text { IL21 }\end{array}$ \\
\hline
\end{tabular}




\subsection{Curva de proliferação de DNCs e FRCs}

A expressão gênica evidenciou expressão de diferentes genes relacionados com proliferação celular, tanto na população de FRCs quanto de DNCs. Nós acompanhamos, em condições homeostáticas, a proliferação de ambas as populações nas amostras de linfonodos oriundos de pacientes com câncer e de doador de fígado.

Nós observamos que, em todas as amostras, existe maior velocidade na proliferação das FRCs comparada as DNCs (Figura 7). Tais dados demonstram que as FRCs possuem maior potencial proliferativo em relação às DNCs na ausência de estímulos exógenos.

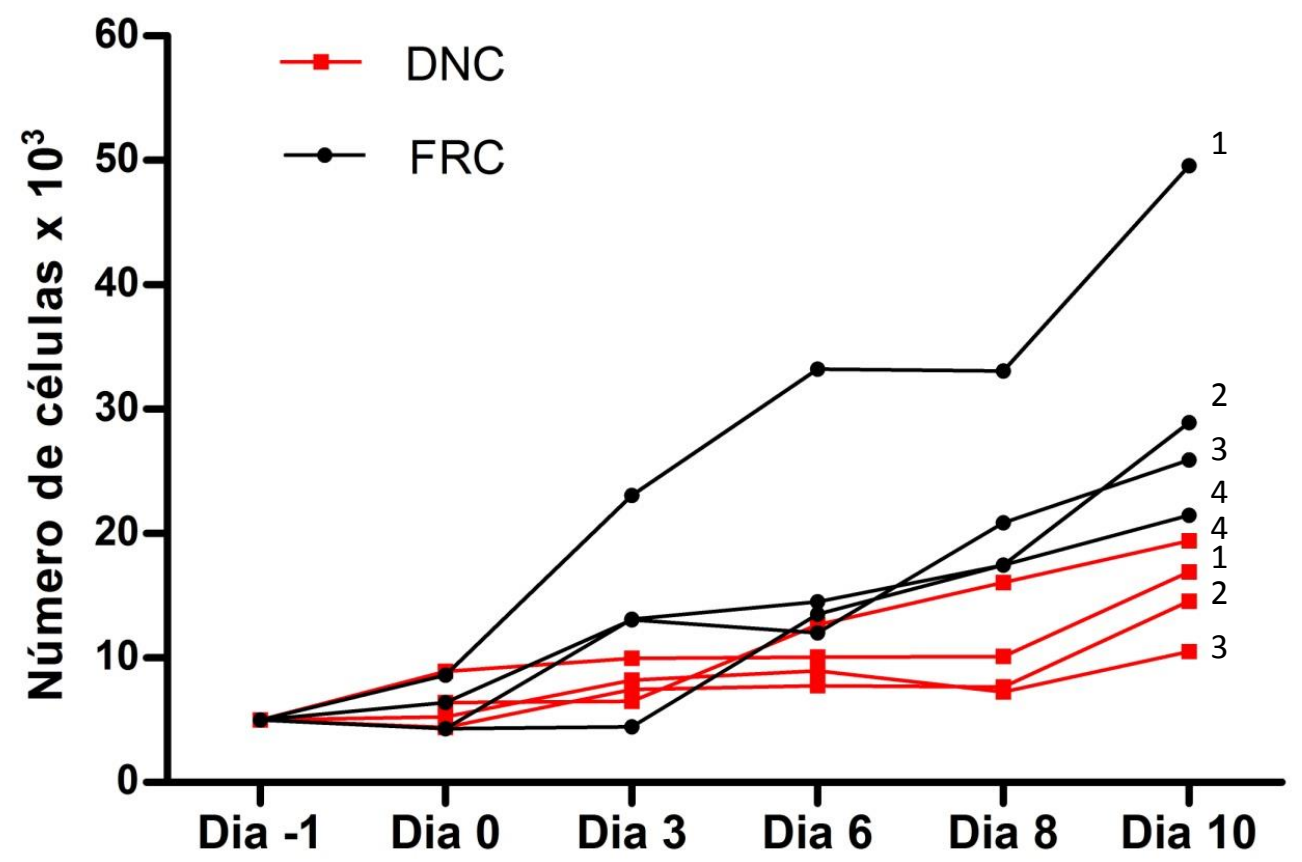

Figura 7. Curva de proliferação de DNCs e FRCs. Populações de células gp $38^{+}$(FRCs) e gp38-(DNCs) foram cultivadas em meio DMEM suplementado com $10 \%$ de soro fetal bovino e $1 \%$ de antibióticoantimicótico. A quantidade de células foi determinada por citometría de fluxo nos dias 0, 3, 6, 8, 10. A linha preta representa as FRCs enquanto a vermelha, as DNCs. Dados representativos de quatro experimentos realizados separadamente. Día -1:dia do plaqueamento.1:LND16; 2:LND04; 3:LND19; 4:LND18. 


\subsection{FRCs e DNCs aumentam a expressão de gp38 após tratamento com citocinas inflamatórias}

$\mathrm{Na}$ análise de expressão gênica observamos que quando tratadas com IFN- $\gamma$ ou TNF- $\alpha+$ IL-1 $\beta$ ocorre aumento da expressão do gene que codifica gp38 tanto nas FRCs quanto nas DNCs. Para verificar se o estímulo inflamatório induz alteração na expressão desta molécula na superfície celular, as duas populações de células DNCs e FRCs, foram colocadas em cultura e submetidas separadamente aos dois tratamentos com citocinas inflamatórias IFN- $\gamma$ ou TNF- $\alpha+$ IL-1 $\beta$ por 24 e 48 horas. Posteriormente, por citometria de fluxo, se avaliou a diferença no MIF para o marcador gp38.

Observamos aumento na expressão de gp38 tanto nas DNCs quanto nas FRCs em todas as amostras após tratamento com IFN- $\gamma$ e TNF- $\alpha+$ IL-1 $\beta$, em relação às células não tratadas (Controle). Entretanto, a intensidade de resposta aos estímulos variou entre as amostras (Figura 8).

Individualmente, após o tratamento com IFN- $\gamma$, nas células derivadas de câncer, às 24 horas o MFI aumentou de 2,1 x $10^{3}$ para 4,9 x $10^{3}$, nas DNCs e de $2,9 \times 10^{3}$ para $7,9 \times 10^{3}$ nas FRCs; às 48 horas para $3,6 \times 10^{3}$ nas DNCs e 9,7 x $10^{3}$ nas FRCs. O tratamento com TNF- $\alpha+$ IL- $1 \beta$, às 24 horas, resultou em aumento na expressão de gp 38 de $2,1 \times 10^{3}$ para $3,7 \times 10^{3}$ nas DNCs e de $2,9 \times 10^{3}$ para $9,5 \times 10^{3}$ nas FRCs, alcançando $7,1 \times 10^{3}$ nas DNCs e 10,1 x $10^{3}$ nas FRCs, às 48 horas (Figura 8 A).

Entretanto, na amostra derivada de diverticulite tratada com IFN- $\gamma$, o MFI foi de 2,6 $\times 10^{3}$ para 4,9 x $10^{3}$ nas DNCs e de $19,2 \times 10^{3}$ para 42,5 × $10^{3}$ nas FRCs, às 24 horas

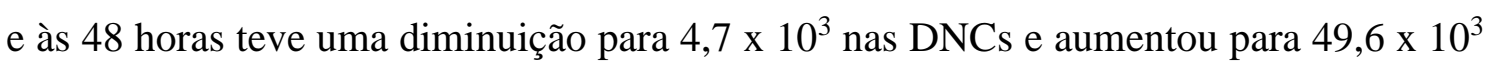
nas FRCs. O tratamento com TNF- $\alpha+$ IL- $1 \beta$ resultou em aumento na expressão de gp38 de $2,6 \times 10^{3}$ para $3,4 \times 10^{3}$ nas DNCs e de $19,2 \times 10^{3}$ para $30,8 \times 10^{3}$ nas FRCs às 24

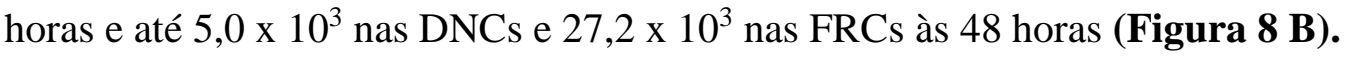

Já na amostra de doador de fígado em resposta ao tratamento com IFN- $\gamma$ as 24 horas o MFI aumentou de 2,4 x $10^{3}$ para 3,2 x $10^{3}$, nas DNCs e de 7,5 x $10^{3}$ para 8,9 x $10^{3}$ nas FRCs; às 48 horas para $3,0 \times 10^{3}$ nas DNCs e $15,0 \times 10^{3}$ nas FRCs. O tratamento com TNF- $\alpha+$ IL- $1 \beta$ resultou em aumento na expressão de 2,4 x $10^{3}$ para 3,2

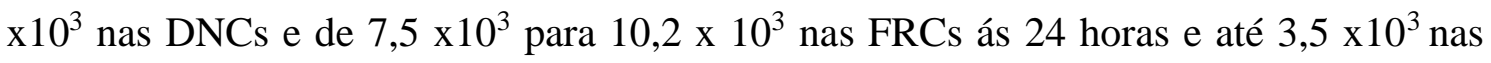
DNCs e 11,6 x10 $0^{3}$ nas FRCs ás 48 horas (Figura 8 C). 

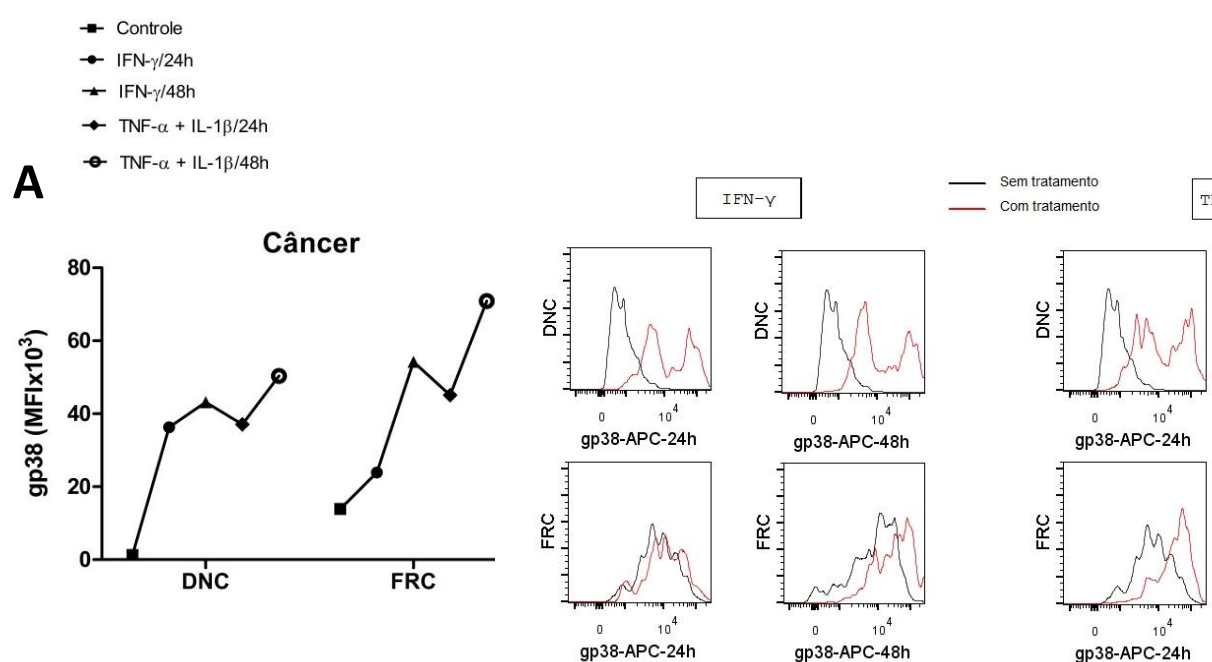

TNF- $\alpha+\mathrm{IL}-1 \beta$

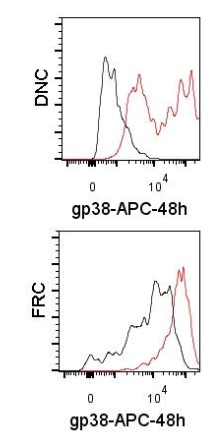

B
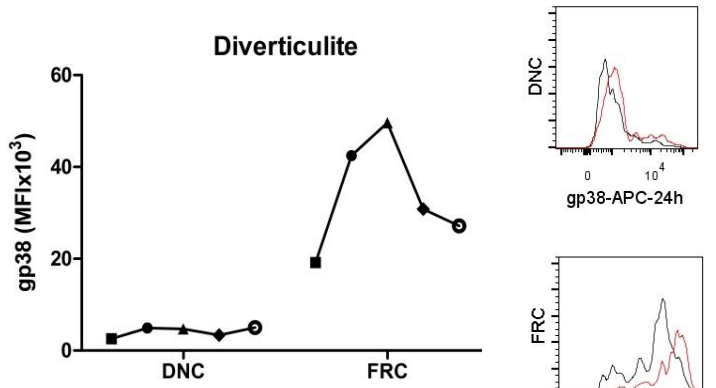

$$
\text { IFN-Y }
$$
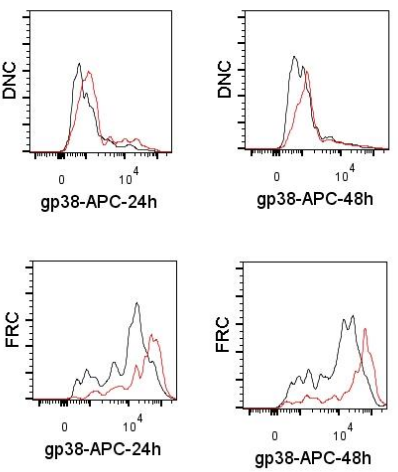

— Sem tratamento

$\mathrm{TNF}-\alpha+\mathrm{IL}-1 \beta$
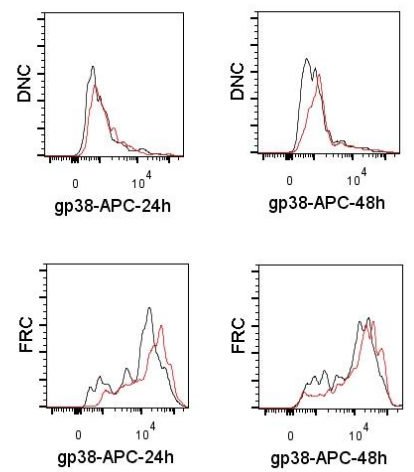

C

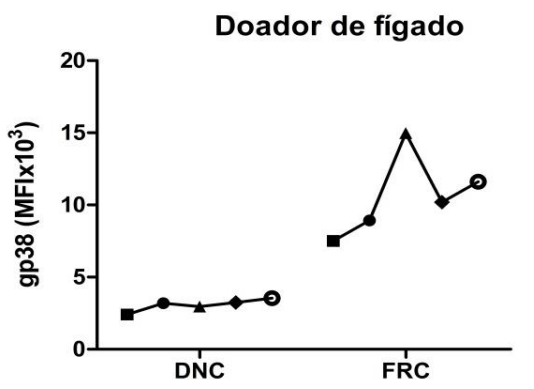

\section{IFN-Y}

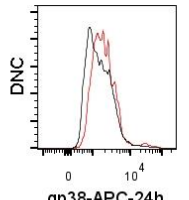

gP38-APC-24h

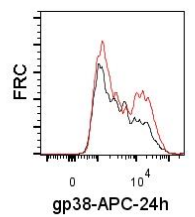

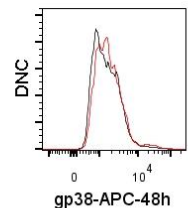

- Sem tratamento
com tratamento $\quad$ TNF- $\alpha+\mathrm{IL}-1 \beta$
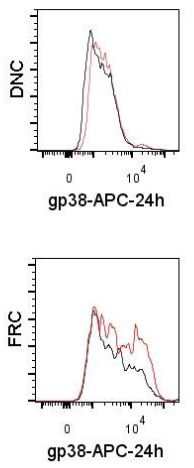
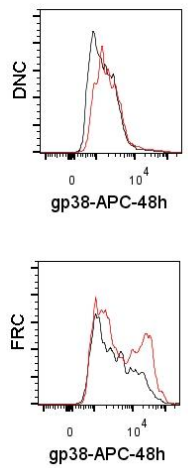

Figura 8. Expressão de gp38 após tratamento com IFN- $\gamma$ e TNF- $\alpha$ + IL-1ß. FRCs e DNCs foram previamente isoladas de LNs de pacientes com câncer ou com diverticulite, cultivadas e tratadas ou não (controle) com IFN- $\gamma$ ou TNF- $\alpha+$ IL-1 $\beta$ por 24 ou 48 horas. Intensidade média de fluorescência (MIF) e histograma representativo da expressão de gp38 nas DNCs e FRCs, nas duas condições. (A) amostra de câncer; (B) diverticulite e (C) doador de fígado. 


\subsection{Curva de expressão de gp38 nas FRCs}

Estudos em camundongos descrevem várias funções da molécula gp38, sugerindo seu uso como marcador de ativação nas FRCs (Yang et al, 2013).

Para determinar o período em que o aumento da expressão do gp38 se mantém, FRCs em cultura foram estimuladas com TNF- $\alpha+$ IL-1 $\beta$ por até 48 horas, passado esse tempo, foi retirado o meio contendo o estímulo e substítiudo por meio sem estímulo (Dia 0).

Avaliamos a expressão de gp38 às 24 e 48 horas após o estímulo e depois de retirado o estímulo, nos dias $1,2,4$ e 5 .

A expressão de gp38 foi mensurada de acordo com a média de intensidade de fluorescência (MFI) das amostras As FRCs não estimuladas (Controle) apresentaram o MFI de $27,1 \times 10^{3}$, às 24 horas, que aumentou para $35,5 \times 10^{3}$, com um pico de $68,4 \times$ $10^{3}$ às 48 horas, diminuindo para $40,4 \times 10^{3}$ no dia 1 após a retirar o estímulo inflamatório, com um leve aumento para $45,4 \times 10^{3}$ no segundo dia; $32,1 \times 10^{3}$ no dia 4 e por último $32,1 \times 10^{3}$ no dia 5 (Figura 9).

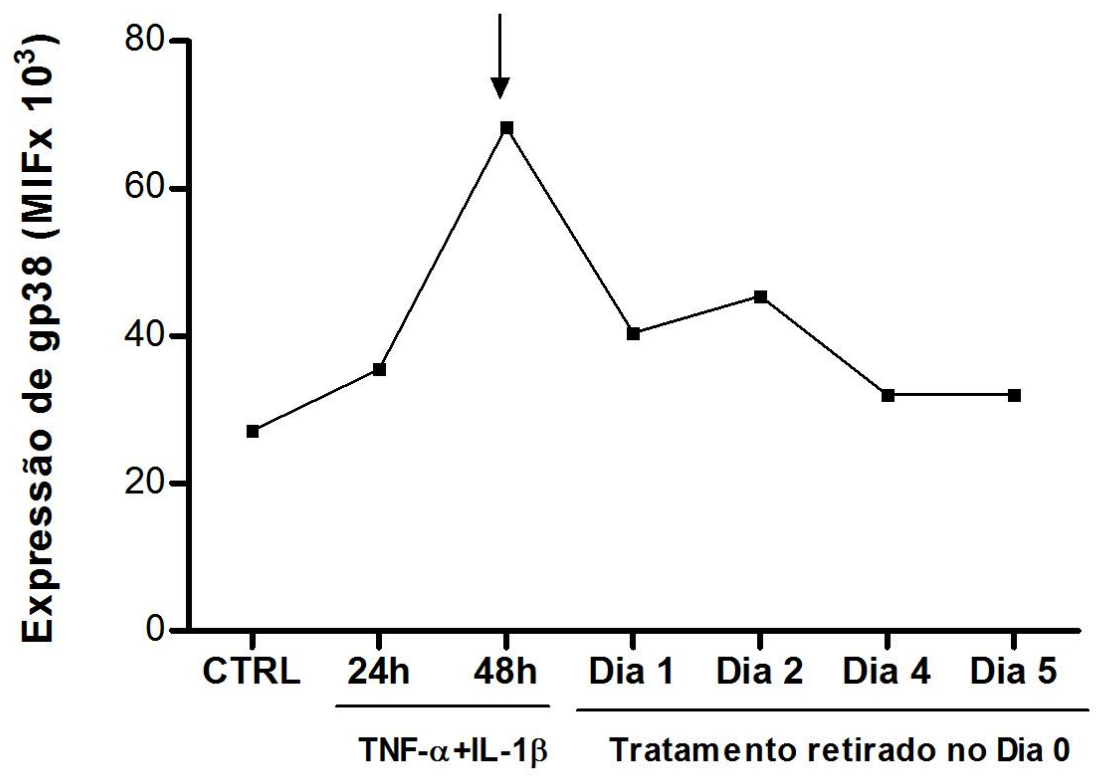

Figura 9. Curva de expressão de gp38 após estímulo inflamatório. FRCs foram cultivadas, quando confluentes foram estimuladas com TNF- $\alpha+$ IL-1 $\beta$ por 24 ou 48 horas. Depois desse tempo foi retirado o meio contendo o estímulo (Dia 0) e deixou-se em cultura até o dia 5. Posteriormente, por citometria de fluxo, avaliamos a média de intensidade de fluorescência da expressão de gp38, nas células não tratadas (CTRL) e tratadas com TNF- $\alpha+$ IL-1 $\beta$, às 24, 48 horas (seta) e nos dias 1, 2, 4, 5 depois de retirado o estímulo. 


\subsection{Estímulo inflamatório induz aumento na secreção de quimiocinas pelas FRCs e DNCs}

Nós observamos que os estímulos inflamatórios IFN- $\gamma$ ou TNF- $\alpha+$ IL-1 $\beta$ induzem superexpressão de genes para quimiocinas nas FRCs e DNCs.

Para confirmar se tais estímulos induzem além da expressão gênca, também a secreção de quimiocinas pelas células estromais de linfonodos, nós mensuramos a quantidade de CXCL8, CXCL12, CCL2, CCL19 e CCL20 no sobrenadante das culturas de FRCs e DNCs, estimuladas ou não (controle) com citocinas inflamatórias por 48 horas.

Nossos resultados evidenciam aumento significativo $(\mathrm{p}<0,05)$ na secreção de CCL2 pelas DNCs após o tratamento com TNF- $\alpha+\mathrm{IL}-1 \beta(12677 \pm 2178$ pg/mL) comparado com o grupo controle $(587 \pm 141 \mathrm{pg} / \mathrm{mL})$. Após tratamento com IFN- $\gamma$ não houve diferença significativa na secreção de CCL2 pelas DNCs em relação ao grupo controle, portanto, o estímulo com TNF- $\alpha+\mathrm{IL}-1 \beta$ induziu maior secreção de CCL2 pelas DNCs quando comparado ao estímulo com IFN- $\gamma(\mathrm{p}<0,05)$ (Figura 10A).

Similarmente, observamos um aumento significativo $(\mathrm{p}<0,001)$ na secreção de CCL2 pelas FRCs após estímulo com TNF- $\alpha+\mathrm{IL}-1 \beta(26050 \pm 6304$ pg/mL) em relação ao grupo controle $(912 \pm 139 \mathrm{pg} / \mathrm{mL})$. O tratamento com IFN- $\gamma$ também não induziu aumento na secreção de CCL2 pelas FRCs em relação ao grupo não estimulado. Mais uma vez observamos uma diferença significativa entre os dois tratamentos $(p<0,001)$ (Figura 10A).

A secreção de CCL20 aumentou significativamente $(\mathrm{p}<0,001)$ nas FRCs após estímulo com TNF- $\alpha+\mathrm{IL}-1 \beta(610 \pm 176 \mathrm{pg} / \mathrm{mL})$ comparado com o grupo controle $(14 \pm 3 \mathrm{pg} / \mathrm{mL})$ e com o tratamento com IFN- $\gamma(13 \pm 2 \mathrm{pg} / \mathrm{mL})$ (Figura 10B).

Em contrapartida, não se observou diferença na secreção da quimiocina CXCL12 pelas DNCs nem pelas FRCs, após estímulo inflamatório (Figura 10C).

Em relação à secreção de CXCL8/IL-8, apenas o tratamento com TNF- $\alpha+$ IL-1 $\beta$ induziu aumento significativo $(\mathrm{p}<0,001)$ na produção da quimiocina, tanto nas DNCs 
quanto nas FRCs. As DNCs sem tratamento produziram em média 4,4 $\pm 0,4 \mathrm{pg} / \mathrm{mL}$ de CXCL8, enquanto as tratadas com TNF- $\alpha+$ IL-1 $\beta, 73,5 \pm 2,5 \mathrm{pg} / \mathrm{mL}$. O tratamento com IFN- $\gamma$ não alterou a síntese de CXCL8 em relação ao controle. Similarmente, nas FRCs a produção de CXCL8 foi de 10,2 $\pm 4,9 \mathrm{pg} / \mathrm{mL}$ (Controle) para 78,4 $\pm 2,6 \mathrm{pg} / \mathrm{mL}$ após tratamento com TNF- $\alpha+$ IL-1 $\beta$; e não houve alteração quando tratada com IFN- $\gamma$ (Figura 10D).

Em relação à quimiocina CCL19, a secreção por DNCs e FRCs, em condições de homeostase e após estímulos inflamatórios, foi indetectável.

Esses dados sugerem que tanto as FRCs quanto as DNCs podem estar envolvidas no homing e posicionamento das diferentes células do sistema imune em condições homeostáticas e inflamatórias.

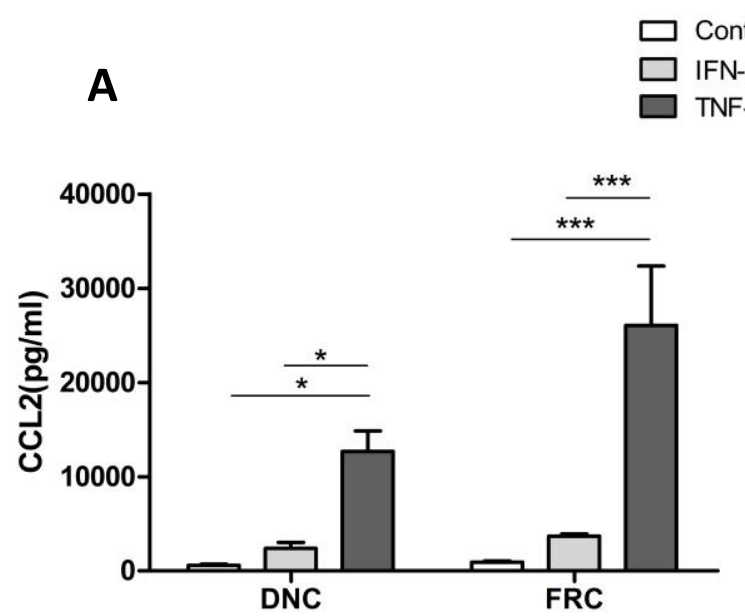

$$
\text { C }
$$
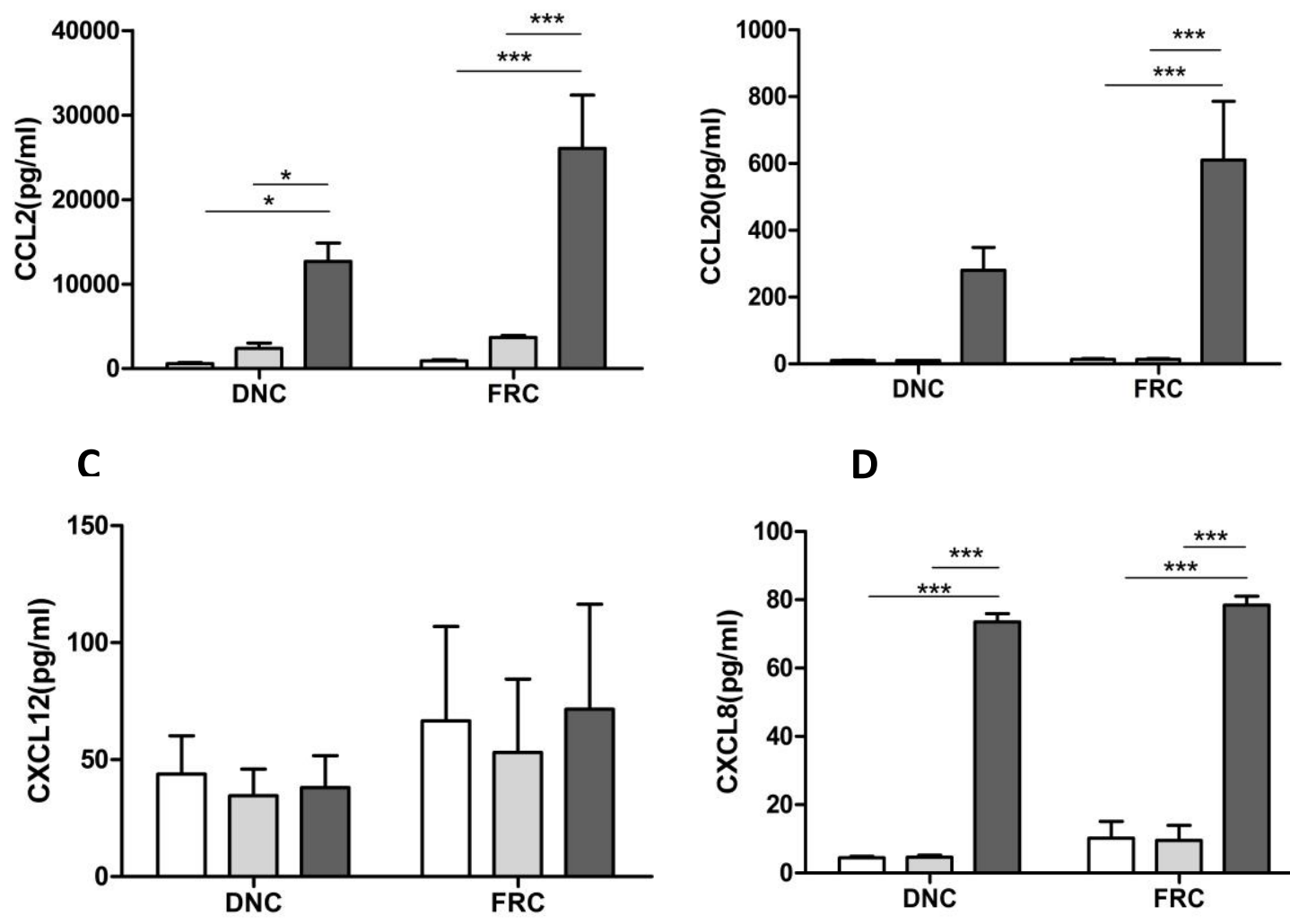

D

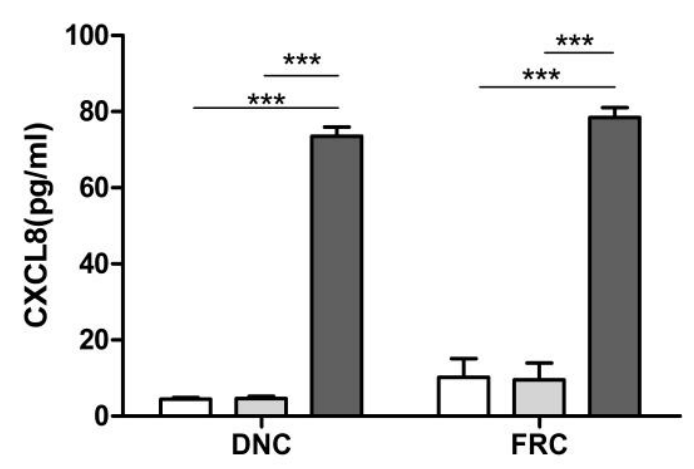

Figura 10. Secreção de quimocinas pelas FRCs e DNCs após tratamento com IFN- $\gamma$ ou TNF- $\alpha+$ IL13. DNCs e FRCs isoladas de LNs humanos foram colocadas em cultura e, quando confluentes, estimuladas com IFN- $\gamma$ ou TNF- $\alpha+$ IL-1 $\beta$. O sobrenadante das culturas sem estímulo (Controle) e após 
tratamento foi coletado e pela técnica de ELISA avaliou-se a secreção das quimiocinas (A) CCL2, (B) CCL20, (C) CXCL12 e (D) CXCL8. Mostra-se em branco quando não tratadas (Controle), em cinza claro quando tratadas com IFN- $\gamma$ e em cinza escuro quando tratadas com TNF- $\alpha+$ IL-1 $\beta$. (n=4).*p<0,05 $* * * \mathrm{p}<0,001$.

\subsection{Estímulo inflamatório contribui para secreção de citocinas pelas DNCs e FRCs}

Avaliamos a influência de estímulos inflamatórios sobre a síntese de citocinas por ambas as populações de células estromais isoladas de LNs humanos. Portanto, após 48 horas de tratamento com as citocinas inflamatórias, IFN- $\gamma$ ou TNF- $\alpha+$ IL- $1 \beta$, mensuramos a produção das citocinas IL-6, IL-7 e IL-10, pela técnica de ELISA, do sobrenadante de cultura de DNCs e FRCs.

Nós observamos que a produção de IL-6 pelas DNCs apresentou aumento significativo $(\mathrm{p}<0,05)$ após o tratamento com TNF- $\alpha+\operatorname{IL}-1 \beta(54,8 \pm 15,2 \mathrm{pg} / \mathrm{mL})$ comparado com o controle $(7,6 \pm 0,9 \mathrm{pg} / \mathrm{mL})$ ou com o grupo tratado com IFN- $\gamma$ $(10,7 \pm 1,2$ pg/mL). Não observamos diferença na produção de IL-6 pelas FRCs (Figura 11A).

Nas culturas de FRCs observamos que, após estímulo com IFN- $\gamma$ ou TNF- $\alpha+$ IL-1 $\beta$, houve aumento na produção de IL-7 $(5,7 \pm 1,0 \mathrm{pg} / \mathrm{mL})(\mathrm{p}<0,05)$ comparado ao o controle $(2,7 \pm 0,7 \mathrm{pg} / \mathrm{mL})$. Não se observou diferença na produção de IL-7 pelas DNCs nas diferentes condições de cultivo (Figura 11B).

A produção de IL-10 pelas DNCs ou FRCs foi quase indetectável em repouso e não foi alterada após estímulos inflamatórios (Figura 11C).

Em conjunto nossos dados sugerem a influência das duas populações de células no microambiente de citocinas dentro do linfonodo, nas duas condições: de homeostase e inflamação. 


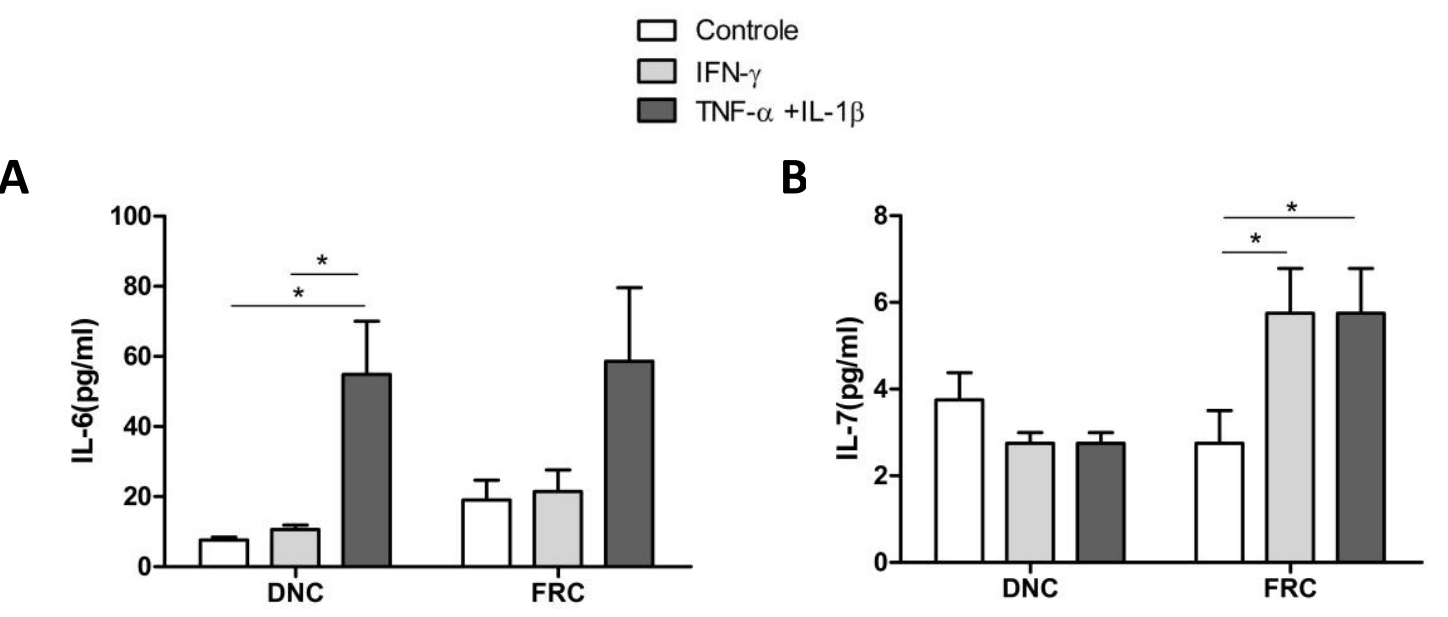

C

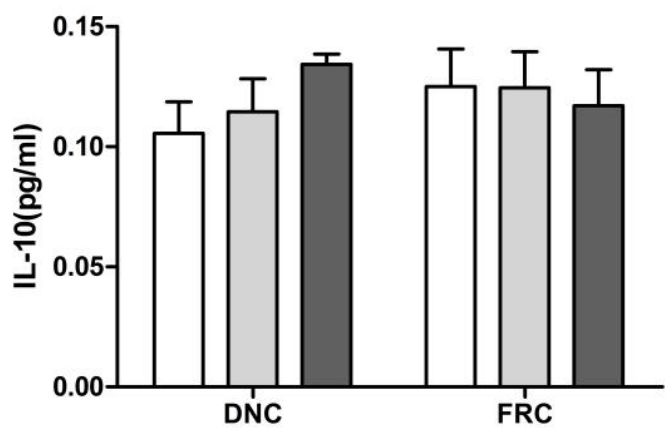

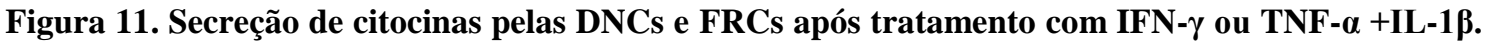

DNCs e FRCs isoladas de LNs humanos foram colocadas em cultura e, quando confluentes, estimuladas com IFN- $\gamma$ ou TNF- $\alpha+$ IL-1 $\beta$. O sobrenadante das culturas sem estímulo (Controle) e após estímulo foi coletado e pela técnica de ELISA avaliou-se a secreção das citocinas (A) IL-6, (B) IL-7 e (C) IL-10. Mostram-se em branco as células sem tratamento (Controle), em cinza claro após tratamento com IFN- $\gamma$ e em cinza escuro tratadas com TNF- $\alpha+\mathrm{IL}-1 \beta$. $(\mathrm{n}=4)$. ${ }^{\mathrm{p}} \mathrm{p}<0,05 * * * \mathrm{p}<0,001$ 


\subsection{DNCs e FRCs alteram a expressão de moléculas de superfície envolvidas na resposta imune após estímulo inflamatório}

Em condições inflamatórias, tanto nas DNCs quanto nas FRCs, observou-se superexpressão de genes que codificam para moléculas de superfície celular com função na resposta imune como CD40, CD83, PD-L1, HLA-ABC e HLA-DR.

Para verificar se o estímulo inflamatório poderia alterar a expressão de moléculas de superfície envolvidas na resposta imune, as culturas de DNCs e FRCs foram tratadas com IFN- $\gamma$ ou TNF- $\alpha+$ IL- $1 \beta$ por 48 horas. Verificamos a expressão de CD40, CD83, HLA-I (HLA-ABC) e HLA-DR, pela variação do MFI, por citometria de fluxo.

Em relação à expressão de CD40, não se observou diferença nas DNCs nem FRCs quando tratadas com IFN- $\gamma$ ou TNF- $\alpha+$ IL-1 $\beta$ quando comparados com seus respectivos controles (Figura 12).

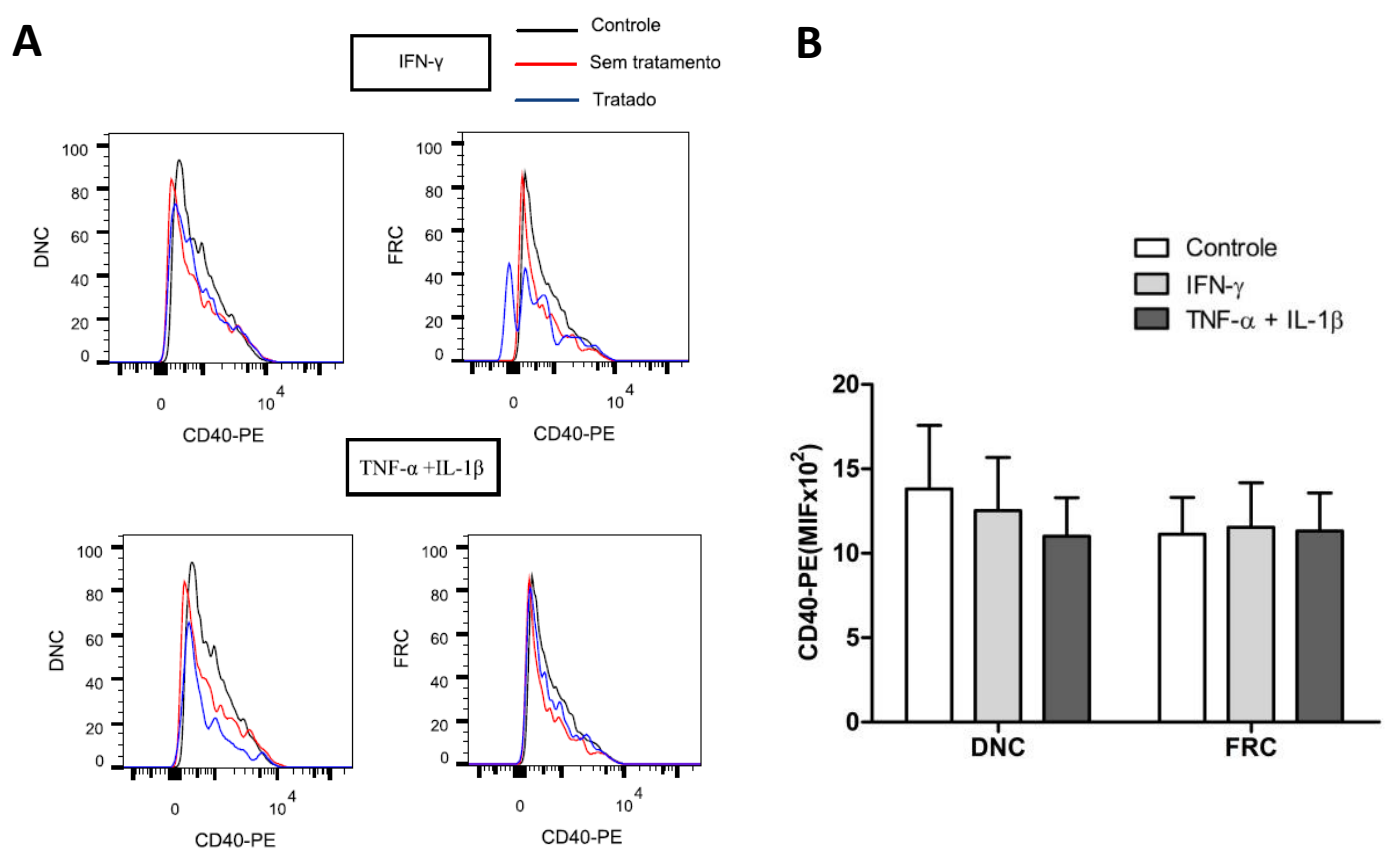

Figura 12. Expressão de CD40 nas DNCs e FRCs após estímulo inflamatório com IFN- $\gamma$ ou TNF-a + IL-1及. FRCs e DNCs, isoladas de LNs humanos, foram colocadas em cultura e, quando confluentes, estimuladas com IFN- $\gamma$ ou TNF- $\alpha+$ IL-1 $\beta$, por 48 horas. Posteriormente, por citometria de fluxo, avaliouse a variação da média de intensidade de fluorescência para o marcador CD40 nas duas condições. (A) Histograma representativo da expressão de CD40 nas DNCs e FRCs no grupo controle (não marcado, linha preta), sem tratamento (linha vermelha), tratado (linha azul) com IFN- $\gamma$ ou TNF- $\alpha+$ IL-1 $\beta$. (B) Média da intensidade de fluorescência da expressão de CD40 para DNCs e FRCs, sem tratamento 
(Controle, em branco), tratado com IFN- $\gamma$ (cinza claro) e com TNF- $\alpha+$ IL-1 $\beta$ (cinza escuro) $(n=5) . * p<0,05$.

Similarmente, em relação à expressão de CD83 não houve diferença nas DNCs nem FRCs após estímulos, comparado com o controle. (Figura 13).

A
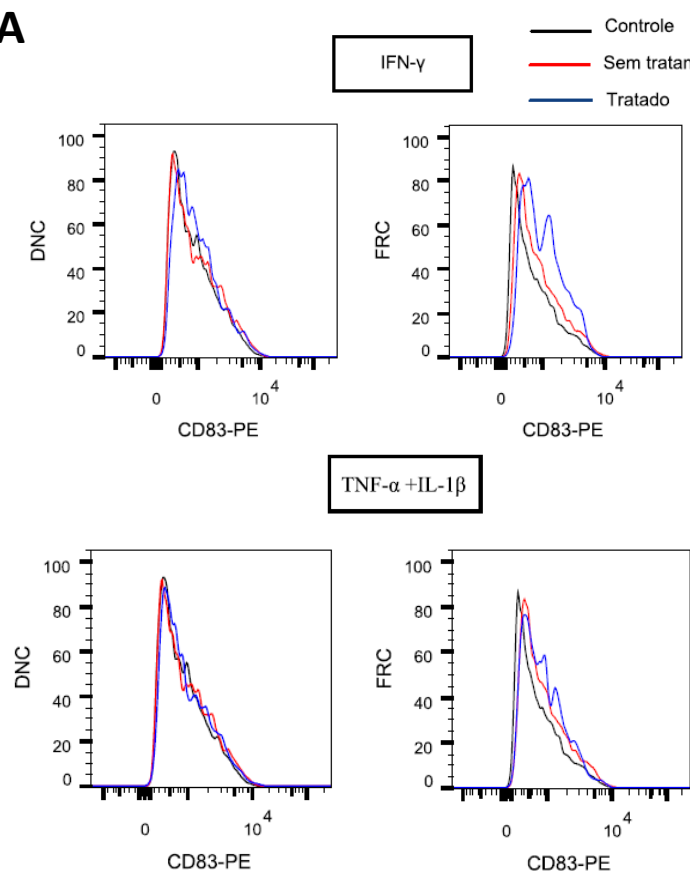

B
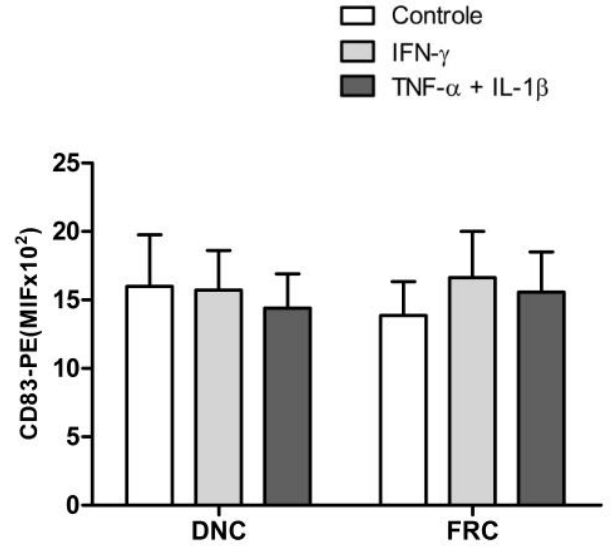

Figura 13. Expressão de CD83 nas DNCs e FRCs após estímulo inflamatório com IFN- $\gamma$ ou TNF-a

+ IL-1ß. FRCs e DNCs, isoladas de LNs humanos, foram colocadas em cultura e, quando confluentes, estimuladas com IFN- $\gamma$ ou TNF- $\alpha+$ IL-1 $1 \beta$, por 48 horas. Posteriormente, por citometria de fluxo, avaliouse a variação da média de intensidade de fluorescência para o marcador CD83 nas duas condições. (A) Histograma representativo da expressão de CD83 nas DNCs e FRCs no grupo controle (não marcado, linha preta), sem tratamento (linha vermelha), tratado (linha azul) com IFN- $\gamma$ e TNF- $\alpha+$ IL-1 $\beta$. (B) Média da intensidade de fluorescência da expressão de CD83 para DNCs e FRCs, sem tratamento (Controle, em branco), tratado com IFN- $\gamma$ (cinza claro) e com TNF- $\alpha+$ IL-1 $\beta$ (cinza escuro) $(\mathrm{n}=5) \cdot * \mathrm{p}<0,05$.

Adicionalmente, verificamos se houve alteração na expressão das moléculas de HLA-ABC. Observamos que esta molécula é mais expressa na membrana de DNCs e FRCs, quando tratadas com IFN- $\gamma$ em relação ao controle e comparado às células tratadas com TNF- $\alpha+$ IL- $1 \beta$. Nas DNCs, a MFI foi de $5,2 \pm 0,7 \times 10^{3}$ no grupo controle, $33,9 \pm 6,7 \times 10^{3}$ após tratamento com IFN- $\gamma$ e 10,2 $\pm 2,1 \times 10^{3}$ após estímulo com TNF- $\alpha+$ IL-1 $\beta$. Já nas FRCs a MFI foi de 5,2 $\pm 0,6 \times 10^{3}$ no grupo controle, 39,5 $\pm 4,1 \times 10^{3}$ nas tratadas com IFN- $\gamma$ e 10,9 $\pm 3,1 \times 10^{3}$ após tratamento com TNF- $\alpha+$ IL-1 $\beta$ (Figura 14). 
A
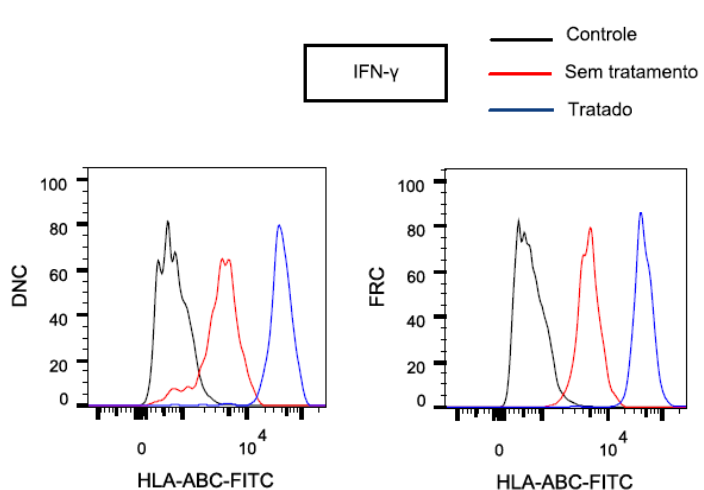

TNF- $\alpha+\mathrm{IL}-1 \beta$
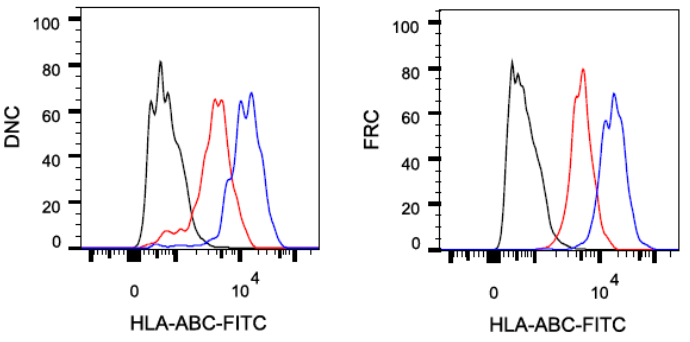

B

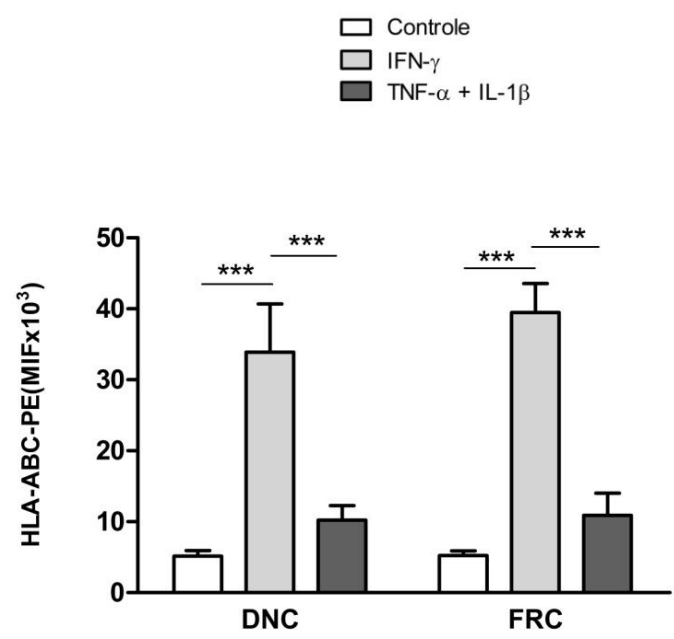

Figura 14. Expressão de HLA-ABC nas DNCs e FRCs após estímulo inflamatório com IFN- $\boldsymbol{\gamma}$ ou TNF- $\boldsymbol{\alpha}+$ IL-1ß. FRCs e DNCs, isoladas de LNs humanos, foram colocadas em cultura e, quando confluentes, estimuladas com IFN- $\gamma$ ou TNF- $\alpha+$ IL-1 $\beta$, por 48 horas. Posteriormente, por citometria de fluxo, avaliou-se a variação da média de intensidade de fluorescência para o marcador HLA-ABC nas duas condições. (A) Histograma representativo da expressão de HLA-ABC nas DNCs e FRCs no grupo controle (não marcado, linha preta), sem tratamento (linha vermelha), tratado (linha azul) com IFN- $\gamma$ e TNF- $\alpha+$ IL-1 $\beta$. (B) Média da intensidade de fluorescência da expressão de HLA-ABC para DNCs e FRCs, sem tratamento (Controle, em branco), tratado com IFN- $\gamma$ (cinza claro) e com TNF- $\alpha+$ IL-1 $\beta$ (cinza escuro) $(\mathrm{n}=4)$. $* * * \mathrm{p}<0,001$.

Verificamos também a expressão de superfície da molécula do HLA-DR e observamos que houve aumento na expressão desta molécula em resposta ao estímulo com IFN- $\gamma$, quando comparado com o controle, em ambas as populações celulares. Nas

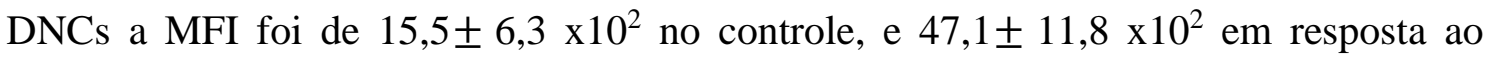

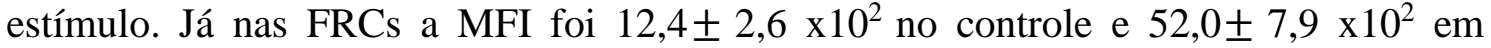
resposta ao estímulo (Figura 15). Nossos resultados sugerem que as DNCs e FRCs atuam no início e regulação da resposta imune, de acordo com os estímulos recebidos e de acordo com seu estado de ativação. 


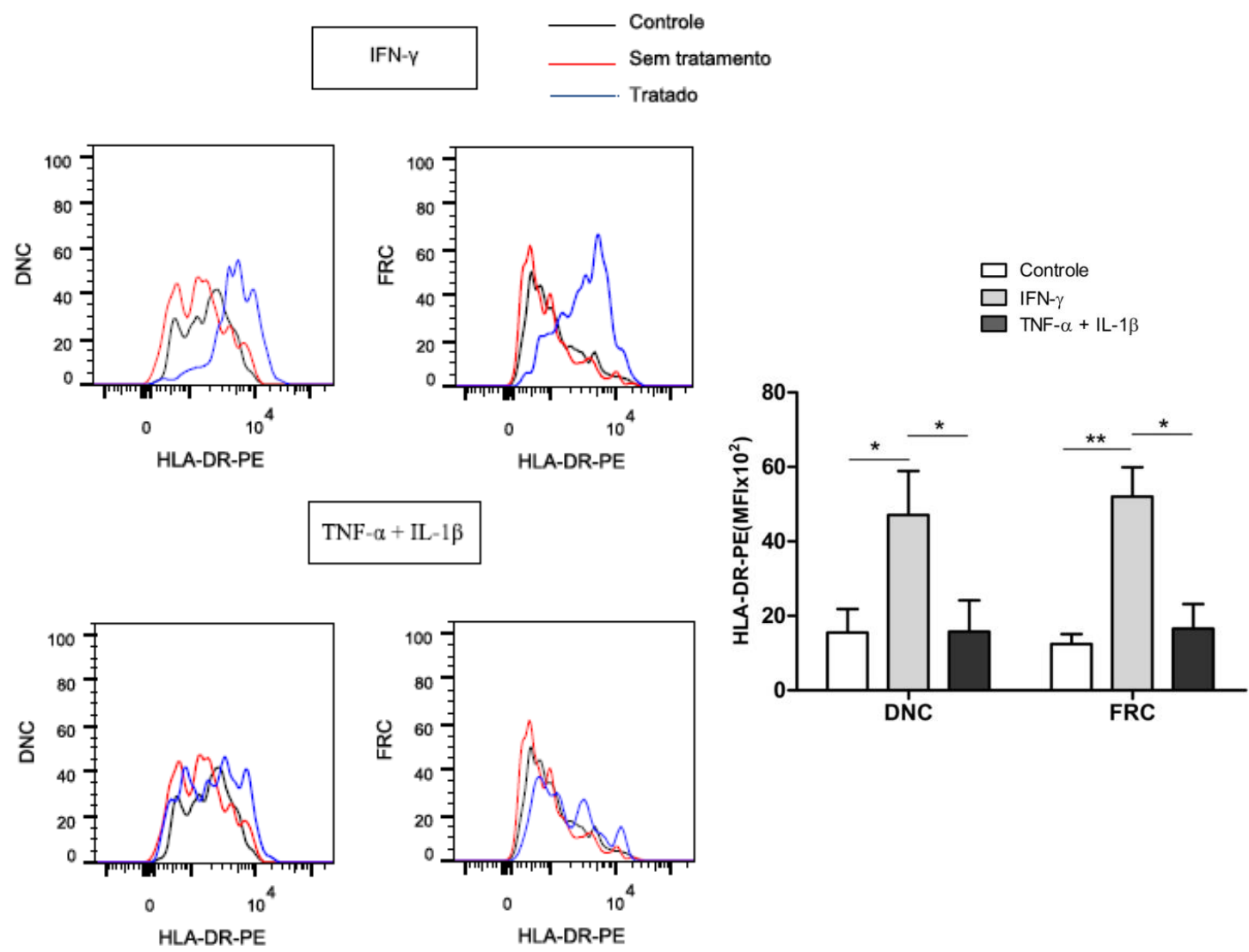

Figura 15. Expressão de HLA-DR nas DNCs e FRCs após estímulo inflamatório com IFN- $\gamma$ ou

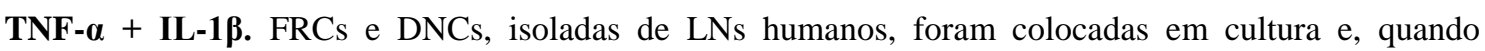
confluentes, estimuladas com IFN- $\gamma$ ou TNF- $\alpha+$ IL-1 $\beta$, por 48 horas. Posteriormente, por citometria de fluxo, avaliou-se a variação da média de intensidade de fluorescência para o marcador HLA-DR. (A) Histograma representativo da expressão de HLA-DR nas DNCs e FRCs no grupo controle (não marcado, linha preta), sem tratamento (linha vermelha), tratado com IFN- $\gamma$ ou TNF- $\alpha+$ IL-1 $\beta$ (linha azul). (B) Média da intensidade de fluorescência da expressão de HLA-DR para DNCs e FRCs, sem tratamento (Controle, em branco), tratado com IFN- $\gamma$ (cinza claro) e tratado com TNF- $\alpha+$ IL-1 $\beta$ (cinza escuro) $(\mathrm{n}=5) * \mathrm{p}<0,05 ; * * \mathrm{p}<0,01$.

Do mesmo modo, para verificar a alteração da expressão da molécula CD274 ou PD-L1, nas DNCs e FRCs, as culturas foram tratadas com a citocina inflamatória IFN- $\gamma$ por 48 horas. Observou-se nas duas populações aumento significativo $(\mathrm{p}<0,001)$ na 
expressão de PD-L1 após estímulo. Para as DNCs a MFI foi de 10,7 $\pm 2,4 \times 10^{2}$ sem tratamento e $24,7 \pm 4,1 \times 10^{2}$ após tratamento. Similarmente as FRCs sem tratamento apresentaram MFI de 10,7 $\pm 1,9 \times 10^{2}$ e $27,1 \pm 3,1 \times 10^{2}$ após tratamento com IFN- $\gamma$ (Figura 16).

A

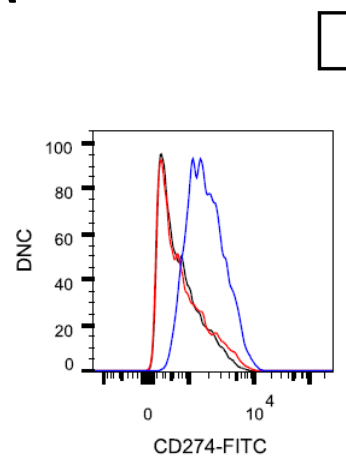

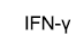$$
\text { IFN-Y }
$$$$
\text { Controle }
$$$$
\text { Sem tratamento }
$$$$
\text { Tratado }
$$

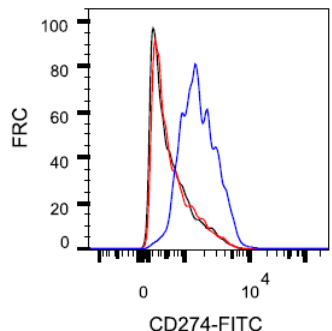

B $\square$ Controle $\square$ IFN- $\gamma$

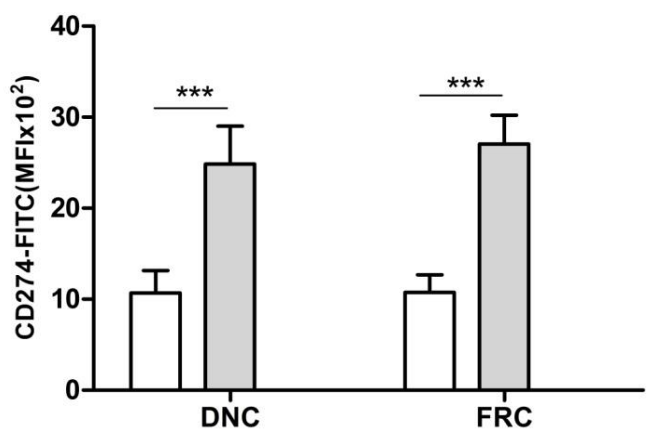

Figura 16. Expressão de CD274 nas DNCs e FRCs após estímulo inflamatório com IFN- $\gamma$. FRCs e DNCs, isoladas de LNs humanos, foram colocadas em cultura e, quando confluentes, estimuladas com IFN- $\gamma$, por 48 horas. Posteriormente, por citometria de fluxo, avaliou-se a variação da média de intensidade de fluorescência para o marcador CD274. (A) Histograma representativo da expressão de CD274 nas DNCs e FRCs no grupo controle (não marcado, linha preta), sem tratamento (linha vermelha), tratado com IFN- $\gamma$ (linha azul). (B) Média da intensidade de fluorescência da expressão de CD274 para DNCs e FRCs, sem tratamento (Controle, em branco) e tratado com IFN- $\gamma$ (cinza claro) $(\mathrm{n}=5) . * * * \mathrm{p}<0,001$. 


\section{DISCUSSÃO}

As populações de células estromais presentes nos LNs humanos, DNCs e FRCs, expressam diversas moléculas com função tanto de induzir quanto de controlar a imunidade em resposta aos estímulos inflamatórios IFN- $\gamma$ e TNF- $\alpha+$ IL1 $\beta$.

Originalmente, as células estromais presentes nos LNs murinos foram descritas como células com papel estrutural dentro do órgão, porém, estudos atuais apresenteram indícios de que estas populações celulares estejam envolvidas, diretamente ou por interações com outras células presentes no LN, na indução e na regulação da resposta imune. Contudo, são escassos os trabalhos científicos que avaliam as diferentes funções imunológicas das células estromais de LNs na espécie humana.

Para este estudo, obtivemos LNs de pacientes com câncer, diverticulite que foram submetidos a procedimentos cirúrgicos e doadores de fígado. A organização morfológica dos LNs obtidos para este estudo foi analisada, com o intuito de utilizarmos apenas os órgãos sem alterações metastáticas.

Isolamos e caracterizamos imunofenotipicamente duas populações de células estromais presentes nos LNs humanos: DNCs (gp38, $\left.\mathrm{CD} 31^{-}\right)$e FRCs (gp38 $\left.{ }^{+}, \mathrm{CD}^{-} 1^{-}\right)$. Uma vez identificado o perfil imunofenotípico das DNCs e FRCs, conseguimos, com sucesso, separar fisicamente estas duas populações celulares, com alta pureza, de modo similar a estudos prévios (Vega et al, 2006; Fletcher et al, 2010).

Segundo dados anteriores da literatura, em condições de homeostase, as FRCs constituem cerca de 20-50\% do compartimento estromal nos LNs murinos (Fletcher et al, 2015), enquanto as DNCs, 5-10\% (Fletcher et al, 2010). Observamos diferenças na frequência de DNCs e FRCs isoladas dos LNs humanos, as quais podem estar relacionadas tanto ao tipo de doença quanto aos órgãos dos quais derivam esses LNs. Nos LNs obtidos de doadores de fígado, tanto as DNCs quanto as FRCs encontraram-se em porcentagens similares (50\%), todavia, nos LNs de câncer, as FRCs representaram $40 \%$, enquanto na diverticulite, $80 \%$ das células estromais isoladas. Provavelmente, as FRCs estejam contribuindo para a manutenção do perfil inflamatório nos LNs, uma vez que se apresentaram em maior número em relação às DNCs de pacientes com doença inflamatória. 
Ao avaliarmos a expressão de genes relacionados com a indução e com o controle da proliferação celular, notamos uma relevante diferença entre as DNCs e as FRCs na ausência de estímulos inflamatórios. Durante o cultivo dessas células, verificamos que as FRCs apresentaram maiores taxas proliferativas em relação às DNCs. Astarita e colaboradores (2015) demonstraram a influência da via de sinalização da proteína gp38 (PDPN) na sobrevivência e proliferação normal das FRCs murinas. Inclusive, a ausência de PDPN acarretou no aumento no número dessas células comparadas aos controles em condições homeostáticas. Em contraste, nossos dados sugerem que, nas mesmas condições, as FRCs possuem alta expressão gênica e protéica para PDPN, e isso está relacionado com um maior potencial de proliferação quando comparadas com as DNCs que não expressam PDPN.

Transcritos para outras duas citocinas, IL-6 e IL-21, também relacionadas com proliferação de células imunes, foram superexpressos em condições homeostáticas nas FRCs, contrário ao que verificamos nas DNCs. A IL-21 pode afetar a diferenciação, proliferação e função de células $\mathrm{T}$ e $\mathrm{B}$, além de induzir maturação e aumento da citotoxicidade das células TCD8 ${ }^{+}$e NK. Já a IL-6 apresenta um papel importante na proliferação e indução de citotoxicidade de células $\mathrm{T} C D 8^{+}$, contribuindo para a síntese de IL-21. Juntas, a IL-6 e a IL-21, podem inibir a expressão do fator de transcrição FoxP3, regulando a diferenciação de células Treg e favorecendo o desenvolvimento de células Th17 (Lee et al, 2016; Gharibi et al, 2016).

Células estromais presentes nos linfonodos, incluindo DNCs e FRCs, são capazes de responder a vários estímulos como TNF- $\alpha$, LPS, IFN- $\gamma$, IL-6, IL-4, IL-13 e antígenos virais, mudando a expressão de diversas moléculas envolvidas na resposta imune (Katakai et al, 2004; Vega et al, 2006; Siegert e Luther, 2012; Yang et al, 2013).

O IF N- $\gamma$ é uma citocina produzida por células $\mathrm{T} \mathrm{CD} 4^{+}, \mathrm{CD}^{+}, \mathrm{NK}$, entre outras, em resposta a estímulos inflamatórios. Induz o fenótipo Th1de linfócitos T, mediante a indução da expressão da proteína T-bet e supressão da proteína GATA3, que levaria ao fenótipo Th2. Além disso, inibe citocinas que induzem o fenótipo Th17 (Dorman e Holland, 2000). Em contrapartida, a citocina TNF- $\alpha$ é secretada por células T e B em resposta à estimulação antigênica, e principalmente por monócitos e macrófagos, quando seus receptores TLR são estimulados. Já a IL-1 $\beta$ participa de diversos processos imunológicos, incluindo a diferenciação das células T nos fenótipos Th1 e Th2 (Vega et 
$a l$, 2006). Adicionalmente, IL-1 $\beta$ é sintetizada durante a produção de TNF, influenciando a regulação do receptor de TNF (Saperstein et al, 2009). Com base nesses dados, avaliamos a expressão de moléculas envolvidas no processo imunológico em ambas as populações de células, DNCs e FRCs, quando tratadas com os estímulos inflamatórios IFN- $\gamma$ ou TNF- $\alpha+$ IL- $1 \beta$.

Em relação à expressão de gp38 nas populações de células estromais estudadas, ambos os estímulos induziram maior expressão dessa molécula na superfície das células avaliadas. Tal resultado foi similar apenas no tratamento com IFN- $\gamma$ quando avaliada a expressão gênica, visto que o aumento foi ainda mais significativo nas DNCs quando comparadas com seus respectivos controles. Tal aumento, contudo, apresentou diferenças entre as amostras. No caso das FRCs das amostras de câncer e diverticulite, quando estimuladas com IFN- $\gamma$ ou TNF- $\alpha$ + IL-1 $\beta$, a expressão protéica de gp38 aumentou em média 4 vezes. Em contraste, o aumento foi apenas 2 vezes na amostra de doador de fígado. Contudo, na amostra do LN proveniente de câncer, verificamos aumento de 33 vezes quando as DNCs foram estimuladas com IFN- $\gamma$ e 39 vezes em resposta ao TNF- $\alpha+$ IL-1 $\beta$. Na amostra proveniente de doença inflamatória, houve apenas o dobro de expressão de gp38 nas DNCs sob ambas condições inflamatórias. Já na amostra derivada de doador de fígado não observamos variação nas DNCs em resposta aos estímulos.

A diferença de expressão da proteína gp38 frente aos sinais inflamatórios supostamente seja devido ao microambiente de citocinas e aos diversos sinais imunológicos aos quais as DNCs e FRCs estão expostas nos LNs, nas diferentes doenças.

Vários estudos descrevem diversas funções para a molécula gp38 na indução da resposta imunológica. Em modelo murino, a imunização com OVA ou infecção viral induz aumento da expressão da proteína gp38, sugerindo que esta molécula possa ser utilizada como um marcador de ativação das FRCs, uma vez que seu aumento levou a outras alterações em moléculas de superfície (Yang et al, 2013). Adicionalmente, a molécula gp38, mediante a interação com seu receptor CLEC-2 expresso nas DCs, regula a formação de protrusões de membrana, contribuindo para a motilidade dessas células (Acton et al, 2012). Outro estudo identificou a proteína gp38 como o principal regulador da contratilidade das FRCs. Em condições de repouso, a via de sinalização da 
gp38 mantém as FRCs em estado de contração, enquanto na resposta inflamatória, a interação de FRCs com as DCs, e consequente ligação da gp38 com seu receptor CLEC2, resulta no bloqueio da gp38, o que leva ao relaxamento do citoesqueleto das FRCs. Esta mudança contribui no processo de remodelamento que sofre o LN em resposta aos diferentes estímulos (Astarita et al, 2015).

Pós 48 horas de estímulo com TNF- $\alpha$ + IL-1 $\beta$, a expressão de gp38 nas FRCs humanas aumentou significativamente, e diminuiu de modo gradativo na ausência de estímulo inflamatório, alcançando seu nível basal no quinto dia. Esse resultado corrobora o estudo de Yang e colaboradores (2013) no qual observou-se aumento de 200\% na expressão da proteína gp38 em FRCs murinas, dentro de 40 horas após imunização com OVA. Esse nível foi mantido até o dia 5, diminuindo até seu estado basal no oitavo dia.

Quimiocinas são citocinas quimiotáticas que controlam a migração e posicionamento das células imunes na homeostase e na inflamação (Griffith et al, 2014). As DNCs e as FRCs humanas estimuladas durante 24 horas com IFN- $\gamma$ ou TNF$\alpha+\mathrm{IL}-1 \beta$ apresentaram aumento na expressão de genes de diversas quimiocinas, dentre elas CCL2, CXCL8, CCL8, CCL5, CCL7, CXCL10. Trabalhos anteriores já haviam reportado a produção de algumas dessas quimiocinas por FRCs de camundongos (Malhotra et al, 2012), corroborando nossos dados.

Particularmente, a secreção de CCL2 pelas DNCs e FRCs aumentou de modo significativo apenas em resposta ao TNF- $\alpha+\mathrm{IL}-1 \beta$, quando comparadas a seus respectivos controles. A CCL2, proteína quimioatraente de monócitos-1 (do inglês monocyte chemoattractant protein-1, MCP-1), está envolvida na atração de monócitos, alguns subtipos de linfócitos e DCs, que expressam seu receptor CCR2. Além da função quimiotática, estudos recentes demonstram que a ligação CCR2/CCL2 está envolvida em outros processos como maturação de DCs e secreção de CCL19 por essas células (Jimenez et al, 2010).

Similar aos nossos achados, Vega e colaboradores (2006) verificaram expressão gênica de CCL2, 25 vezes maior nas FRCs obtidas de LNs humanos, quando estimuladas com TNF- $\alpha$. Outro estudo realizado por Malhotra e colaboradores (2012) 
reportou expressão inalterada de transcritos para CCL2 e CCL20 em FRCs e DNCs de camundongos, mesmo após estímulo com LPS.

A quimiocina CCL20, proteína $3 \alpha$ inflamatória de macrófagos - (do inglês macrophage inflammatory protein-3alpha, MIP-3 $\alpha$ ), pertence à família de quimiocinas C-C. Trata-se de uma quimiocinas que participa da atração de DCs imaturas, células T $\mathrm{CD}^{+}$efetoras e memória e de linfócitos $\mathrm{B}$, pela ligação com seu receptor CCR6 (Zhao et al, 2014). Em nosso estudo as FRCs responderam ao estímulo com TNF- $\alpha+$ IL-1 $\beta$ aumentando significativamente a produção proteica e dos transcritos para CCL20.

Por outro lado, a quimiocina CXCL12 está envolvida na entrada de células T naives e DCs nos LNs, mediante a ligação a seu receptor CXCR4 (Griffith et al, 2014). Corroborando com nossos dados, estudos mostraram a expressão de transcritos de CXCL12 nas FRCs e DNCs em condições homeostáticas (Fletcher et al, 2011; Malhotra et al, 2012), uma vez que observamos a produção de CXCL12 por ambas as populações em condição similar de cultivo. Porém, tal síntese não sofreu alteração quando as células foram estimuladas com IFN- $\gamma$ ou TNF- $\alpha+$ IL-1 $\beta$. Em contraste, Vega e colaboradores (2006) demonstraram que FRCs obtidas de LNs humanos, e estimuladas com TNF- $\alpha$, apresentaram aumento na expressão de genes que codificam CXCL12 após tratamento.

Quanto à expressão de transcritos para CXCL8, houve aumento apenas nas FRCs após 24 horas de tratamento com IFN- $\gamma$, porém não detectamos secreção desta quimiocina no sobrenadante das FRCs, às 48 horas. Já em resposta ao TNF- $\alpha+$ IL-1 $\beta$, nossos resultados mostram superexpressão de transcritos e aumento na secreção de CXCL8 nas DNCs e FRCs. Estudos em LNs humanos obtidos de linfomas também reportam aumentos de transcritos da quimiocina CXCL8 depois de tratar as FRCs com TNF- $\alpha$ (Vega et al, 2006). A CXCL8, também conhecida como IL-8, está envolvida no recrutamento de neutrófilos e alguns subtipos de células T (Griffith et al, 2014).

Além das quimiocinas já citadas, a CCL19 também participa da atração de células T, B e DCs para o interior do LN. Vários estudos feitos em camundongos relatam a secreção de CCL19 pelas FRCs (Malhotra et al, 2012; Yang et al, 2013). Entretanto, outro grupo descreveu que ao contrário das FRCs murinas recém-isoladas, as FRCs expressam baixos níveis de transcritos de CCL19 e CCL21 após cultivo in 
vitro (Siegert et al, 2011). Nossos ensaios, entretanto, não detectaram transcrição de CCL19, nem secreção da quimiocina no sobrenadante das culturas de DNCs ou FRCs.

Juntos esses dados sugerem que as DNCs e FRCs apresentam um papel importante no recrutamento e localização de células hematopoiéticas nos órgãos linfoides secundários em condições homeostáticas e em resposta a mediadores inflamatórios.

Dados da literatura indicam que as FRCs podem influenciar a resposta imune mediante a secreção de várias citocinas como IL-1 $\beta$, IL-6, IL-7 e TGF- $\beta$, em condições homeostáticas ou em resposta a estímulos inflamatórios (Vega et al, 2006, Link et al, 2007).

Após estímulo com IFN- $\gamma$, houve aumento na expressão de transcritos para IL-6, apenas nas DNCs. Enquanto, quando avaliamos a expressão protéica, observamos aumento na secreção de IL-6 por estas células unicamente após estímulo com TNF- $\alpha$ +IL-1 $\beta$. Vega e colaboradores (2006) também observaram aumento na expressão de genes que codificam IL-6, após estimular FRCs com TNF- $\alpha$. A IL-6 está envolvida na diferenciação de células TCD4+, favorecendo a polarização para o perfil Th17.

A IL-7 é fundamental para a homeostase de células T na periferia, fornece sinais antiapoptóticos para células T e DCs e favorece a proliferação de linfócitos dentro dos órgãos linfoides secundários (Onder et al, 2012). Estudos feitos em camundongos diferem nos dados em relação à produção de IL-7 pelas FRCs e DNCs. O estudo realizado por Malhotra e colaboradores (2012) mostrou expressão de transcritos de IL-7 em condições homeostáticas e superexpressão em condições inflamatórias pelas FRCs, mas não pelas DNCs. Entretanto, outro grupo não mostrou diferença na expressão gênica de IL-7 em células estromais de camundongos imunizados com OVA (Yang et $a l$, 2013). Link e colaboradores (2007) identificaram as FRCs como a principal fonte de IL-7 em LNs de camundongos naives. Nesse caso, a IL-7 e a quimiocina CCL19 contribuíram para a sobrevivência das células T dentro do linfonodo. Nós observamos pequena síntese de IL-7 pelas FRCs, que aumentou após os estímulos com IFN- $\gamma$ e TNF- $\alpha+$ IL-1 $\beta$.

A IL-10 é uma citocina anti-inflamatória que participa na inibição da atividade das células Th1, células NK e macrófagos, durante infecções (Couper et al, 2008). Similar ao reportado por outros estudos, nós não observamos aumento na produção de 
IL-10 pelas DNCs e FRCs após o tratamento com os estímulos inflamatórios (Vega et al, 2006; Malhotra et al, 2012).

O tratamento com IFN- $\gamma$ também contribuiu para o aumento da expressão de genes para outras citocinas como IL-15, IL-32 e IL-33, além de receptores de citocinas como: IFNAR2, IL31RA, IL15RA e IL3RA nas células estromais de LN. Particularmente, a IL-15, citocina proinflamatória com papel central no desenvolvimento, sobrevivência e ativação de células NK, T e B (Mishra et al, 2014), estava superexpressa somente nas FRCs.

O aumento na expressão gênica de IL-32 e IL-33 foi maior nas DNCs, quando comparado ao das FRCs. A IL-32 é sintetizada principalmente por células NK, T, células epiteliais e monócitos; apresenta função importante em infecções por diferentes patógenos, sendo essencial na resposta antiviral. Além disso, estimula a produção de várias outras citocinas e quimiocinas inflamatórias como TNF- $\alpha$, IL-1 $\beta$, IL-6, IL-8 e MIP-2 (Zhou e Zhu, 2015). Em contrapartida, a IL-33 é produzida principalmente por células epiteliais, endoteliais e do músculo liso. Durante o processo de necrose, a IL-33 é secretada e reconhecida principalmente por mastócitos, induzindo a produção de quimiocinas e citocinas que exacerbam processos alérgicos e inflamatórios (Saluja et al, 2015). Em contraste, no estudo de Malhotra e colaboradores (2012), a transcrição de IL33 induzida por LPS é aumentada unicamente nas FRCs de LNs murinos.

Adicionalmente, o tratamento com IFN- $\gamma$ aumentou, nas FRCs, a expressão do gene que codifica a proteína de ligação à IL-18 (do inglês, IL-18 binding protein IL18BP), sintetizada principalmente por células mononucleares. A IL-18BP solúvel se liga à IL-18, dificultando a ligação com seu receptor. Tal interação diminui a produção de IFN- $\gamma$ dependente de IL-18 e, por conseguinte, reduz o perfil Th1 de resposta imunológica (Dinarello et al, 2013).

Outro gene cuja expressão foi aumentada somente nas DNCs, em resposta ao IFN- $\gamma$, foi o gene 1 induzido por IL-4 (do inglês, Interleukin-4-induced gene 1 IL-4I1), uma L-fenilalanina oxidase. Esta enzima está especificamente associada às células Th17, e participa da via de sinalização do receptor TCR das Th17, inibindo a produção de IL-2, resultando, por sua vez, na inibição da proliferação e expansão destas células (Annunziato et al, 2013). 
Desse modo, podemos sugerir que DNCs e FRCs, além de apresentarem papéis fundamentais na manutenção da morfologia estrutural dos LNs, distinguem-se quanto à síntese de citocinas no microambiente desses órgãos, contribuindo também para a diferenciação de células $\mathrm{T}$.

A interação CD40-CD40L contribui para a regulação de uma variedade de processos da imunidade celular e humoral, como na ativação de células $\mathrm{T}$ mediada por DCs, proliferação de células B, síntese de imunoglobulinas, troca de isotipo e formação do centro germinativo (Hossein e Akbar, 2012). O CD40, membro da superfamília do receptor de TNF (do inglês, tumor necrosis factor receptor superfamily TNFR), pode estar constitutivamente expresso ou ser induzido na superfície de uma variedade de tipos celulares, incluindo células B, macrófagos, DCs, microglias, células endoteliais, epiteliais e queratinócitos. Seu ligante pode estar presente em monócitos, células NK, células $\mathrm{B}$, células $\mathrm{T}$, mastócitos e basófilos. Nossos dados demonstraram que, tanto FRCs quanto DNCs expressam constitutivamente CD40 em suas membranas. Adicionalmente, sua expressão gênica é aumentada em resposta ao IFN- $\gamma$, nas FRCs. Os estímulos inflamatórios, contudo, não induziram variação na expressão protéica nas populações celulares.

Similarmente, Nakayama e colaboradores (2015) mostraram que, embora as FRCs murinas expressem CD40 em condições basais, o nível dessa molécula não varia nas primeiras 24 horas em resposta ao estímulo alogênico in vivo. Do mesmo modo, Fletcher e colaboradores (2010) não observaram variação na expressão de CD40 quando o receptor TLR3 foi estimulado.

Estudos sugerem que as FRCs interagem com células T $\mathrm{CD}^{+}$através da ligação de CD40-CD40L, produzindo um efeito bidirecional. FRCs previamente estimuladas com anticorpo anti-CD40 favorecem a proliferação de células T. Por outro lado, a deficiência de CD40 em FRCs, quando co-cultivadas com células T CD4+ já ativadas, prejudicou consideravelmente a produção de quimiocinas e citocinas inflamatórias pelas FRCs. Tais informações sugerem que esta interação bidirecional entre FRCs e células T seja importante para a regulação da tolerância versus imunidade (Nakayama et al, 2015).

A proteína transmembrana CD83, membro da superfamília das imunoglobulinas, é conhecida como marcador de superfície em DCs maturas. Embora 
ainda não tenha sido demonstrado um papel importante de CD83 em DCs murinas, evidências sugerem que seja uma proteína com função reguladora da maturação de células T e linfócitos B (Breloer e Fleischer, 2008). Em nosso estudo, somente a expressão gênica de CD83 aumentou nas FRCs em resposta ao IFN- $\gamma$.

O receptor de morte celular programada -1 (do inglês Programmed cell death 1, PD-1) é um receptor induzível relacionado com a modulação da resposta imune, que pertence à família de receptores CD28. Interage com seus ligantes PD-L1 (B7.H1/CD274) e PD-L2 (B7.H2/CD273) participando na regulação negativa da resposta de células $\mathrm{T}$ à estimulação antigênica e na manutenção da tolerância periférica. PD-1 pode ser induzida em células $\mathrm{T}$ reguladoras, $\mathrm{T}$ foliculares, células $\mathrm{B}$ e células apresentadoras de antígenos como DCs e monócitos (Yao e Chen, 2014). Na literatura há divergência de dados em relação à expressão de PD-L1 em DNCs e FRCs em homeostase (Fletcher et al., 2010; Ng et al., 2012; Malhotra et al, 2012). Particularmente, nós detectamos PD-L1 nas DNCs e FRCs nessas condições. O estímulo com IFN- $\gamma$ induziu aumento de expressão de transcritos e proteína nas duas populações celulares. Em concordância com nossos resultados, $\mathrm{Ng}$ e colaboradores (2012) mostraram em FRCs murinas, aumento na expressão de PD-L1 em resposta ao IFN- $\gamma$ e IFN- $\beta$. Verificaram também que as FRCs interagem com as células $\mathrm{T}$, in vitro, através de MHC-I/II-TCR e PD-L1 na resposta antiviral, sugerindo que FRCs participam na iniciação da resposta de células $\mathrm{T}$ e teriam diferentes funções dependendo do estado de ativação dessas células. Similarmente, Fletcher e colaboradores (2010) observaram a expressão de PD-L1, tanto nas DNCs quanto FRCs em condições de repouso e um forte aumento na expressão após injeção de PolyI:C.

Além disso, observamos, sobretudo nas FRCs, superexpressão de transcritos que codificam as moléculas MHC-I e II, necessários para a apresentação de antígenos aos linfócitos $\mathrm{T} \mathrm{CD}^{+}$e $\mathrm{CD}^{+}$, respectivamente. Quando estimuladas com TNF- $\alpha+\mathrm{IL}-1 \beta$, DNCs e FRCs apresentaram maior expressão de mRNA para moléculas do MHC-I e proteínas envolvidas no processamento antigênico pela via do MHC-I: TAP1 e TAP2. A expressão gênica de TAP1/2 não foi observada em resposta ao IFN- $\gamma$.

Adicionalmente, em contraste com a resposta ao IFN- $\gamma$, o estímulo com TNF- $\alpha+$ IL-1 $\beta$ não favoreceu a expressão de genes que codificam moléculas do complexo MHCII. Porém, tanto DNCs quanto FRCs superexpressaram transcritos do gene CTSS que 
codifica a molécula catepsina $\mathrm{S}$, uma protease da família das cisteína protease, a qual apresenta função no processamento de antígenos pela via do MHC classe II.

Segundo os dados da literatura, as populações de células estromais dos LNs murinos, incluindo as DNCs e FRCs, expressam repertórios de antígenos próprios associados a tecidos periféricos, além disso, as FRCs murinas podem apresentar diretamente esses antígenos às células $\mathrm{T} \mathrm{CD}^{+}$, via $\mathrm{MHC}-\mathrm{I}$, induzindo tolerância (Fletcher et al, 2015). Todas as células nucleadas expressam constitutivamente a molécula MHC-I e as DNCs e FRCs não são exceção. Nós mostramos que ambas as populações expressam HLA-ABC na superfície celular em condições homeostáticas e tal expressão aumenta significativamente após estímulo com IFN- $\gamma$ ou TNF- $\alpha+$ IL- $1 \beta$, similar ao encontrado em outros estudos (Fletcher et al 2010; Ng et al, 2012; Malhotra et al, 2012). Esses dados sugerem a participação das DNCs e FRCs nos processos de apresentação de antígenos próprios a células $\mathrm{CD}^{+}$contribuindo para a manutenção da tolerância periférica.

Do mesmo modo, FRCs murinas podem interagir com as células T CD4+ mediante a expressão do MHC classe II, contribuindo também na indução de anergia nessas células (Cohen et al, 2010; Fletcher et al, 2010). Todavia, a expressão de MHCII é requerida para a manutanção de células T reguladoras (Baptista et al, 2014). Segundo a literatura, além de serem capazes de adquirir moléculas de MHC-II a partir das DCs, FRCs murinas possuem suas próprias moléculas. Adicionalmente, apenas FRCs murinas expressam baixos níveis de MHC-II na superfície em condições de homeostase (Malhotra et al, 2012; Baptista et al, 2014; Dubrot et al, 2014). Expressão de MHC-II é regulada pelo CIITA regulado a sua vez, nas FRCs, pelo promotor pIV, induzido por IFN- $\gamma$ (Dubrot et al, 2014). Similar ao estudo de Dubrot e colaboradores (2014) em células de camundongos, observamos em FRCs e DNCs, da espécie humana, aumento na expressão gênica e protéica do MHC-II em resposta ao estímulo com IFN- $\gamma$.

A literatura científica ainda é escassa em conhecimento sobre o perfil funcional de FRCs e DNCs dentro de LN em humanos. Nosso trabalho tem o intuito de contribuir para o entendimento das funções destas populações celulares, no contexto da resposta imune. Segundo nossos achados, DNCs e FRCs não exercem somente um papel estrutural nos LNs humanos. Observamos que estas células têm papel ativo dentro do órgão, tanto em condições de homeostase quanto em ambiente inflamatório. Em 
resposta aos estímulos inflamatórios IFN- $\gamma$ e TNF- $\alpha+$ IL-1 $\beta$, tanto DNCs quanto FRCs produzem moléculas que podem influenciar na ativação, mobilização e sobrevivência de vários subtipos celulares que participam da resposta imunológica, uma vez que sintetizam quimiocinas, citocinas, além de expressarem proteínas de superfície envolvidas tanto na indução quanto na regulação da resposta (Figuras 17 e 18).

Adicionalmente, foram demonstradas algumas diferenças entre as amostras, que proveem de pacientes com câncer, diverticulite e doadores de fígado. Obviamente mais estudos são necessários para melhor entender as diferenças existentes entre os grupos, uma vez que podem ser devido ao tipo de doença ou à localização desses linfonodos, ou seja, ao órgão do qual eles derivam. Do mesmo modo, outros estudos são requeridos para elucidar o papel das FRCs e DNCs na ativação ou supressão da resposta imune, bem como a cinética de expressão das moléculas responsáveis por estas funções.

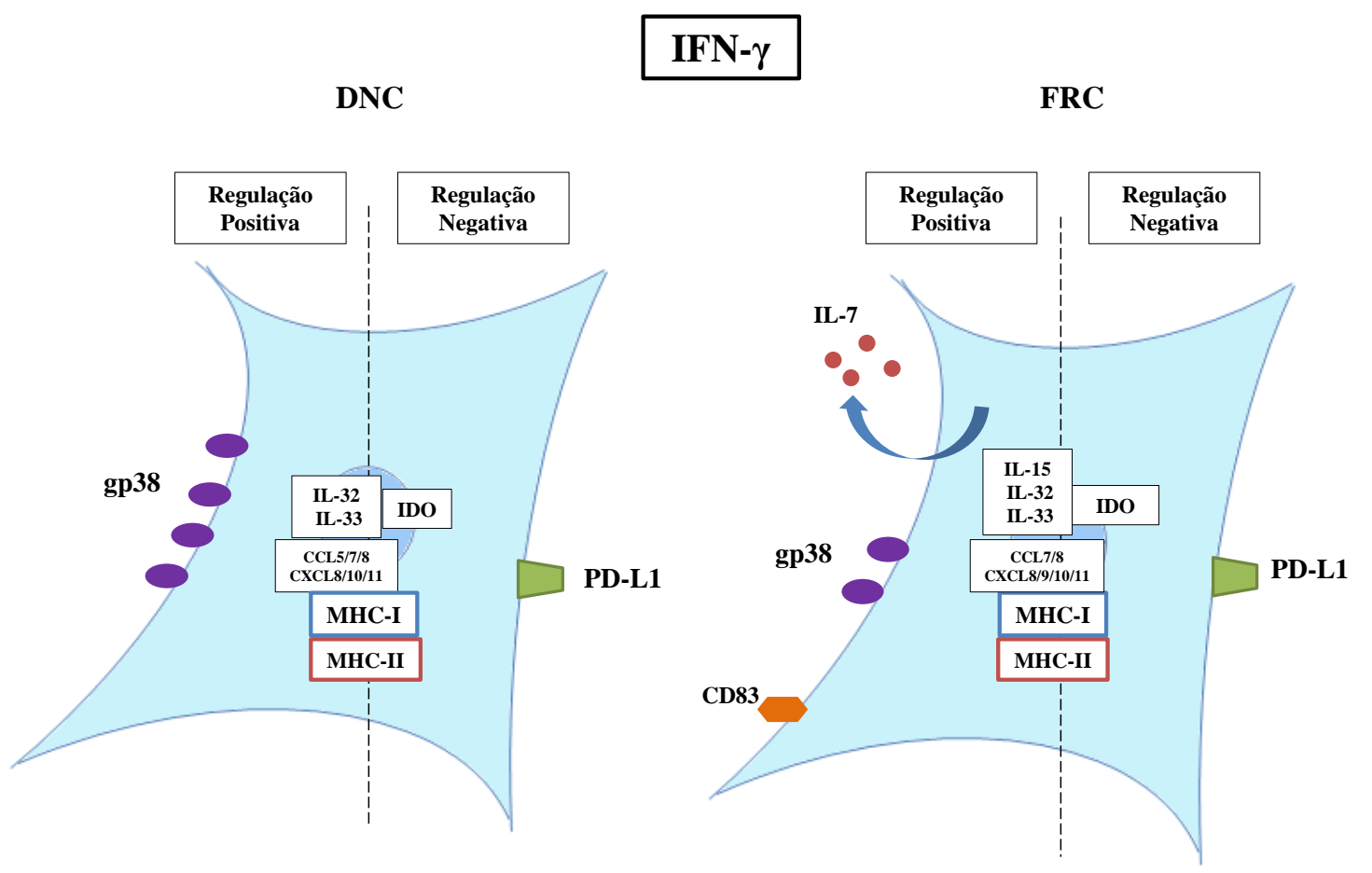

Figura 17. Perfil diferencial de superexpressão gênica e protéica de moléculas envolvidas na regulação positiva ou negativa da resposta imune após estímulo com IFN- $\gamma$, nas DNCs e FRCs. 


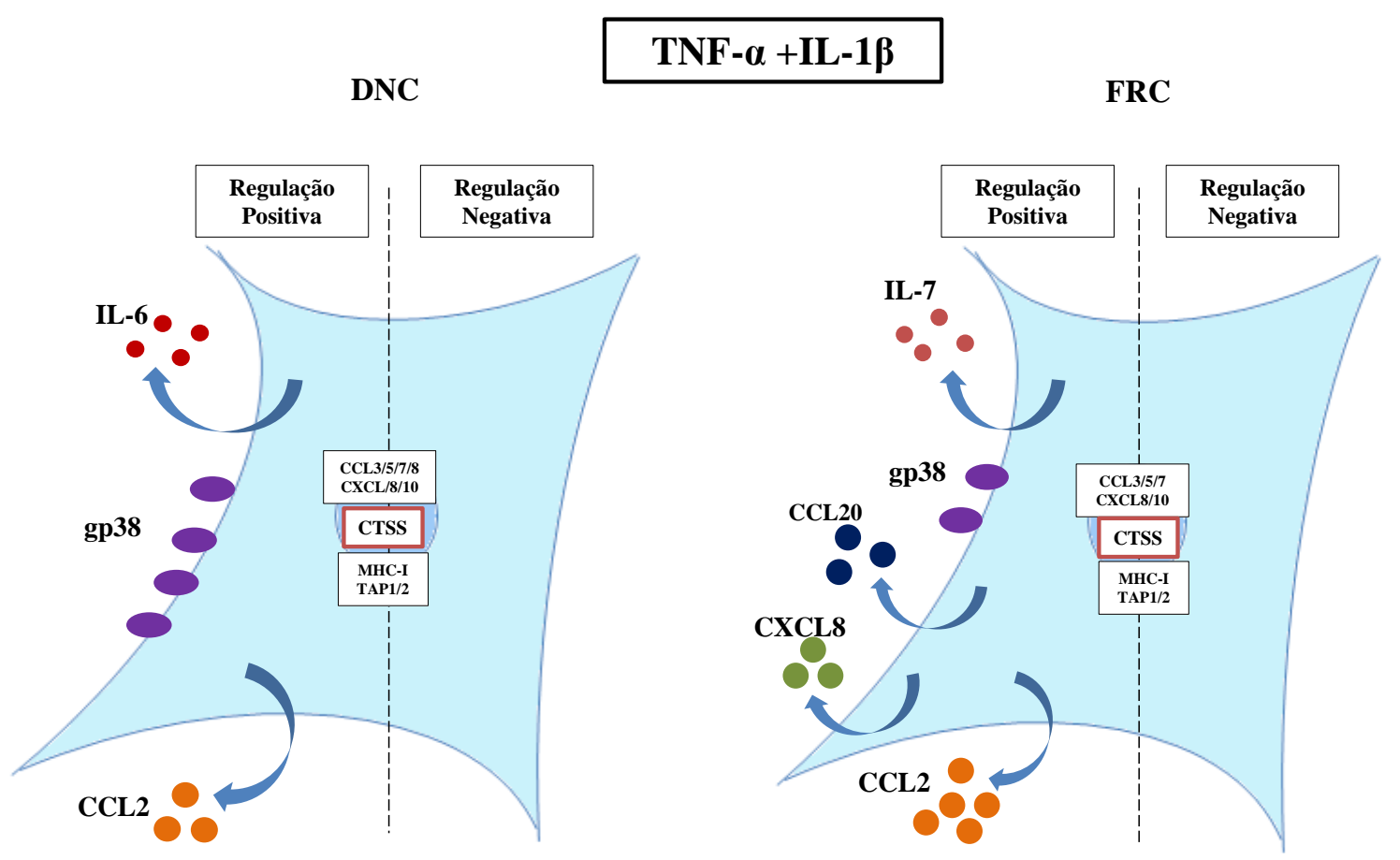

Figura 18. Perfil diferencial de superexpressão gênica e protéica de moléculas envolvidas na regulação positiva ou negativa da resposta imune após estímulo com TNF- $\alpha+$ IL-1ß, nas DNCs e FRCs.

\section{CONCLUSÃO}

Em conclusão, DNCs e FRCs apresentam diferenças no perfil de resposta segundo os estímulos inflamatórios aos quais estão expostas in vitro, aumentando a expressão de diferentes moléculas envolvidas na regulação positiva e negativa da resposta imune. 


\section{REFERÊNCIAS BIBLIOGRÁFICAS}

1. Acton SE, Astarita JL, Malhotra D, Lukacs-Kornek V, Franz B, Hess PR, Jakus Z, Kuligowski M, Fletcher AL, Elpek KG, Bellemare-Pelletier A, Sceats L, Reynoso ED, Gonzalez SF, Graham DB, Chang J, Peters A, Woodruff M, Kim YA, Swat W, Morita T, Kuchroo V, Carroll MC, Kahn ML, Wucherpfennig $\mathrm{KW}$, Turley SJ. Podoplanin rich stromal networks induce dendritic cell motility via activation of the C-type lectin receptor CLEC-2. Immunity. 2012 Aug 24;37(2):276-89.

2. Acton SE, Farrugia AJ, Astarita JL, Mourão-Sá D, Jenkins RP, Nye E, Hooper S, van Blijswijk J, Rogers NC, Snelgrove KJ, Rosewell I, Moita LF, Stamp G, Turley SJ, Sahai E, Reis e Sousa C.Dendritic cells control fibroblastic reticular network tension and lymph node expansion. Nature. 2014 Oct 23; 514(7523):498-502.

3. Alvarenga HG, Marti L. Multifunctional roles of reticular fibroblastic cells: more than meets the eye? J Immunol Res. 2014;2014:402038.

4. Anderson MS, Venanzi ES, Klein L, Chen Z, Berzins SP, Turley SJ, von Boehmer H, Bronson R, Dierich A, Benoist C, Mathis D.Projection of an immunological self shadow within the thymus by the aire protein.Science. 2002 Nov 15;298(5597):1395-401.

5. Annunziato F, Santarlasci V, Maggi L, Cosmi L, Liotta F, Romagnani S. Reasons for rarity of Th17 cells in inflammatory sites of human disorders. 2013 Nov 15;25(4):299-304.

6. Astarita JL, Acton SE, Turley SJ. Podoplanin: emerging functions in development, the immune system, and cancer. Front Immunol. 2012 Sep $12 ; 3: 283$.

7. Astarita JL, Cremasco V, Fu J, Darnell MC, Peck JR, Nieves-Bonilla JM, Song K, Kondo Y, Woodruff MC, Gogineni A, Onder L, Ludewig B, Weimer RM, Carroll MC, Mooney DJ, Xia L, Turley SJ.The CLEC-2-podoplanin axis controls the contractility of fibroblastic reticular cells and lymph node microarchitecture.Nat Immunol. 2015 Jan;16(1):75-84. 
8. Bajénoff M, Egen JG, Koo LY, Laugier JP, Brau F, Glaichenhaus N, Germain RN.Stromal cell networks regulate lymphocyte entry, migration, and territoriality in lymph nodes.Immunity 2006 Dec;25(6):989-1001.

9. Roozendaal R, Reijmers RM, Koning JJ, Unger WW, Greuter M, Keuning ED, Molenaar R, Goverse G, Sneeboer MM, den Haan JM, Boes M, Mebius RE. Lymph node stromal cells constrain immunity via MHC class II self-antigen presentation. Elife. 2014 Nov 19;3.

10. Bénézech C, Mader E, Desanti G, Khan M, Nakamura K, White A, Ware CF, Anderson G, Caamaño JH.Lymphotoxin- $\beta$ receptor signaling through NF- $\mathrm{BB} 2-$ RelB pathway reprograms adipocyte precursors as lymph node stromal cells.Immunity. 2012 Oct 19;37(4):721-34.

11. Bertozzi CC, Schmaier AA, Mericko P, Hess PR, Zou Z, Chen M, Chen CY, Xu B, Lu MM, Zhou D, Sebzda E, Santore MT, Merianos DJ, Stadtfeld M, Flake AW, Graf T, Skoda R, Maltzman JS, Koretzky GA, Kahn ML.Platelets regulate lymphatic vascular development through CLEC-2-SLP-76 signaling.Blood. 2010 Jul 29;116(4):661-70.

12. Bingisser RM, Tilbrook PA, Holt PG, Kees UR.Macrophage-derived nitric oxide regulates $\mathrm{T}$ cell activation via reversible disruption of the Jak3/STAT5 signaling pathway.J Immunol. 1998 Jun 15;160(12):5729-34.

13. Breloer, Fleischer. CD83 regulates lymphocyte maturation, activation and homeostasis. Trends Immunol. 2008 Apr;29(4):186-94

14. Brendolan A, Caamaño JH.Mesenchymal cell differentiation during lymph node organogenesis.Front Immunol. 2012 Dec 14;3:381.

15. Bromley SK, Mempel TR, Luster AD.Orchestrating the orchestrators: chemokines in control of T cell traffic.Nat Immunol. 2008 Sep;9(9):970-80.

16. Chai Q, Onder L, Scandella E, Gil-Cruz C, Perez-Shibayama C, Cupovic J, Danuser R, Sparwasser T, Luther SA, Thiel V, Rülicke T, Stein JV, Hehlgans T, Ludewig B. Maturation of lymph node fibroblastic reticular cells from myofibroblastic precursors is critical for antiviral immunity. Immunity. 2013 May 23;38(5):1013-24.

17. Chang JE, Turley SJ.Stromal infrastructure of the lymph node and coordination of immunity.Trends Immunol. 2015 Jan;36(1):30-9. 
18. Chappaz S, Finke D. The IL-7 signaling pathwayregulates lymph node development independentof peripheral lymphocytes. J Immunol. 2010;184(7):3562-3569.

19. Charo IF, Ransohoff RM.The many roles of chemokines and chemokine receptors in inflammation.N Engl J Med. 2006 Feb 9;354(6):610-21.

20. Chyou S, Ekland EH, Carpenter AC, Tzeng TC, Tian S, Michaud M, Madri JA, Lu TT. Fibroblast-type reticular stromal cells regulate the lymph node vasculature. J Immunol. 2008 Sep 15;181(6):3887-96.

21. Chyou S, Benahmed F, Chen J, Kumar V, Tian S, Lipp M, Lu TT.Coordinated regulation of lymph node vascular-stromal growth first by CD11c+ cells and then by T and B cells.J Immunol. 2011 Dec 1;187(11):5558-67.

22. Clark SL Jr. The reticulum of lymph nodes in mice studied with the electron microscope. Am J Anat. 1962 May;110:217-57. PubMed PMID: 13879732.

23. Cohen JN, Guidi CJ, Tewalt EF, Qiao H, Rouhani SJ, Ruddell A, Farr AG, Tung KS, Engelhard VH.Lymph node-resident lymphatic endothelial cells mediate peripheral tolerance via Aire-independent direct antigen presentation. J Exp Med 2010 Apr 12;207(4):681-8.

24. Couper KN, Blount DG, Riley EM. IL-10: the master regulator of immunity to infection. J Immunol. 2008 May 1;180(9):5771-7. Review.

25. Crivellato, E., \& Mallardi, F. Stromal cell organisation in the mouse lymph node. A light and electron microscopic investigation using the zinc iodideosmium technique. Journal of anatomy.1997; 190, 85-92.

26. Cremasco V, Woodruff MC, Onder L, Cupovic J, Nieves-Bonilla JM, Schildberg FA, Chang J, Cremasco F, Harvey CJ, Wucherpfennig K, Ludewig B, Carroll MC, Turley SJ.B cell homeostasis and follicle confines are governed by fibroblastic reticular cells. Nat Immunol 2014 Oct;15(10):973-81.

27. Cupedo T, Stroock A, Coles M.Application of tissue engineering to the immune system: development of artificial lymph nodes.Front Immunol. 2012 Nov $16 ; 3: 343$

28. Cyster JG, Ansel KM, Reif K, Ekland EH, Hyman PL, Tang HL, Luther SA, Ngo VN.Follicular stromal cells and lymphocyte homing to follicles. Immunol Rev. 2000 Aug;176:181-93. 
29. Cyster JG, Schwab SR.Sphingosine-1-phosphate and lymphocyte egress from lymphoid organs.Annu Rev Immunol. 2012;30:69-94.

J.G. Cyster, Blown away: the unexpected role of lymphotoxin in lymphoid organ development, J. Immunol. 192 (2014) 2007-2009.

30. De Togni P, Goellner J, Ruddle NH, Streeter PR, Andrea F, Mariathasan S, Smith SC, Carlson R, Shornick LP, Strauss-Schoenberger J, Russell JH, Karr R, Chaplin DD.Pillars article: Abnormal development of peripheral lymphoid organs in mice deficient in lymphotoxin. Science.J Immunol. 2014 Mar 1;192(5):2010-4.

31. Dinarello CA, Novick D, Kim S, Kaplanski G.Interleukin-18 and IL-18 binding protein. Front Immunol. 2013 Oct 8;4:289.

32. Dorman and Holland. Interferon-gamma and interleukin-12 pathway defects and human disease. Cytokine Growth Factor Rev. 2000 Dec;11(4):321-33.

33. Dubrot J, Duraes FV, Potin L, Capotosti F, Brighouse D, Suter T, LeibundGutLandmann S, Garbi N, Reith W, Swartz MA, Hugues S.Lymph node stromal cells acquire peptide-MHCII complexes from dendritic cells and induce antigenspecific CD4 ${ }^{+}$T cell tolerance.J Exp Med. 2014 Jun 2;211(6):1153-66.

34. Fletcher AL, Lukacs-Kornek V, Reynoso ED, Pinner SE, Bellemare-Pelletier A, Curry MS, Collier AR, Boyd RL, Turley SJ.Lymph node fibroblastic reticular cells directly present peripheral tissue antigen under steady-state and inflammatory conditions. J Exp Med 2010 Apr 12;207(4):689-97.

35. Fletcher AL, Malhotra D, Acton SE, Lukacs-Kornek V, Bellemare-Pelletier A, Curry M, Armant M, Turley SJ. Reproducible isolation of lymph node stromal cells reveals site-dependent differences in fibroblastic reticular cells. Front Immunol. 2011;2:35(a).

36. Fletcher AL, Malhotra D, Turley SJ. Lymph node stroma broaden the peripheral tolerance paradigm. Trends Immunol. $2011 \mathrm{Jan} ; 32(1): 12-8(\mathrm{~b})$.

37. Fletcher AL, Acton SE, Knoblich K.Lymph node fibroblastic reticular cells in health and disease. Nat Rev Immunol. 2015 May 22.

38. Francisco LM, Salinas VH, Brown KE, Vanguri VK, Freeman GJ, Kuchroo VK, Sharpe AH.PD-L1 regulates the development, maintenance, and function of induced regulatory T cells.J Exp Med 2009 Dec 21;206(13):3015-29. 
39. Reinhold Förster, Ana Clara Davalos-Misslitz and Antal Rot. CCR7 and its ligands: balancing immunity and tolerance. Nat Rev Immunol. 2008 May;8(5):362-71.

40. Gardner JM, Devoss JJ, Friedman RS, Wong DJ, Tan YX, Zhou X, Johannes KP, Su MA, Chang HY, Krumme MF, Anderson MS.Deletional tolerance mediated by extrathymic Aire-expressing cells.Science 2008 Aug 8;321(5890):843-7.

41. Gharibi T, Majidi J, Kazemi T, Dehghanzadeh R, Motallebnezhad M, Babaloo Z.Biological effects of IL-21 on different immune cells and its role in autoimmune diseases.Immunobiology. 2016 Feb;221(2):357-67.

42. Griffith JW, Sokol CL, Luster AD. Chemokines and chemokine receptors: positioning cells for host defense and immunity. Annu Rev Immunol. 2014;32:659-702.

43. Grigorova IL, Schwab SR, Phan TG, Pham TH, Okada T, Cyster JG.Cortical sinus probing, S1P1-dependent entry and flow-based capture of egressing $\mathrm{T}$ cells.Nat Immunol. $2009 \mathrm{Jan} ; 10(1): 58-65$.

44. Gualde N, Harizi H.Prostanoids and their receptors that modulate dendritic cellmediated immunity.Immunol Cell Biol. 2004 Aug;82(4):353-60.

45. Hess E, Duheron V, Decossas M, Lézot F, Berdal A, Chea S, Golub R, Bosisio MR, Bridal SL, Choi Y, Yagita H, Mueller CG. RANKL induces organized lymph node growth by stromal cell proliferation. J Immunol. 2012 Feb $1 ; 188(3): 1245-54$.

46. Hossein and Akbar. CD40 and Tolerance Induction Iran J Allergy Asthma Immunol March 2012; 11(1): 1-13. Review

47. Jimenez F, Quinones MP, Martinez HG, Estrada CA, Clark K, Garavito E, Ibarra J, Melby PC, Ahuja SS. CCR2 plays a critical role in dendritic cell maturation: possible role of CCL2 and NF-kappa B. J Immunol. 2010 May 15;184(10):5571-81.

48. Kalamajski S, Oldberg A.The role of small leucine-rich proteoglycans in collagen fibrillogenesis.Matrix Biol. 2010 May;29(4):248-53.

49. Kang J, Coles M.IL-7: the global builder of the innate lymphoid network and beyond, one niche at a time.Semin Immunol. 2012 Jun;24(3):190-7. 
50. Kasic T, Colombo P, Soldani C, Wang CM, Miranda E, Roncalli M, Bronte V, Viola A. Modulation of human T-cell functions by reactive nitrogen species.Eur J Immunol. 2011 Jul;41(7):1843-9.

51. Katakai T, Hara T, Sugai M, Gonda H, Shimizu A. Lymph node fibroblastic reticular cells construct the stromal reticulum via contact with lymphocytes. J Exp Med. 2004 Sep 20;200(6):783-95.

52. Katakai T, Suto H, Sugai M, Gonda H, Togawa A, Suematsu S, Ebisuno Y, Katagiri K, Kinashi T, Shimizu A.Organizer-like reticular stromal cell layer common to adult secondary lymphoid organs.J Immunol. 2008 Nov 1;181(9):6189-200.

53. Katakai T.Marginal reticular cells: a stromal subset directly descended from the lymphoid tissue organizer. Front Immunol. 2012 Jul 12;3:200.

54. Kerjaschki D, Regele HM, Moosberger I, Nagy-Bojarski K, Watschinger B, Soleiman A, Birner P, Krieger S, Hovorka A, Silberhumer G, Laakkonen P, Petrova T, Langer B, Raab I.Lymphatic neoangiogenesis in human kidney transplants is associated with immunologically active lymphocytic infiltrates. J Am Soc Nephrol. 2004 Mar;15(3):603-12.

55. Kerrigan AM, Dennehy KM, Mourão-Sá D, Faro-Trindade I, Willment JA, Taylor PR, Eble JA, Reis e Sousa C, Brown GD.CLEC-2 is a phagocytic activation receptor expressed on murine peripheral blood neutrophils.J Immunol. 2009 Apr 1;182(7):4150-7.

56. Khan O, Headley M, Gerard A, Wei W, Liu L, Krummel MF. Regulation of T cell priming by lymphoid stroma. PLoS One. 2011;6(11):e26138.

57. Koni PA, Sacca R, Lawton P, Browning JL, Ruddle NH, Flavell RA.Distinct roles in lymphoid organogenesis for lymphotoxins alpha and beta revealed in lymphotoxin beta-deficient mice. Immunity 1997 Apr;6(4):491-500.

58. Kong YY, Yoshida H, Sarosi I, Tan HL, Timms E, Capparelli C, Morony S, Oliveira-dos-Santos AJ, Van G, Itie A, Khoo W, Wakeham A, Dunstan CR, Lacey DL, Mak TW, Boyle WJ, Penninger JM.OPGL is a key regulator of osteoclastogenesis, lymphocyte development and lymph-node organogenesis. Nature 1999 Jan 28;397(6717):315-23.

59. Kuby, Janis; Kindt, Thomas J.; Goldsby, Richard A.; Osborne, Barbara A. (2007). Kuby immunology. San Francisco: W.H. Freeman. ISBN 1-4292-0211-4 
60. Le Blanc K, Mougiakakos D.Multipotent mesenchymal stromal cells and the innate immune system.Nat Rev Immunol. 2012 Apr 25;12(5):383-96.

61. Lee JW, Epardaud M, Sun J, Becker JE, Cheng AC, Yonekura AR, Heath JK, Turley SJ.Peripheral antigen display by lymph node stroma promotes $\mathrm{T}$ cell tolerance to intestinal self.Nat Immunol 2007 Feb;8(2):181-90.

62. Lee YJ, Won TJ, Hyung KE, Jang YW, Kim SJ, Lee DI, Park SY, Hwang KW. IL6 induced proliferation and cytotoxic activity of CD8+ T cells is elevated by S UMO2 overexpression. Arch Pharm Res. 2016 Apr 12.

63. Link A, Vogt TK, Favre S, Britschgi MR, Acha-Orbea H, Hinz B, Cyster JG,Luther SA. Fibroblastic reticular cells in lymph nodes regulate the homeostasis of naive T cells. Nat Immunol. 2007 Nov;8(11):1255-65.

64. Link A, Hardie DL, Favre S, Britschgi MR, Adams DH, Sixt M, Cyster JG, Buckley CD, Luther SA. Association of T-zone reticular networks and conduits with ectopic lymphoid tissues in mice and humans. Am J Pathol. 2011 Apr;178(4):1662-75.

65. Leandro MJ. B-cell subpopulations in humans and their differential susceptibility to depletion with anti-CD20 monoclonal antibodies. Arthritis Res Ther. 2013;15(Suppl 1):S3. Lukacs-Kornek V, Malhotra D, Fletcher AL, Acton SE, Elpek KG, Tayalia P, Collier AR, Turley SJ. Regulated release of nitric oxide by nonhematopoietic stroma controls expansion of the activated $\mathrm{T}$ cell pool in lymph nodes. Nat Immunol. 2011 Sep 18;12(11):1096-104.

66. Luther SA, Lopez T, Bai W, Hanahan D, Cyster JG.BLC expression in pancreatic islets causes B cell recruitment and lymphotoxin-dependent lymphoid neogenesis. Immunity 2000 May;12(5):471-81.

67. Luther SA, Vogt TK, Siegert S. Guiding blind T cells and dendritic cells: A closer look at fibroblastic reticular cells found within lymph node $\mathrm{T}$ zones. Immunol Lett. 2011 Jul;138(1):9-11.

68. Mackall CL, Fry TJ, Gress RE. Harnessing thebiology of IL-7 for therapeutic application.Nat Rev Immunol. 2011;11(5):330-342.

69. Magnusson FC1, Liblau RS, von Boehmer H, Pittet MJ, Lee JW, Turley SJ, Khazaie K.Direct presentation of antigen by lymph node stromal cells protects against CD8 T-cell-mediated intestinal autoimmunity.Gastroenterology 2008 Apr;134(4):1028-37. 
70. Malhotra D, Fletcher AL, Astarita J, Lukacs-Kornek V, Tayalia P, Gonzalez SF, Elpek KG, Chang SK, Knoblich K, Hemler ME, Brenner MB, Carroll MC, Mooney DJ, Turley SJ; Immunological Genome Project Consortium. Transcriptional profiling of stroma from inflamed and resting lymph nodes defines immunological hallmarks. Nat Immunol. 2012 Apr 1;13(5):499-510.

71. Malhotra, D., A. L. Fletcher, and S. J. Turley. Stromal and hematopoietic cells in secondary lymphoid organs: partners in immunity. Immunol. Rev 2013 Jan;251(1):160-76.

72. Masopust D, Schenkel JM.. The integration of T cell migration, differentiation and function. Nat Rev Immunol. 2013 May;13(5):309-20.

73. Mempel TR, Henrickson SE, Von Andrian UH.T-cell priming by dendritic cells in lymph nodes occurs in three distinct phases.Nature 2004 Jan 8;427(6970):154-9.

74. Mishra A, Sullivan L, Caligiuri MA. Molecular pathways: interleukin-15 signaling in health and in cancer. Clin Cancer Res. 2014 Apr 15;20(8):2044-50.

75. Miyasaka, M. \& Tanaka, T. Lymphocyte trafficking across high endothelial venules: dogmas and enigmas. Nat Rev Immunol 2004 May;4(5):360-70.

76. Moser B, Loetscher P.Moser B1, Loetscher P.Nat Immunol 2001 Feb;2(2):1238.

77. Mueller SN, Ahmed R. Lymphoid stroma in the initiation and control of immune responses. Immunol Rev. 2008 Aug; 224:284-94.

78. Mueller SN, Germain RN. Stromal cell contributions to the homeostasis and functionality of the immune system. Nat Rev Immunol. 2009 Sep;9(9):618-29.

79. Mueller SN, Gebhardt T, Carbone FR, Heath WR.Memory T cell subsets, migration patterns, and tissue residence.Annu Rev Immunol. 2013;31:137-61.

80. NakayamaY, BrinkmanCC, BrombergJS.

Murine Fibroblastic Reticular Cells from Lymph Node Interact With CD4+ T Ce lls Through CD40-CD40L. Transplantation. 2015 Aug; 99(8):1561-7.

81. Navarro-Núñez L, Langan SA, Nash GB, Watson SP. The physiological and pathophysiological roles of platelet CLEC-2. Thromb Haemost. 2013 Jun;109(6):991-8. 
82. Ng CT, Nayak BP, Schmedt C, Oldstone MB.Immortalized clones of fibroblastic reticular cells activate virus-specific $\mathrm{T}$ cells during virus infection.Proc Natl Acad Sci U S A. 2012 May 15;109(20):7823-8.

83. Nichols LA1, Chen Y, Colella TA, Bennett CL, Clausen BE, Engelhard VH.Nichols LA1, Chen Y, Colella TA, Bennett CL, Clausen BE, Engelhard VH. J Immunol. 2007 Jul 15;179(2):993-1003.

84. Okada T, Ngo VN, Ekland EH, Förster R, Lipp M, Littman DR, Cyster JG. Chemokine requirements for B cell entry to lymph nodes and Peyer's patches.J Exp Med. 2002 Jul 1;196(1):65-75.

85. Onder L, Narang P, Scandella E, Chai Q, Iolyeva M, Hoorweg K, Halin C, Richie E, Kaye P, Westermann J, Cupedo T, Coles M, Ludewig B. IL-7producing stromal cells are critical for lymph node remodeling. Blood. 2012 Dec 6;120(24):4675-83.

86. Ramsey C, Winqvist O, Puhakka L, Halonen M, Moro A, Kämpe O, Eskelin P, Pelto-Huikko M, Peltonen L.Aire deficient mice develop multiple features of APECED phenotype and show altered immune response.Hum Mol Genet. 2002 Feb 15;11(4):397-409.

87. Rodriguez PC, Zea AH, Culotta KS, Zabaleta J, Ochoa JB, Ochoa AC.Regulation of $\mathrm{T}$ cell receptor $\mathrm{CD} 3 z$ zeta chain expression by $\mathrm{L}$-arginine.J Biol Chem. 2002 Jun 14;277(24):21123-9.

88. Roozendaal R, Mebius RE.Stromal cell-immune cell interactions.Annu Rev Immunol. 2011;29:23-43.

89. The role of IL-33 and mast cells in allergy and inflammation. Saluja R, Khan M, Church MK, Maurer M.Clin Transl Allergy. 2015 Sep 29;5:33.

90. Saperstein S, Chen L, Oakes D, Pryhuber G, Finkelstein J. IL-1beta augments TNF-alpha-mediated inflammatory responses from lung epithelial cells. J Interferon Cytokine Res. 2009 May;29(5):273-84.

91. Shamri R, Grabovsky V, Gauguet JM, Feigelson S, Manevich E, Kolanus W, Robinson MK, Staunton DE, von Andrian UH, Alon R.Lymphocyte arrest requires instantaneous induction of an extended LFA-1 conformation mediated by endothelium-bound chemokines.Nat Immunol. 2005 May;6(5):497-506.

92. Siegert S, Huang HY, Yang CY, Scarpellino L, Carrie L, Essex S, Nelson PJ, Heikenwalder M, Acha-Orbea H, Buckley CD, Marsland BJ, Zehn D, Luther 
SA. Fibroblastic reticular cells from lymph nodes attenuate $\mathrm{T}$ cell expansion by producing nitric oxide. PLoS One. 2011;6(11):e27618.

93. Siegert S, Luther SA. Positive and negative regulation of $\mathrm{T}$ cell responses by fibroblastic reticular cells within paracortical regions of lymph nodes. Front Immunol. 2012 Sep 11;3:285.

94. Sixt M, Kanazawa N, Selg M, Samson T, Roos G, Reinhardt DP, Pabst R, Lutz MB, Sorokin L.The conduit system transports soluble antigens from the afferent lymph to resident dendritic cells in the T cell area of the lymph node.Immunity. 2005 Jan;22(1):19-29.

95. Steele KE, Anderson AO, Mohamadzadeh M. Fibroblastic reticular cell infection by hemorrhagic fever viruses. Immunotherapy. 2009 Mar;1(2):187-97.

96. Soderberg KA, Payne GW, Sato A, Medzhitov R, Segal SS, Iwasaki A.Innate control of adaptive immunity via remodeling of lymph node feed arteriole.Proc Natl Acad Sci U S A. 2005 Nov 8;102(45):16315-20.

97. Surh CD, Sprent J.Homeostasis of naive and memory T cells.Immunity. 2008 Dec 19;29(6):848-62.

98. Suzuki-Inoue K, Fuller GL, García A, Eble JA, Pöhlmann S, Inoue O, Gartner TK, Hughan SC, Pearce AC, Laing GD, Theakston RD, Schweighoffer E, Zitzmann N, Morita T, Tybulewicz VL, Ozaki Y, Watson SP.A novel Sykdependent mechanism of platelet activation by the C-type lectin receptor CLEC2.Blood 2006 Jan 15;107(2):542-9.

99. Suzuki-Inoue K, Inoue O, Ozaki Y. The novel platelet activation receptor CLEC-2. Platelets. 2011;22(5):380-4.

100. Tan KW, Yeo KP, Wong FH, Lim HY, Khoo KL, Abastado JP, Angeli V.Expansion of cortical and medullary sinuses restrains lymph node hypertrophy during prolonged inflammation.J Immunol. 2012 Apr 15;188(8):4065-80.

101. Thomazy VA, Vega F, Medeiros LJ, Davies PJ, Jones D. Phenotypic modulation of the stromal reticular network in normal and neoplastic lymph nodes: tissue transglutaminase reveals coordinate regulation of multiple cell types. Am Pathol. 2003 Jul;163(1):165-74.

102. Trefzer U, Hofmann M, Reinke S, Guo YJ, Audring H, Spagnoli G, Sterry W.Concordant loss of melanoma differentiation antigens in synchronous 
and asynchronous melanoma metastases: implications for immunotherapy.Melanoma Res. 2006 Apr;16(2):137-45.

103. Turley SJ, Fletcher AL, Elpek KG. The stromal and haematopoietic antigen-presenting cells that reside in secondary lymphoid organs. Nat Rev Immunol. 2010 Dec;10(12):813-25.

104. Van de Pavert SA, Olivier BJ, Goverse G, Vondenhoff MF, Greuter M, Beke P, Kusser K, Höpken UE, Lipp M, Niederreither K, Blomhoff R, Sitnik K, Agace WW, Randall TD, de Jonge WJ, Mebius RE.Chemokine CXCL13 is essential for lymph node initiation and is induced by retinoic acid and neuronal stimulation.Nat Immunol. 2009 Nov;10(11):1193-9.

105. Vega F, Coombes KR, Thomazy VA, Patel K, Lang W, Jones D.Tissuespecific function of lymph node fibroblastic reticulum cells.Pathobiology. 2006;73(2):71-81.

106. Von Andrian UH, Mempel TR.Homing and cellular traffic in lymph nodes.Nat Rev Immunol 2003 Nov;3(11):867-78.

107. Watson SP, Herbert JM, Pollitt AY.GPVI and CLEC-2 in hemostasis and vascular integrity.J Thromb Haemost. $2010 \mathrm{Jul} ; 8(7): 1456-67$.

108. Webster B, Ekland EH, Agle LM, Chyou S, Ruggieri R, Lu TT. Regulation of lymph node vascular growth by dendritic cells. J Exp Med. 2006 Aug 7;203(8):1903-13.

109. Willard-Mack CL.Normal structure, function, and histology of lymph nodes.Toxicol Pathol. 2006;34(5):409-24.

110. Yang CY, Vogt TK, Favre S, Scarpellino L, Huang HY, Tacchini-Cottier F, Luther SA.Trapping of naive lymphocytes triggers rapid growth and remodeling of the fibroblast network in reactive murine lymph nodes.Proc Natl Acad Sci U S A. 2013 Jan 7;111(1):E109-18.

111. Yao, Chen. PD-1 as an Immune Modulatory Receptor. Cancer J. 2014 ; 20(4): 262-264.Review.

112. Yip L, Su L, Sheng D, Chang P, Atkinson M, Czesak M, Albert P R, Collier A, Turley S J, Fathman C G, Creusot R J. Deaf1 isoforms control the expression of genes encoding peripheral tissue antigens in the pancreatic lymph nodes during type 1 diabetes. Nat Rev Immunol. 2009 Set; 10(9): 1026-1033. 
113. Zhao,Xia ,Wang, Xu. Transcriptional regulation of CCL20 expression. Microbes Infect. 2014 Oct;16(10):864-70.

114. Zhao L, Chen J, Liu L, Gao J, Guo B, Zhu B.Essential role of TNF-alpha in development of spleen fibroblastic reticular cells.Cell Immunol. 2015 Feb;293(2):130-6.

115. Zhou Y, Zhu Y. Important Role of the IL-32 Inflammatory Network in the Host Response against Viral Infection. Viruses. 2015 Jun 16;7(6):3116-29.

116. Zhu M, Fu YX.The role of core TNF/LIGHT family members in lymph node homeostasis and remodeling.Immunol Rev 2011 Nov;244(1):75-84.

117. Zlotnik A, Burkhardt AM, Homey B.Homeostatic chemokine receptors and organ-specific metastasis.Nat Rev Immunol. 2011 Aug 25;11(9):597-606. 


\section{APÊNDICES}

\section{ALBERT EINSTEIN}

ENisino $t$ intsouis

\section{HOSPITAL ISRAELITA ALBERT EINSTEIN-SP \\ Q Pratoforma}

\section{PARECER CONSUBSTANCIADO DO CEP}

\section{DADOS DO PROJETO DE PESQUISA}

Título da Pesquisa: Identificar e isolar células-tronco estromais de linfonodos humanos.

Pesquisador: Luciana Cavalheiro Marti

Área Temática:

Versão: 5

CAAE: 07768712.4 .0000 .0071

Instituição Proponente: Hospital Israelita Albert Einstein-SP

Patrocinador Principal: Hospital Israelita Albert Einstein-SP

\section{DADOS DO PARECER}

Número do Parecer: 721.550

Data da Relatoria: 08/07/2014

Apresentação do Projeto:

Os linfonodos são cerca de 400 pequenos órgãos distribuídos pelo corpo e que tem papel importante na tolerância e resposta imunológica. Dentre a

variedade de células que compõe a estrutura deste pequeno órgãos as células estromais embora pouco estudadas parece ter papel importante na

modulação das respostas imunes e na tolerância periférica. Em contrapartida as células estromais derivadas de medula óssea tem seu papel na

imunomodulação e vem sendo utilizada em ensaio clínico de doença do enxerto vs hospedeiro. Nossa hipótese é que as células mesenquimais

derivadas de medula óssea tenham papel cognato as ELs quando em presença de uma resposta inflamatória já em curso, interferindo na modulação

destas respostas, como também na sobrevivência e tráfego de diferentes células do sistema imune.O aumento do conhecimento da biologia e da

função de células do estroma presentes nos linfonodos pode proporcionar vias de valor terapêutico o tratamento de doenças como a $\mathrm{DECH}$,

doenças auto-imunes e infecções.

Objetivo da Pesquisa:

Isolar e caracterizar as ELs de linfonodos humanos, mais precisamente células reticulares

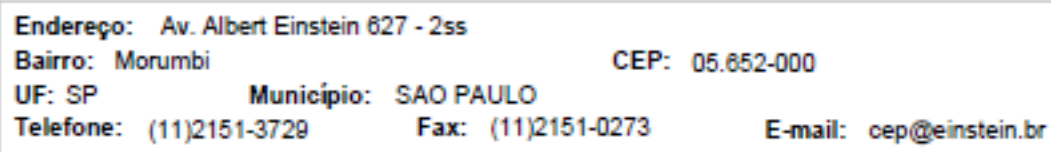


Contnuaçăo do Parecer. 721.550

fibroblásticas (FRC), comparar as características

encontradas nestas ELs com as características das MSCs humanas derivadas de medula óssea.

Avaliação dos Riscos e Benefícios:

Não há riscos para o doador uma vez que os linfonodos de cadáver são removidos descartados antes do transplante do órgão. O risco da remoção

de linfonodo para realização do exame anatomopatológico não será alterado pela doação de parte do linfonodo enviado ao exame.Não há benefícios para o doador. Apenas a contribuição cientifica que poderá gerar novo conhecimento nesta área.

Comentários e Considerações sobre a Pesquisa:

Trata-se de um projeto de pesquisa já aprovado pelo CEP HIAE. O pesquisador entrou com uma emenda ao CEP solicitando a inclusão de amostra de sangue de paciente coletada pelo laboratório clínico que esteja excedente no projeto de pesquisa devido ao fato de que as amostras de linfonodos isoladas dos linfonodos apresentarem características diferentes das células isoladas de sangue periférico. Para isso o TCLE foi modificado de acordo com o solicitado.

Consideraçôes sobre os Termos de apresentação obrigatória:

De acordo.

Recomendações:

Aprovado

Conclusões ou Pendências e Lista de Inadequações:

Aprovado o seguinte documento:

1-Termo 2 (Linfonodo-biopsia) - Versão 3 datada de 16 de Junho de 2014.

Situação do Parecer:

Aprovado

Necessita Apreciação da CONEP:

Não

Considerações Finais a critério do CEP:

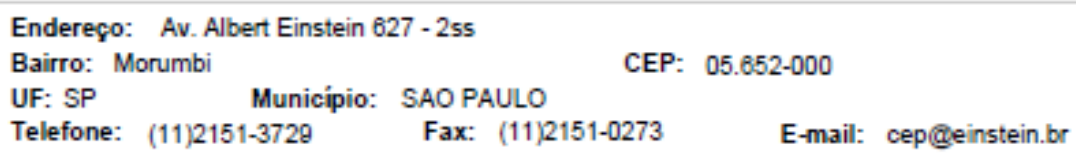



EINSTEIN-SP

Contnuaçăo do Parecer. 721.550

SAO PAULO, 17 de Julho de 2014

Assinado por:

Fabio Pires de Souza Santos

(Coordenador) 


\title{
Chemokines and immunity
}

\author{
Quimiocinas e imunidade
}

\author{
Diana Carolina Torres Palomino ${ }^{1,2}$, Luciana Cavalheiro Marti ${ }^{1,2}$
}

\begin{abstract}
Chemokines are a large family of small cytokines and generally have low molecular weight ranging from 7 to $15 \mathrm{kDa}$. Chemokines and their receptors are able to control the migration and residence of all immune cells. Some chemokines are considered pro-inflammatory, and their release can be induced during an immune response at a site of infection, while others are considered homeostatic and are involved in controlling of cells migration during tissue development or maintenance. The physiologic importance of this family of mediators is resulting from their specificity - members of the chemokine family induce recruitment of well-defined leukocyte subsets. There are two major chemokine sub-families based upon cysteine residues position: CXC and CC. As a general rule, members of the CXC chemokines are chemotactic for neutrophils, and CC chemokines are chemotactic for monocytes and sub-set of lymphocytes, although there are some exceptions. This review discusses the potential role of chemokines in inflammation focusing on the two best-characterized chemokines: monocyte chemoattractant protein-1, a CC chemokine, and interleukin-8, a member of the CXC chemokine sub-family.
\end{abstract}

Keywords: Chemokines/immunology; Cytokines/immunology; Immunity

\section{RESUMO}

Quimiocinas são uma grande família de pequenas citocinas e seu peso molecular varia de 7 a $15 \mathrm{kDa}$. As quimiocinas e seus receptores são capazes de controlar a migração e a residência de células imunes. Algumas quimiocinas são consideradas pró-inflamatórias e podem ser induzidas durante a resposta imune no sítio de infecção, enquanto outras são consideradas homeostáticas e estão envolvidas no controle da migração celular durante o desenvolvimento ou a manutenção dos tecidos. A importância fisiológica dessa família de mediadores é resultado de sua especificidade - os membros da família de quimiocinas induzem ao recrutamento de subtipos bem definidos de leucócitos. Existem duas grandes subfamílias de quimiocinas baseadas na posição dos resíduos de cisteínas: CXC e CC. Como regra geral, membros da família de quimiocinas CXC são quimiotáticos de neutrófilos, e as quimiocinas CC são quimiotáticos de monócitos e subtipos de linfócitos, apesar de existirem algumas exceções. Esta revisão discute o potencial papel das quimiocinas na inflamação focando nas duas quimiocinas mais bem caracterizadas: a proteína quimioatraente de monócitos-1, uma quimiocina CC, e a interleucina 8, uma quimiocina membro da subfamília CXC.

Descritores: Quimiocinas/imunologia; Citocinas/imunologia; Imunidade

\section{INTRODUCTION}

Chemokines constitute a large family of small cytokines and generally have low molecular weight ranging from 7 to $15 \mathrm{kDa}$. Chemokines and their receptors are able to control the migration and residence of all immune cells. Some chemokines are considered pro-inflammatory and their release can be induced during an immune response at a site of infection, while others are considered homeostatic, and are involved in the control of cells migration during tissue development or maintenance. The physiologic importance of this family of mediators is resulting from their specificity; members of the chemokine family induce recruitment of well-defined leukocyte subsets. ${ }^{(1,2)}$

Many chemokines were initially identified by subtraction hybridization as an immediate or early response genes induced by growth factors. Based on this property, it was supposed that chemokines were involved in cellular proliferation and acted as nuclear factors. However, when complete amino acid sequences were deduced, it was clear that chemokines were secretory proteins.

There are two families of chemokines based on the first cysteine residue: the family called CC chemokines (Chart 1), also known as beta-chemokines. The genes encoding the CC chemokines are located on chromosome 17. CC chemokines stimulate mainly monocytes, but also basophils, eosinophils,

\footnotetext{
'Hospital Israelita Albert Einstein, São Paulo, SP, Brazil.

${ }^{2}$ Allergy and Immunopathology Graduate Program of Faculdade de Medicina, Universidade de São Paulo, São Paulo, SP, Brazil.

Corresponding author: Luciana Cavalheiro Marti - Avenida Albert Einstein, 627/701 - Morumbi - Zip code: 05652-900 - São Paulo, SP, Brazil - Phone: (55 11) 2151-1353 - E-mail: Imarti@einstein.br

Received on: July 20, 2015 - Accepted on: Aug 18, 2015
}

DOI: 10.1590/S1679-45082015RB3438 
T-lymphocytes, and natural killer (NK) cells. The other family CXC (Chart 2), known as alpha-chemokines, have an intervening amino acid between the first two cysteines and are located in the chromosome $4 .^{(3-5)}$ These chemokines, which mainly stimulate neutrophil chemotaxis, contain a Glu-Leu-Arg (ELR) sequence in the $\mathrm{N}$-terminus that is essential for receptor binding. ${ }^{(6,7)}$

Chart 1. Chemokines: $\mathrm{CC}$, receptors and immune function

\begin{tabular}{|c|c|c|c|}
\hline Chemokine & $\begin{array}{c}\text { Other } \\
\text { names }\end{array}$ & Receptor & Immune function \\
\hline CCL1 & $1-309$ & CCR8 & Th2 and Treg trafficking \\
\hline CCL2 & MCP-1 & CCR2 & Monocyte trafficking \\
\hline CCL3 & MIP-1 $\alpha$ & CCR1, CCR5 & $\begin{array}{l}\text { Macrophage-NK migration; } \\
\text { T cell/DC interaction }\end{array}$ \\
\hline CCL4 & MIP-1 $\beta$ & CCR5 & $\begin{array}{l}\text { Macrophage-NK migration; } \\
\text { T cell/DC interaction }\end{array}$ \\
\hline CCL5 & RANTES & CCR1, CCR3, CCR5 & $\begin{array}{l}\text { Macrophage-NK migration; } \\
\text { T cell/DC interaction }\end{array}$ \\
\hline CCL6 & C-10 & Unknown & $?$ \\
\hline CCL7 & MCP-3 & CCR2, CCR3 & Monocyte mobilization \\
\hline CCL8 & MCP-2 & $\begin{array}{c}\text { CCR1, CCR2, CCR3, } \\
\text { CCR5 }\end{array}$ & Th2 response \\
\hline CCL9 & MIP-1 $\gamma$ & Unknown & $?$ \\
\hline CCL10 & MIP-1 $\gamma$ & Unknown & $?$ \\
\hline CCL11 & Eotaxin & CCR3 & $\begin{array}{l}\text { Eosinophil and basophil } \\
\text { migration }\end{array}$ \\
\hline CCL12 & MCP-5 & CCR2 & Monocyte trafficking \\
\hline CCL13 & MCP-4 & CCR2, CCR3, CCR5 & Th2 response \\
\hline CCL14 & HCC-1 & CCR1 & $?$ \\
\hline CCL15 & HCC-2 & CCR1, CCR3 & $?$ \\
\hline CCL16 & HCC-4 & CCR1, CCR2, CCR5 & $?$ \\
\hline CCL17 & TARC & CCR4 & $\begin{array}{l}\text { Th2 response, Th2 cell migration, } \\
\text { Treg, lung and skin homing }\end{array}$ \\
\hline CCL18 & PARC & CCR8 & $\begin{array}{c}\text { Th2 response, marker AAM, } \\
\text { skin homing }\end{array}$ \\
\hline CCL19 & MIP-3ß & CCR7 & $\begin{array}{l}\text { T cell and DC homing to } \\
\text { lymph node }\end{array}$ \\
\hline CCL2O & MIP-3 $\alpha$ & CCR6 & $\begin{array}{c}\text { Th17 response, B cell and } \\
\text { DC homing to gut associated } \\
\text { lymphoid tissue }\end{array}$ \\
\hline CCL21 & SLC & CCR6, CCR7 & $\begin{array}{l}\text { T cell and DC homing to } \\
\text { lymph node }\end{array}$ \\
\hline CCL22 & $\mathrm{MDC}$ & CCR4 & $\begin{array}{c}\text { Th2 response, Th2 cell migration, } \\
\text { T reg migration }\end{array}$ \\
\hline CCL23 & MIP-3 & Unknown & $?$ \\
\hline CCL24 & Eotaxin-2 & CCR3 & $\begin{array}{c}\text { Eosinophil and basophil } \\
\text { migration }\end{array}$ \\
\hline CCL25 & TECK & CCR9 & $\begin{array}{l}\text { T cell homing to gut, } \\
\text { thymocyte migration }\end{array}$ \\
\hline CCL26 & Eotaxin-3 & CCR3, CX3CR1 & $\begin{array}{c}\text { Eosinophil and basophil } \\
\text { migration }\end{array}$ \\
\hline CCL27 & CTAK & CCR10 & T cell homing to skin \\
\hline CLL28 & MEC & CCR3, CCR10 & $\begin{array}{l}\text { T cell and IgA plasma cell } \\
\text { homing to mucosa }\end{array}$ \\
\hline
\end{tabular}

Source: Murphy PM et al.(3)
Chart 2. Chemokines: $\mathrm{CXC}$, receptors and immune function

\begin{tabular}{|c|c|c|c|}
\hline Chemokine & $\begin{array}{l}\text { Other } \\
\text { names }\end{array}$ & Receptor & Immune function \\
\hline CXCL1 & $\mathrm{GRO} \alpha$ & CXCR2 & Neutrophil trafficking \\
\hline CXCL2 & GRO $\beta$ & CXCR2 & Neutrophil trafficking \\
\hline CXCL3 & $\mathrm{GRO} \gamma$ & CXCR2 & Neutrophil trafficking \\
\hline CXCL4 & PF4 & $?$ & Pro-coagulant \\
\hline CXCL5 & ENA78 & CXCR2 & Neutrophil trafficking \\
\hline CXCL6 & GCP-2 & CXCR1, CXCR2 & Neutrophil trafficking \\
\hline CXCL7 & NAP-2 & CXCR2 & Neutrophil trafficking \\
\hline CXCL8 & $\| \mathrm{L}-8$ & CXCR1, CXCR2 & Neutrophil trafficking \\
\hline CXCL9 & MIG & CXCR3 & $\begin{array}{c}\text { Th1 response, Th1, CD8 and } \\
\text { NK trafficking }\end{array}$ \\
\hline CXCL10 & IP-10 & CXCR3 & $\begin{array}{c}\text { Th1 response, Th1, CD8 and } \\
\text { NK trafficking }\end{array}$ \\
\hline CXCL11 & I-TAC & CXCR3 & $\begin{array}{c}\text { Th1 response, Th1, CD8 and } \\
\text { NK trafficking }\end{array}$ \\
\hline CXCL12 & SDF-1 & CXCR4 & Bone marrow homing \\
\hline CXCL13 & $\mathrm{BLC}$ & CXCR5 & $\begin{array}{l}\text { B cell and Tfh positioning in } \\
\text { lymph node }\end{array}$ \\
\hline CXCL14 & BRAK & $?$ & Macrophage skin homing \\
\hline CXCL15 & Lungkine & $?$ & $?$ \\
\hline CXCL16 & 5R-PSOX & CXCR6 & NKT and ILC migration and survival \\
\hline CXCL17 & $\mathrm{DMC}$ & $?$ & $?$ \\
\hline XCL1 & SCM-1 $1 \alpha$ & XCR1 & Cross-presentation by CD8+ DC \\
\hline XCL2 & SCM-1 $\beta$ & XCR2 & Cross-presentation by CD8+ DC \\
\hline CX3CL1 & Fractalkine & CX3CR1 & NK, monocyte and T cell migration \\
\hline
\end{tabular}

Chemokine receptors are differentially expressed by all leukocytes and can be divided into two groups: $G$ protein-coupled chemokine receptors, which is activated by pertussis toxin (PTX)-sentive $\mathrm{G}_{\mathrm{i}}$-type $\mathrm{G}$ protein; and an atypical chemokine receptors, which appear to form chemokine gradients and dampen inflammation by scavenging chemokines in a $\mathrm{G}$ protein independent manner. ${ }^{(8)}$

Nowadays approximately 50 endogenous chemokines ligands and 20 G-protein-coupled receptors have been described. However, there is still a lot to be comprehended in this field, particularly regarding mechanisms during diseases development. In this review, we focused on a timeline basic knowledge in chemokines.

\section{MONOCYTE CHEMOATTRACTANT PROTEIN-1 (CCL2/MCP-1) AND CC CHEMOKINES}

Acute inflammation is a complex process characterized by the coordinated migration of effector cells to the site of inflammation, as well as displacement of immune cells from peripheral sites to draining lymphoid organs to initiate immune response. Such coordinated movement 
of cells requires the induced expression of inflammatory chemokines and their respective receptors on target cells. The interaction between chemoattractant and immune cells trigger a series of biochemical and cellular coordinate events. ${ }^{(8,9)}$

CCL2 is typically secreted in two predominant forms with similar molecular weights of 9 and $13 \mathrm{kDa}$. They have the same protein core and differ by the addition of O-linked carbohydrates to the larger form. ${ }^{(10)}$ Despite this difference, they have identical activities in vitro. ${ }^{(11)}$

CCL2 stimulates chemotaxis of monocytes and several cellular events associated with chemotaxis, including $\mathrm{Ca}^{2+}$ flux and integrin expression. It is also a weak inducer of cytokine expression in monocytes and, at high concentrations, elicits a respiratory burst leading to generation of reactive oxygen species. ${ }^{(11,12)}$

Monocytes utilize different chemoattractant molecules to migrate; however, CCL2 and CCL7 are rapidly produced by stromal cells and immune cells after pattern-recognition receptors (PRR) activation or after cytokine stimulation. CCL2 dimerizes and binds to extracellular matrix glycosaminoglycans, thus establishing a stable gradient for CCR2+ inflammatory monocytes. ${ }^{(8,13)}$

CCL2 expression has been identified upregulated in certain cell types of some diseases, such as macrophages/ foam cells and smooth muscle cells in atherosclerosis; delayed-type of hypersensitivity reactions in the skin mononuclear phagocytes, endothelial cells, and keratinocytes; melanoma cells in skin cancer and synoviocites of rheumatoid arthritis..$^{(14-17)}$

Two other chemokines structurally related to CCL2 are named CCL8 (MCP-2) and CCL7 (MCP-3). Generally, CCL2 and CCL7 have similar properties, although CCL7 may exhibit characteristics from both CCL2 and CCL5 (RANTES), suggesting that it has a broader range of chemokine binding. Others $\mathrm{CC}$ chemokines include macrophage inflammatory protein $1 \alpha$ (MIP-1 $\alpha /$ CCL3), macrophage inflammatory protein$1 \beta$ (MIP-1ß/CCL4), T-cell activation gene-3 (TCA-3/ CCL1), and CCL5, which support and regulate activated T-cells. ${ }^{(12,18,19)}$

Eosinophil is a leukocyte present in high numbers during inflammatory allergic reactions, such as asthma and rhinitis; there is evidence that links accumulation and activation of these cells with tissue injury and lung dysfunction. ${ }^{(20-22)}$ Humbles et al. purified and sequenced a CC-chemokine from bronchoalveolar lavage fluid of allergen-challenged sensitized animal model. They also identified CCL11 (Eotaxin-1) as a local chemoattractant responsible for eosinophil recruitment, via CCR3, a chemokine receptor highly expressed on eosinophils. ${ }^{(23)}$
These leukocytes express CCR 1 and CCR 3 and can respond to a variety of chemokines including CCL11, CCL24 (Eotaxin-2) and CCL26 (Eotaxin-3). ${ }^{(24,25)}$

CCL19 (MIP-3 3 ) and CCL21 (SLC) are expressed mainly by stromal cells in $\mathrm{T}$ cell-rich zones of lymph nodes. They are mediators of homeostatic trafficking of naïve $\mathrm{T}$ cells, but also play a role on $\mathrm{T}$ cell priming and activation, as well as on lymphocytes recruitment to inflamed tissue. The pathway signaling of both proteins take place via CCR7, which is expressed on T cells and mature dendritic cells. Although CCL19 and CCL21 exhibit the same affinity for CCR7, only CCL19 has ability to desensitize and internalize the receptor. ${ }^{(8)}$

$\mathrm{T}$ cells and progenitor cells enter the thymus in response to CCL21/SLC and CCL25/TECK, which are produced by thymic epithelium and surrounding structures. CCR9 guides these cells to the subcapsular zone. Subsequent thymic maturation from doublepositive through single-positive thymocytes occurs in concert with their migration into the medulla, which is dependent on CCR7 and perhaps another chemokine yet to be defined. ${ }^{(26)}$

In general, chemokines CCL2, CCL3, CCL4, CCL5, CCL11 and CCL13 are classified as inflammatory; CCL18, CCL19, CCL21, CCL25 and CCL27 as homeostatic. CCL1, CCL17, CCL20 and CCL22 with dual function inflammatory and homeostatic while CCL14, CCL15, CCL16 and CCL23 are related with plasma or platelet. ${ }^{(27)}$

\section{INTERLEUKIN-8 AND CXC CHEMOKINES}

lnterleukin-8 (IL-8/CXCL8) is a prototypical member of CXC chemokine family. The IL- 8 gene encodes a 99-aminoacid translation product. It undergoes proteolytic cleavage of the amino terminal yielding several different products. IL-8 in solution is thought to exist as non-covalently linked dimer, and, in vitro, it is a potent chemoattractant for neutrophils. It has been reported to be also a chemoattractant for a subset of T-lymphocytes. ${ }^{(28)}$

IL-8 has also been named neutrophil activating protein-1 (NAP-1), since it stimulates release of neutrophil granules. Like many other chemoattractants, IL-8 induces re-arrangement of cytoskeleton, changes in intracellular $\mathrm{Ca}^{2+}$ levels, activation of integrins, exocytosis of granule proteins, and respiratory burst. ${ }^{(29)}$ There are some chronic inflammatory diseases, such as psoriasis, rheumatoid arthritis, as well as pulmonary diseases, in which IL-8 is overexpressed, and high levels of IL-8 are also seen after septic shock or systemic administration of endotoxin. ${ }^{(30-32)}$ 
Regarding other CXC-chemokines members, neutrophils are the main responsive cell type, since they express receptors CXCR1 and CXCR2, which are able to bind to CXCL1, CXCL2, CXCL5, CXCL6, CXCL7 and CXCL8. In acute inflammation initiated by bacterial invasion, neutrophils are the first cells that infiltrate into the tissue. Neutrophils play a critical role during infection control, first by their capacity of microorganism phagocytosis, and second by releasing other chemotactic mediators, such as CXCL1, CXCL8, CXCL9 and CXCL10 that recruit other leucocytes to the affected tissues. ${ }^{(33)}$

Chemokines control innate immune cell trafficking between the bone marrow, blood, and peripheral tissues during inflammation. At the same time, systemic levels of G-CSF lead to a reduction on CXCL12 production by bone marrow and decreased CXCR 4 expression by neutrophils. Release of neutrophil from bone marrow into the blood is triggered by the switch of activated receptor, from $\mathrm{CXCR} 4$ to $\mathrm{CXCR} 2 .{ }^{(8)}$

Mast cells also play an important role in acute inflammation because they express a wide variety of PRR and contain large granules of preformed inflammatory mediators. LPS stimulated murine peritoneal mast cells leads to immediate release of CXCL1- and CXCL2containing granules, but not histamine-containing granules, as well as transcriptional activation of CXCL1 and CXCL2. This promotes early neutrophil recruitment that is abolished in mast cell-depleted mice, but not macrophage-depleted mice. ${ }^{(8)}$

CX3CL1 (or fractalkine) is an atypical chemokine with a documented role in the development of numerous inflammatory diseases, including atherosclerosis. It represents the only known member of the CX3C family and was first characterized by Bazan et al. ${ }^{(34)}$ It is a unique chemotactic factor existing in both membranebound and soluble form. The human CX3CL1 molecule consists of 373 amino acids and it is functionally divided into four domains: an extracellular domain of 76 amino acids connected to an extended 241 amino acid mucinlike stalk, followed by transmembrane and intracellular domains of 21 and 35 amino acids, respectively. CX3CL1 is synthesized as a membrane-bound molecule with the chemokine domain presented on a mucin-like stalk, which mediates the direct capture of circulating leukocytes. Cleavage at the base of this stalk by a protease, namely the tumor necrosis alpha-converting enzyme, generates a soluble chemokine, which function as a potent chemoattractant of target cells. ${ }^{(34,35)}$

The fractalkine receptor CX3CR1 is a well-established marker of anti-inflammatory or patrolling monocytes known by providing pro-survival signal to anti- inflammatory monocytes, but is also present in NK cells, $\mathrm{T}$ cells, and smooth muscle cells, where it mediates migration, adhesion and proliferation. CXCR3 is also present on pro-inflammatory monocytes and may play a role on normal function of inflammatory monocytes. ${ }^{(8)}$

In general, chemokines CXCL1, CXCL2, CXCL3, CXCL5, CXCL6, CXCL7 and CXCL8 are classified as inflammatory; CXCL12 and CXCL13 as homeostatic. CXCL9, CXCL10, CXCL11 and CXCL16 with dual function inflammatory and homeostatic, while CXCL4 is plasmatic or platelet related. ${ }^{(27)}$

\section{ACKNOWLEDGMENTS}

We are grateful to Fundação de Amparo à Pesquisa do Estado de São Paulo (FAPESP) grant number 2014/15504-7 and to Sociedade Beneficente Israelita Brasileira Hospital Albert Einstein for their support.

\section{REFERENCES}

1. Oppenheim JJ, Zachariae CO, Mukaida N, Matsushima K. Properties of the novel proinflammatory supergene "intercrine" cytokine family. Annu Rev Immunol. 1991;9:617-48. Review.

2. Raz $\mathrm{E}$, Mahabaleshwar $\mathrm{H}$. Chemokine signaling in embryonic cell migration: a fisheye view. Development. 2009;136(8):1223-9. Review.

3. Murphy PM, Baggiolini M, Charo IF, Hébert CA, Horuk R, Matsushima K, et al. International union of pharmacology. XXII. Nomenclature for chemokine receptors. Pharmacol Rev. 2000;52(1):145-76. Review.

4. Luster $A D$, Ravetch JV. Genomic characterization of a gamma-interferoninducible gene (IP-10) and identification of an interferon-inducible hypersensitive site. Mol Cell Biol. 1987:7(10):3723-31.

5. Mukaida N, Shiroo M, Matsushima K. Genomic structure of the human monocyte-derived neutrophil chemotactic factor IL-8. J Immunol. 1989;143(4): 1366-71.

6. Clark-Lewis I, Schumacher C, Baggiolini M, Moser B. Structure-activity relationships of interleukin-8 determined using chemically synthesized analogs. Critical role of $\mathrm{NH} 2$-terminal residues and evidence for uncoupling of neutrophil chemotaxis, exocytosis, and receptor binding activities. J Biol Chem. 1991;266(34): 23128-34.

7. Hébert CA, Vitangcol RV, Baker JB. Scanning mutagenesis of interleukin-8 identifies a cluster of residues required for receptor binding. J Biol Chem. 1991;266(28):18989-94.

8. Griffith JW, Sokol CL, Luster AD. Chemokines and chemokine receptors: positioning cells for host defense and immunity. Annu Rev Immunol. 2014; 32:659-702. Review.

9. Murdoch C, Finn A. Chemokine receptors and their role in inflammation and infectious diseases. Blood. 2000;95(10):3032-43. Review

10. Jiang Y, Valente AJ, Williamson MJ, Zhang L, Graves DT. Post-translationa modification of a monocyte-specific chemoattractant synthesized by glioma, osteosarcoma, and ascular smooth muscle cells. J Biol Chem. 1990;265(30): 18318-21.

11. Jiang Y, Beller DI, Frendl G, Graves DT. Monocyte chemoattractant protein-1 regulates adhesion molecule expression and cytokine production in human monocytes. J Immunol. 1992;148(8):2423-8.

12. Rollins BJ, Morrison ED, Stiles CD. Cloning and expression of JE, a gene inducible by platelet-derived growth factor and whose product has cytokinelike properties. Proc Natl Acad Sci USA. 1988;85(11):3738-42. 
13. Proudfoot AE, Handel TM, Johnson Z, Lau EK, LiWang P, Clark-Lewis I, et al. Glycosaminoglycan binding and oligomerization are essential for the in vivo activity of certain chemokines. Proc Natl Acad Sci USA. 2003;100(4):1885-90.

14. Ylä-Herttuala S, Lipton BA, Rosenfeld ME, Särkioja T, Yoshimura T, Leonard EJ, et al. Expression of monocyte chemoattractant protein 1 in macrophage-rich areas of human and rabbit atherosclerotic lesions. Proc Natl Acad Sci USA. 1991;88(12):5252-6.

15. Graves DT, Barnhill R, Galanopoulos T, Antoniades HN. Expression of monocyte chemotactic protein-1 in human melanoma in vivo. Am J Pathol. 1992;140(1):9-14.

16. Villiger PM, Terkeltaub R, Lotz M. Production of monocyte chemoattractant protein-1 by inflamed synovial tissue and cultured synoviocytes. J Immunol. 1992;149(2):722-7.

17. Yu X, Barnhill RL, Graves DT. Expression of monocyte chemoattractant protein-1 in delayed type hypersensitivity reactions in the skin. Lab Invest. 1994;71(2):226-35.

18. Opdenakker G, Froyen G, Fiten P, Proost P, Van Damme J. Human monocyte chemotactic protein-3 (MCP-3): molecular cloning of the CDNA and comparison with other chemokines. Biochem Biophys Res Commun. 1993;191 (2):535-42.

19. Broxmeyer HE, Sherry B, Lu L, Cooper S, Carow C, Wolpe SD, et al. Myelopoietic enhancing effects of murine macrophage inflammatory proteins 1 and 2 on colony formation in vitro by murine and human bone marrow granulocyte/ macrophage progenitor cells. J Exp Med. 1989;170(5):1583-94.

20. De Monchy JG, Kauffman HF, Venge P, Koëter GH, Jansen HM, Sluiter HJ, et al. Bronchoalveolar eosinophilia during allergen-induced late asthmatic reactions. Am Rev Respir Dis. 1985;131(3):373-6.

21. Bousquet J, Chanez P, Lacoste JY, Barnéon G, Ghavanian N, Enander I, et al. Eosinophilic inflammation in asthma. N Engl J Med. 1990;323(15):1033-9.

22. Bradley BL, Azzawi M, Jacobson M, Assoufi B, Collins JV, Irani AM, et al. Eosinophils, T-lymphocytes, mast cells, neutrophils, and macrophages in bronchial biopsy specimens from atopic subjects with asthma: comparison with biopsy specimens from atopic subjects without asthma and normal control subjects and relationship to bronchial hyperresponsiveness. J Allergy Clin Immunol. 1991;88(4):661-74.

23. Humbles AA, Conroy DM, Marleau S, Rankin SM, Palframan RT, Proudfoot $A E$, et al. Kinetics of eotaxin generation and its relationship to eosinophil accumulation in allergic airways disease: analysis in a guinea pig model in vivo. J Exp Med. 1997;186(4):601-12.
24. Kalomenidis I, Stathopoulos GT, Barnette R, Guo Y, Peebles RS, Blackwell TS, et al. Eotaxin-3 and interleukin-5 pleural fluid levels are associated with pleural fluid eosinophilia in post-coronary artery bypass grafting pleural effusions. Chest. 2005;127(6):2094-100.

25. Pope SM, Zimmermann N, Stringer KF, Karow ML, Rothenberg ME. The eotaxin chemokines and CCR3 are fundamental regulators of allergen-induced pulmonary eosinophilia. J Immunol. 2005;175(8):5341-50.

26. Love PE, Bhandoola A. Signal integration and crosstalk during thymocyte migration and emigration. Nat Rev Immunol. 2011;11(7):469-77. Review.

27. Le Y, Zhou Y, Iribarren P, Wang J. Chemokines and chemokine receptors: their manifold roles in homeostasis and disease. Cell Mol Immunol. 2004;1(2):95-104. Review.

28. Huber AR, Kunkel SL, Todd RF 3rd, Weiss SJ. Regulation of transendothelial neutrophil migration by endogenous interleukin-8. Science. 1991;254(5028): 99-102. Erratum in: Science. 1991;254(5032):631. Science. 1991;254(5037): 1435.

29. Paccaud JP, Schifferli JA, Baggiolini M. NAP-1/L-8 induces up-regulation of CR1 receptors in human neutrophil leukocytes. Biochem Biophys Res Commun. 1990;166(1):187-92.

30. Camp R, Bacon K, Fincham N, Mistry K, Ross J, Lawlor F, et al. Chemotactic cytokines in inflammatory skin disease. Adv Exp Med Biol. 1991;305:109-18. Review.

31. Kunkel SL, Standiford T, Kasahara K, Strieter RM. Interleukin-8 (IL-8): the major neutrophil chemotactic factor in the lung. Exp Lung Res. 1991;17(1):17-23.

32. Martich GD, Danner RL, Ceska M, Suffredini AF. Detection of interleukin 8 and tumor necrosis factor in normal humans after intravenous endotoxin: the effect of antiinflammatory agents. J Exp Med. 1991;173(4):1021-4.

33. De Filippo K, Dudeck A, Hasenberg M, Nye E, van Rooijen N, Hartmann K, et al. Mast cell and macrophage chemokines CXCL1/CXCL2 control the early stage of neutrophil recruitment during tissue inflammation. Blood. 2013; 121(24):4930-7.

34. Bazan JF, Bacon KB, Hardiman G, Wang W, Soo K, Rossi D, et al. A new class of membrane-bound chemokine with a CX3C motif. Nature. 1997; 385(6617):640-4.

35. Apostolakis S, Spandidos D. Chemokines and atherosclerosis: focus on the CX3CL1/CX3CR1 pathway. Acta Pharmacol Sin. 2013;34(10):1251-6. Review. 